[Aus dem Neuen Allgemeinen Krankenhause zu Hamburg-Eppendorf.]

\title{
Ueber den sogenannten Bacillus mucosus capsulatus.
} Von

Dr. Carl Fricke, Assistenzarzt.

Die Bezeichnung „Bacillus mucosus capsulatus“ gebührt nicht ausschliesslich einer Bakterienart; sie kummt vielmehr einer Gruppe von Mikroorganismen zu, welche ihre Zusammengehörigkeit durch eine Reihe von constanten Eigenthümlichkeiten kundgeben. Ausser der ihnen mit verschiedenen anderen Bakterienarten gemeinsamen Eigenschaft der Kapselbildung sind sie dadurch gekennzeichnet, dass sie auffallend grosse, pleomorphe Stäbchen darstellen, welche keine Sporen bilden, keine Eigenbewegungen zeigen und nach der Gram'schen Methode für gewöhnlich sich nicht färben lassen; ferner haben sie die Eigenart, auf der Oberfläche der verschiedenen festen Nährböden in Gestalt von üppigen, schleimigen Auflagerungen zu wuchern, und im Gelatinestich, ohne dass jemals Verflüssigung eintritt, in mehr oder weniger ausgesprochener Weise die sogen. Nagelculturen zu formen; Thieren gegenüber zeigen sie sich pathogen, insbesondere erzengen sie bei Mäusen meist ausgesprochene Septicämie. Auf der anderen Seite lassen die einzelnen Vertreter dieser Gruppe von Kapselbacillen in die Augen fallende Verschiedenheiten von einander erkennen, die sich sowohl in cultureller als auch in thierexperimenteller Beziehung äussern.

Der Hauptrepräsentant der gevannten Bakteriengruppe ist der Bacillus pneumoniae Friedländer, welcher als ihr zuerst gekannter und am Eingehendsten studirter Vertreter bei der Differenzirung der ihm verwandten Arten als Vorbild dient. 
Carl Fricke: Über dfin sogen. Bacil lus mucosus capsulatus. 381

Das Friedländer'sche Bacterium (1), welches ursprünglich im Lungensafte einer croupösen Pneumonie gefunden und von seinem Entdecker als alleiniger Erreger dieser Krankheit proclamirt wurde, hat im Laufe der Zeit sehr viel von dieser, ihm einstmals für die menschliche Pathologie zugeschriebenen specifischen Bedeutung einbüssen müssen. In seiner Eigenschaft als Infectionsagens der croupösen Pneumonie ist es von dem Fraenkel'schen Diplococcus, mit dem es auch zur Zeit seiner Entdeckung meistentheils verwechselt wurde, fast vollständig verdrängt worden. Nach Weichselbaum (2) gelingt sein cultureller Nachweis nur in 5.5\% der Fälle von typischer croupöser Pneumonie, und Baumgarten (3) hält die Annahme für die nächstliegende, dass es auch dann nur als ein secundärer Eindringling zu betrachten sei, der von den oberen Luft- und Rachenwegen aus in den Krankheitsherd gelangte, ohne irgend welchen Einfluss auf das Entstehen oder den Verlauf des Processes auszuüben. Dieser Ansicht schliesst sich die grọsse Mehrzahl der Autoren an. Im Gegensatz dazu glauben Weichselbaum, ${ }^{1}$ Finkler ${ }^{2}$ und neuerdings Honl, ${ }^{3}$ dass der Friedländer nur selten, aber entschieden auch der Erreger der croupösen Pneumonie ist.

Galvagni (cit. in Eulenburg's Realencyclopädie, 1892, Bd. XXIV, S. 457) cultivirte ihu einmal bei einer Form von croupöser Pneumonie, welche durch das Auftreten disseminirter Herde charakterisirt war. - Terray (Ref. im Centralblatt f. Bakteriologie, 1887, Bd. II, S. 557) wies ihn in einem Falle von croupöser Pneumonie und Tuberculose im Sputum neben dem Tuberkelbacillus nach. - Prior (Münchener med. Wochenschrift, 1890, S. 233) fand ihn in einem Falle von croupöser Pneumonie bei Influenza (neben Pneumoniekokken in dem durch Punction gewonnenen Iungensaft). - Klein (Centralblatt für Bakteriologie, Bd. V, Nr. 19, S. 625) constatirte bei vier Individuen in einer Epidemie einer der gewöhnlichen eroupösen Pneumonie ähnlichen Krankheit im Sputum und im Langensafte, ebenso bei einer Lungenentzündungsepidemie unter Mäusen und Meerschweinchen einen Bacillus pneumoniae, der höchstwahrscheinlich mit dem Friedländer'schen übereinstimmte.

Entschieden häufiger als bei der Lobärpneumonie wurde das Vorkommen des Pneumobacillus bei catarrhalischen Lungenaffectionen, insbesondere bei Lobulärpneumonieen constatirt, sowohl bei den relativ selbstständigen, als bei den im Verlaufe einer Infectionskrankheit auftretenden Formen. ${ }^{4}$ In allen diesen Fällen wurde er selten allein, meist in Gesell-

1 A. a. 0.

${ }^{2}$ S. Banmgarten's Jahresbericht, 1891. Bd. VII. S. 79.

${ }^{3}$ S. Lubarsch und Ostertag. Allgemeine Pathologie und pathol. Anatomie. 1896. Bd. I. S. 656. - Nach HonI kommt der Pneumobacillus in etwa 8-10 Proc. der Fälle bei croupöser Pneumonie vor.

4 Bei den erstgenannten wurde er mehrmals nachgewiesen von Pipping (Fortschritte der Medicin, 1886, Nr. 10, S. 319), Weichselbaum (a. a. O.) und Netter 
schaft von anderen Mikroorganismen (Diplococcus Fraenkel, Streptococcus pyogenes, Staphylococcus pyogenes) angetroffen, von denen jeder für sich unter Umständen den alleinigen Bakterienbefund bei der betreffenden Erkrankung ausmachen kann. Nach der übereinstimmenden Ansicht der verschiedenen Autoren kommt dem Bacillus pneumoniae, welcher höchstwahrscheinlich aus der Mundhöhle stammt, eine ätiologisch bedeutsame Rolle bei der Entstehung der secundären Pneumonieen zu; doch ist derselbe keineswegs als ein "specifischer" Erreger dieser Krankheitsprocesse zu betrachten, welche vielmehr durch ganz verschiedenartige Mikroben verursacht werden können.

In mehreren Fällen wurde das Friedländer'sche bezw. ein ihm sehr nahestehendes Bacterium nicht nur in den Krankheitsherden der Lunge, sondern auch in den die Lungenkrankheit begleitenden Complicationen nachgewiesen ${ }^{1}$ ebenso im Auswurf bei verschiedenartigen Erkrankungen. ${ }^{2}$

(cit. nach $\mathrm{Honl}$, a. a. O, S. 656). Ferner wurde er gefunden von Jaccoud (Ref. in Ba mgarten's Jahresbericht, 1890, Bd.VI, S. 105) in einem Falle von capillärer Bronchitis bei Influenza; von Dachè (Ref. ebenda, 1890, Bd. VI, S. 111) bei Pneumonie nach Influenza; von Strelitz (Archiv für Kinderheilkunde, 1891, Bd. XIII) bei Bronchopneumonie im Anschluss an Diphtherie; bei solchen nach Masern von Mosny (Ref. im Centralblatt für Bakteriologie, 1893, Bd. XIII, S. 614) und Honl (Lubarsch und Ostertag, Allgemeine Pathologie u. pathol. Anatomie, 1896, Bd.I, S. 677). Von letzterem (a. a. 0., S. 685) konnte er ausserdem in einigen Fällen von Pnenmonia caseosa bei Diabetes nachgewiesen werden. Banti (Ref. im Centralblatt für allgem. Pathologie u. pathol. Anatomie, 1891, Bd. II, S. 106) fand in einzelnen. Fällen von katarrhalischer Pneumonie ein von ihm als Bacillus pnenmonicus capsulatus benanntes Bacterium, welches eine Varietät des Friedländer'schen zu sein scheint.

Anm. v. Besser (Ref. im Centralblatt für Bakteriologie, 1889, Bd. V, S. 714) fand den Bac. pneumon. einmal im Bronchialsecret einer Leiche in Reincultur.

1 Senger (Archiv für experimentelle Pathalogie u. Pharmakol., 1886, Bd. XX, S. 389) will dasselbe bei mehreren Fällen von croupöser Pneumonie aus der dieselbe complicirenden Pleuritis exsudativa, Meningitis, Pericarditis purul., Endocarditis ulcerosa, Nephritis parenchym. in Reincultur gewonnen haben. - Weichselbaum (Wien. med.Jahrbücher, 1886, S.483; s. auch Baumgarten's Jahresber., II. Jahrg., 1886, S. 74-77) constatirte deu Pneumobacillus ausser in der Lunge auch in dem die Pneumonie begleitenden Zellgewebsödem der Brust, der Halsregion u. s. w., den entzündlichen Ergüssen in Pleura, Pericard., Peritoneum, Meningen, im Milzsaft und im Blut. - Cohn (Berliner klin. Wochenschrift, 1892, Nr. 44) konnte ihn in einem Falle von Lungenabscess, der sich im Anschluss an eine rechtsseitige Spitzenpneumonie bildete, in Reincultur züchten.

2 Kowalski (Baumgarten's Jahresber., 1890, Bd.VI, S.91), ebenso Kruse, Pansini und Pasquale (Centralbl. $f$. Bakteriol., 1890, Bd. VII, Nr. 21) fanden es im Influenzasputum; Pansini (Virchow's Archiv 1890. Bd. CXXII, S. 424) und 
Ferner wurde er bei Pleuritis exsudativa ${ }^{1}$ im Exsudate gefunden.

Mit dem Vorkommen bei den vorgenannten Affectionen ist die Rolle des Bacillus Friedländers keineswegs erschöpft; er wurde vielmehr bei den verschiedenartigsten Erkrankungen und an den verschiedensten Localitäten ${ }^{2}$ constatirt. Aus diesen Befunden geht hervor, dass er für keine bestimmte Krankheit specifisch ist.

Auf die eitererzeugende Wirkung des Pneumobacillus machte zuerst Zaufal ${ }^{3}$ aufmerksam, der ihn im eitrigen Exsudate der Paukenhöhle fand; hier konnte er auch von anderen Autoren ${ }^{4}$ nachgewiesen werden. Ausserdem wurde er in vereinzelten Fällen von Empyem der Brusthöhle $^{5}$ und wiederholt bei Meningitis ${ }^{6}$ gefunden. Desgleichen in

Fasching (Ref. im Centralblatt für Bakteriologie, 1892, Bd. II, S. 304) im Auswurf von Phthisikern.

NB. Nach Angabe sämmtlicher neuerer Untersucher ist der Bacillus pneumoniae im pneumonischen Sputum nor ausnahmsweise zu finden.

1 Jakowski (Ref. in Baumgarten's Jahresbericht, 1892, Bd. VIII, S. 56); Dreschfeld (Fortschritte der Medicin, 1885, Bd. III, S. 389) wies bei einem Kinde, das an Meningitis, Pleuritis und Pericarditis starb, in dem Exsudate der Pleura und des Pericards dem Friedländer'schen identische Mikroorganismen nach (s. Fried. länder, Fortschritte der Medicin, 1885, Bd. III, S. 760).

${ }^{2}$ Siehe auch Etienne, Ref. im Centralblatt $f$. Bakteriologie, 1895, Bd. XVIII, S. 502 und Felorow, Ref. in Virchow's Jahresbericht, 1896, XXX. Jahrg. Bd. I, S. 244.

3 Ref. in Baumgarten's Jahresbericht. 1887. Bd. III. S. 417.

- Netter (citirt nach Miller, Die Mikroorganismen der Mundhöhle, 1892, S. 324); Kossel (Charité-Annalen, 1893, 18. Jahrg., S. 498) fand ihn unter 38 Fällen von Mittelohreiterungen bei Säuglingen $6 \mathrm{mal}$ (davon $1 \mathrm{mal}$ in Reincultur, $2 \mathrm{mal}$ neben Pseudoinfluenzabacillen, 3 mal mit Streptokokken).

s Netter (Ref. in Baumgarten's Jahresbericht, 1887, Bd. III, S. 35) fand ihn in zwei Empyemfällen; in dem einen handelte es sich um einen Pyopneumothorax in Folge von Cavernenruptur bei einem Phthisiker (im Eiter wurden ausserdem Tuberkelbacillen und Staphyloc. alb. et aur. nachgewiesen); in einem zweiten Falle, wo ein circumscriptes, in die Pleurahöhle durchgebrochenes Empyem bestand, fand er sich einzig und allein im Exsudate vor.

Létulle (Ref. in Baumgarten's Jahresbericht, 1890, Bd. VI, S. 81) cultivirte ihn aus dem Auswurf und aus dem durch Probepunction entleerten Eiter eines nach Influenza an Empyem erkrankten Mannes bei mehrmaliger Untersuchung innerhalb 14 Tagen regelmässig als ausschliesslichen Bakterienbefund.

- Babes (cit. nach Honl, s. Lubarsch u. Ostertag, Allgemeine Pathodogie und pathol. Anatomie, Bd. III, S. 551) fand ihn neben dem T.-B. bei einer taberculösen Meningitis; Mills (Ref. in Baumgarten's Jahresbericht, 1892, Bd. VII, S. 67) im Eiter einer Meningitis, die wahrscheinlich im Anschluss an Influenza aufgetreten war, in Reincultur; Netter (cit. nach Dmochowski, Centralblatt f. Bakteriologie, 1894, I, S. 581) fand ihn einmal unter 28 untersuchten Meningitiden; Pešin a und Honl (cit. nach Honl, s. Lubarsch u. Ostertag, Allgemeine Pathologie u.pathol. 
einigen Fällen von Sepsis, ${ }^{1}$ sowohl in den localen Eiterherden als auch im Blute.

Netter ${ }^{2}$ fand ihn in einem Falle von Endocarditis ulcerosa; an diesem Orte wurde er auch bei Allgemeininfectionen beobachtet. Karlinski ${ }^{3}$ wies ihn bei Eiterungen nach. - Montt-Saavedro fand ihn bei Cystitis; (einmal allein - in diesem Falle ging die Cystitis mit Gasbildung einher einmal mit Streptokokken).

Ueber das sonst noch beobachtete Vorkommen des Bacterium Friedländer bezw. der ihm ähnlichen Arten in Eiterherden u. s. w. soll weiter unten berichtet werden.

Ausser im menschlichen Körper sind derartige Kapselbacillen auch in der Aussenwelt wiederholt constatirt worden, und zwar in der Zwischen-

Anatomie, Bd. III, S. 551) constatirten ihn neben dem Bacillus pyocyaneus bei einer Meningitis, welche nach eitriger Otitis mit eitriger Periostitis und Caries entstanden war; Dmochowski (a. a. O.) konnte ihn in einem Falle vou Pneumonie mit eitriger Entzündung der Hirnhäute, eitriger Rhinitis, Empyem der Highmorshöhle und des Sinus sphenoidalis, mit Caries der Schädelknochen, Phlegmone des Gesichtes und Halses im Eiter der Hirnabscesse und der Nasennebenhöhlen fast in Reincultur nachweisen; er sieht ihn als Erreger des ganzen Processes an, welcher wahrscheinlich in Form eines Nasencatarrhs begann. - Honl (s. Lubarsch o. Ostertag, Bd. III, S. 552) fand bei der Section eines diabeteskranken Individuums eitrige Entzündungen in den Meningen, Iungen und Nieren, welche durch den Bacillus Friedländer hervorgerufen waren. Es handelte sich in diesem Falle um eine Pneumobacillaemie; Jaeger (Zur Aetiologie der Meningitis cerebrospinalis epidemica, diese Zeitschrift, 1895, Bd.XIX, S. 351) wies einmal im Meningitiseiter (neben den geradezu massenhaft vorhandenen Diploc. intracellularis) einen dem Friedl. ähnlichen Kapselbacillus nach.

${ }^{1}$ Can on (Deutsche med. Wochenschrift, 1893, S. 1038) fand einmal im Leichenblute eines Falles von Gallensteinabscessen, desgleichen in den Abscessen den Pneumobacillus in Reincultur. Einmal constatirte er bei Sepsis im lebenden Blute einen Mikroorganismus, der sich von dem Friedländer nur dureh den Mangel der Knopfbildung in der Gelatinestichcultur unterschied; die Section ergab eitrige Meningitis, aus dem Eiter wurde derselbe Bacillus in Reincultur gezüchtet, ebenso aus Blut, Jeber und Milz. - Weichselbaum (Monatsschrift für Ohrenheilkunde, 1888, Nr. 8 u. 9, S. 200) züchtete ihn bei einer, an Otitis media suppurativa sich anschliessenden, tödtlichen Allgemeininfection aus den verschiedenen Eiterherden (Rhinitis, eitrige Periostitis des Proc. mastoid., Phlegmone des M. sternocleidomast.) in Reincultur; nur in der Lange und Paukenhöhle fanden sich daneben noch andere, nicht pathogene Mikroben.

Anm. Hlava (Ref. in Baumgarten's Jahresbericht, 1893, Bd. IX, S. 320) fand ihn neben anderen Mikroorganismen im Blute und in den Organen bei Typhusexanthemkranken.

${ }^{2}$ Ref. in Baumgarten's Jahresbericht. 1889. Bd. V. S. 544.

${ }^{3}$ Centralblatt für Balcteriologie. 1890. Bd. VII. S. 29.

4 Ebenda. 1896. Bd. XX. S. 171. 
deckfüllung, ${ }^{2}$ im Boden, ${ }^{2}$ in der Luft, $^{3}$ im Staube ${ }^{4}$ und endlich im Canalwasser. ${ }^{5}$

Eine besondere Beachtung verdient das Vorkommen pneumobacillenartiger Organismen in der Mund- und Nasenrachenhöhle, einmal, weil sie hier am häufigsten beobachtet worden sind, zweitens aber, weil diese Hohlräume die gemeinsame Eingangspforte für den Verdauungstractus, die Respirationswege, die Schädelhöhle und das Gehörorgan darstellen. Der für die Pathogenese wie für die Prophylaxe der verschiedensten Krankheiten gleich wichtige Einfluss, welchen die benachbarte Mund- und Nasenhöhle auf die an den genannten Localitäten des Körpers sich abspielenden infectiösen Processe ausübt, ist in der Neuzeit durch eingehende Untersuchungen vollständig klargestellt worden. Die bisher bekannten, krankheitserregenden Keime, welche in den mit den oberen Luftwegen communicirenden Räumlichkeiten ihre pathogene Wirkung entfalten, sind in der gemeinsamen Eingangsöffnung nicht nur unter pathologischen, sonderm auch unter normalen Verhältnissen gefunden worden. So auch der Bacillus pneumoniae Friedländer.

Nach Netter ${ }^{6}$ kommt er in 4,5 Procent in der Mundhöhle der Gesunden vor. Dieser Autor ${ }^{7}$ wies ihn als der erste im Speichel nach. Ferner wurde er constatirt im Mundhöhlensecret, ${ }^{8}$ im Sputum, ${ }^{9}$ bei Angina, ${ }^{10}$ bei ulceröser Stomatitis. ${ }^{11}$

${ }^{1}$ Emmerich (Archiv für Hygiene, 1884, Bd. II, S. 117) fand im Fehlboden des Schlafsaales einer Strafanstalt, unter deren Bewohnern eine Pneumonieepidemie aufgetreten war, neben einer Anzahl verschiedener Mikroben auch den Bacillus Friedländer.

${ }^{2}$ Chrostowski u. Jakowski (Ref. im Centralblatt für Bakteriologie, 1890, Bd. VIII, S. 239) fanden ihn im Boden einer Grube. Nach dem Ausgraben derselben erkrankten in dem Hause 5 Personen an croupöser Pneumonie. Bei zweien dieser Kranken wurde im Lungensaft das Friedländer'sche Bacterium nachgewiesen.

${ }^{3}$ Pawlowsky (Berliner klin. Wochenschrift, 1885, S. 330) and Uffelmann (ebenda, 1887, S. 726).

- Solowjew (Ref. im Centralblatt für Bakteriologie, 1895, Bd. XVIII, S. 60) fand ihn mehrmals im Staube der Zeughäuser des Spitals.

5 Mori (diese Zeitschrift, 1888, Bd. IV, S. 47).

- Cit. nach Miller, a. a. O. S. 322.

7 Ref. in Baumgarten's Jahresbericht. 1887. Bd. III. S. 35.

${ }^{8}$ Rosenthal, cit. nach Abel, Die Aetiologie der Ozaena. Diese Zeitschrift. 1896. Bd. XXI. S. 132.

$\checkmark$ Siehe vorher.

to Stoos, Ref. in Schmidt's Jahrb. 1886. Bd. CCL. S. 120.

11 Bernabei (Ref. in Baumgarten's Jahresbericht, 1892, Bd.VIII, S. 67) fand ihn hier einmal zusammen mit dem Streptococcus pyogenes.

Zeitschr. f. Hyglene. XXIIr. 
Auch im Secret der Nasenhöhle bei gesunden Individuen wurde er nachgewiesen ${ }^{1}$ desgleichen bei den verschiedensten Erkrankungen der Nase. ${ }^{2}$ Vor Allem aber ist nach den zahlreichen Untersuchungen von Löwenberg, Paulsen, Abel ${ }^{3}$ u. A. bei der Rhinitis athrophicans foetida et non foetida stets eine Bacillenart rom Charakter des Pneumoniebacillus anzutreffen, welche von den genannten Autoren als der Erreger dieses weitverbreiteten Krankheitsprocesses proclamirt wird.

In den Nebenhöhlen der Nase ${ }^{4}$ konnten Friedländer'sche oder ihm nahestehende Bacillen in wiederholten Fällen beobachtet werden.

Bezüglich seines Verhaltens den Versuchsthieren gegenüber ist der echte Pneumoniebacillus nach den Angaben Friedländer's (1), welcher jedoch ausschliesslich die Injection in die Lungen anwandte, absolut pathogen für weisse Mäuse. Nach Pfeiffer (4) dagegen vermag derselbe

1 v. Besser, Ref. im Centralblatt für Bakteriologie. 1889. Bd. V. S. 714 und 1890. Bd. VII. S. 151; ebenso Ref. in Baumgarten's Jahresbericht. 1889. Bd. V. S. 550. - Babes, Centralblatt für Bakteriologie. 1887. Bd. II. S. 89.

${ }^{2}$ Dittrich (Ref. von Babes im Centralblatt für Bakteriologie, 1887, Bd. II, S. 88) fand bei zwei Fällen von Rhinosclerom dem Friedländer ähnliche Mikroben. -Weichselbaum (Ref. im Centralblatt f. Bakteriologie, 1889, Bd. V, S. 552) fand den Bacillus pneumoniae neben einer anderen Bakterienart einmal bei eitriger Entzündung der Nase und der Nebenhöhlen der Nase. - Dmochowski, a. a. O. 'Thost (Deutsche med. Wochenschrift, 1886, S.161) cultivirte einmal ans Nasensecret bei Ozaena einen in cultureller wie in thierpathogener Beziehung mit dem Friedländer'schen identischen Kapselbacillus. - Hajek (Berliner klin. Wochenschrift, 1888, S. 659) fand den Pneumobacillus wiederholt im Ozaenasecret; desgleichen bei acutem Schnupfen.

${ }^{3}$ Die Litteratur über Ozaena s. bei Abel, a. a. O. - Ferner s. Baurowicz, Ueber die Aetiologie der chron. atrophirenden Rhinitiden. Autoreferat im Centralblatt für Bakteriologie. 1895. Bd. XVIII. S. 719.

4 Dmochowski, a. a. O. - Weichselbaum, a. a. O. - v. Besser, a. a. O., fand den Friedländer neben dem Streptococcus pyogenes einmal im eitrigen Inhalt der Stirnhöhle. - E. Fraenkel (Beitrag zur Pathologie und Aetiologie der Nasennebeuhöhlenerkrankungen, Virchow's Archiv, 1896, Bd. CXLIII, S. 42) untersuchte bei 146 Leichen die Nasennebenhöhlen und fand $8 \mathrm{mal}$ einen von ihm als „Bac. mucos. capsul.“ bezeichneten Mikroorganismus. Derselbe wurde 3 mal allein, 5 mal in Gesellschaft von anderen Mikroben constatirt (Diplococcus lanceolatus, Staphyloc. pyogenes aureus, Pseudodiphtheriebacillus). Einmal war die Kieferhöhle intact, einmal zeigte nur die Wandbekleidung die Zeichen frischer Entzündung, während sich kein abnormer Inhsilt vorfand; in den übrigen sieben Fällen war ein Exsudat von verschiedenartiger Beschaffenheit vorhanden. - In einem Falle wurde im rahmig. eitrigen Exsudate der Highmorshöhle der Friedländer'sche Kapselbacillus neben dem Streptococcus pyogenes nachgewiesen. NB. Nur einmal konnte Rhinitis atrophic. foetida diagnosticirt werden. - D mochowski (Ref. in Monatsschrift für Ohrenheilkunde, 1896, XXX. Jahrg., S.39) fand bei 18 Eiterungsfällen des Antrum Highmori zweinal den Pneumobacillus. 
Mäuse bei subcutaner Infection nicht zu tödten; eine Behauptung, die von Mandry (5), wenigstens für die grosse Mehrzahl der Fälle (80 Proc.), bestātigt wird. Nach den Versuchsresultaten des letztgenannten Autors führt die Injection in die Lunge und in die Bauchhöhle bei Mäusen ausnahmslos zum Tode. Bei intraperitonealer Impfung mit dem Bacillus pneumoniae gehen Meerschweinchen, wie Friedländer selbst augiebt, nur etwa in der Hälfte der Fälle zu Grunde. Foà und Rattone ${ }^{1}$ erzeugten bei diesen Thieren durch subcutane Impfung ein entzündliches Oedem, in dem massenhafte Kapselmikroben nachzuweisen waren; Injectionen in die Bauchhöhle verursachten eine tödtliche, sero-fibrinöse Peritonitis, an die sich häufig eine Pleuritis und Pericarditis anschloss; Injection in die Nasenhöhle producirte Rhinitis und Meningitis. Weichselbaum ${ }^{2}$ rief mit dem Friedländer-Bacillus bei Thieren experimentell Endocarditis hervor; Buchner ${ }^{3}$ bewirkte durch Culturen desselben (nicht sterilisirte wie sterilisirte) subcutan bei Kaninchen und Meerschweinchen stets locale Ansammlung von Eiterkörperchen. Bei Kaninchen konnten Friedländer und die meisten übrigen Autoren ausnahmslos eine völlige Immunität gegen den genannten Mikroorganismus constatiren. A. Frä n kel, ${ }^{4}$ Weichselbaum ${ }^{5}$ und $\mathrm{Pane}^{6}$ züchteten bei croupöser Pneumonie eiven dem Friedländer'schen in jeder Beziehung ähnlichen Kapselbacillus, der sich zuweilen auch für Kaninchen pathogen erwies. Und Mandry ${ }^{7}$ fand bei seinen mit dem Pneumoniebacillus angestellten Thierversuchen, dass auch Kaninchen einer Impfung mit diesem erliegen können. Passet (6) konnte durch intraperitoneale Infection mit dem Bacterium Friedländers bei Mäusen, Meerschweinchen und Kaninchen Peritonitis erzeugen; ebenso fand er, dass Mäuse nach Inhalation, Kaninchen nach intravenöser Impfung an Septicämie zu Grunde gingen, während Mäuse, Meerschweinchen und Kaninchen bei subcutaner Inoculation keine Reaction zeigten.

Dieses wechselnde Verhalten in thierexperimenteller Beziehung beweist die Thatsache, dass die Pathogenität der bei Pneumonie isolirten Kapselbacillen keine ganz constante ist, und dass eine Verschiedenheit in der Virulenz der pneumoniebacillenartigen Mikroorganismen dem Kaninchen gegenüber nicht für die Differenzirung dieser Arten verwerthet werden kann.

${ }^{1}$ Referat im Centralblatt f. klin. Medicin, 1885, Nr, 27 und in Baumgarten's Jahresbericht. 1885. Bd. I. S. 15.

2 Monatsschrift für Ohrenheillunde. 1888. S. 200.

3 Centralblatt für Bakteriologie. 1890. Bd. VIII. S. 321.

4 Zeitschrift für klin. Medicin. 1886. Bd. IX. S. 437.

5 Ref. in Baumgarten's Jahresbericht. 1886. Bd. II. S. 76.

${ }^{6}$ Ref. ebenda. 1886. Bd. II. S. 73.

7 A. a. $O$. 
Tabelle

\begin{tabular}{|c|c|c|c|c|c|c|}
\hline $\mathrm{N}$ a m e & $\mathrm{Fandort}$ & $\begin{array}{l}\text { Wuchsthum } \\
\text { auf Agar }\end{array}$ & $\begin{array}{l}\text { im Gelatine- } \\
\text { stich }\end{array}$ & auf Kartoffel & Gasbildung & $\begin{array}{c}\text { Geruch } \\
\text { der Cultur }\end{array}$ \\
\hline $\begin{array}{c}\text { Bacillus } \\
\text { pneumoniae } \\
\text { Friedländ. } \\
\text { (1) }\end{array}$ & $\begin{array}{c}\text { Iunge } \\
\text { bei croupöser } \\
\text { Pneumonie }\end{array}$ & \begin{tabular}{|} 
sowohl bei \\
Zimmer- wie bei \\
Bruttemperatur \\
als dicker, porcel- \\
lanartig glänzen- \\
der,weisser, nicht \\
deutlich faden- \\
ziehender Belag
\end{tabular} & $\begin{array}{l}\text { typische „Nagel- } \\
\text { cultur“仿 älter. } \\
\text { Culturen leichte } \\
\text { Bräunung der } \\
\text { angrenzenden } \\
\text { Partieen der } \\
\text { Gelatine }\end{array}$ & $\begin{array}{c}\text { als weiss- } \\
\text { gelbliche, } \\
\text { feuchtglänzd., } \\
\text { etwas zähe } \\
\text { Masse }\end{array}$ & $\begin{array}{c}\text { imGelatine- } \\
\text { stich }\left(\mathbf{4}^{\circ} \%\right. \\
\text { Gelatine }) \\
\text { gering, auf } \\
\text { Kartoffel } \\
\text { lebhaft }\end{array}$ & $\begin{array}{l}\text { nachTrime. } \\
\text { thylamin } \\
\text { (Löwen- } \\
\text { berg), von } \\
\text { A bel nicht } \\
\text { beobachtet }\end{array}$ \\
\hline $\begin{array}{c}\text { Bacillus } \\
\text { pseudo- } \\
\text { pneumonicus } \\
\text { Passet (6) }\end{array}$ & Abscesseiter & desgl. & desgl. & desigl. & $\begin{array}{c}\text { niemals } \\
\text { beobachtet }\end{array}$ & $\begin{array}{l}\text { etwas } \\
\text { faulig }\end{array}$ \\
\hline $\begin{array}{l}\text { Rhino- } \\
\text { sclerom- } \\
\text { bacillus (7) }\end{array}$ & $\begin{array}{l}\text { Obere Luftwege, } \\
\text { speciell d. Nasen- } \\
\text { rachenraum, bei } \\
\text { „Rhinosclerom“" }\end{array}$ & - & - & - & - & $\begin{array}{l}\text { gelegent- } \\
\text { lich nach } \\
\text { Trimethyl- } \\
\text { amin } \\
\text { (Abel) }\end{array}$ \\
\hline $\begin{array}{l}\text { Bacillus } \\
\text { canalis } \\
\text { capsulatus } \\
\text { Mori (8) }\end{array}$ & Canalwasser & $\begin{array}{l}\text { als stark faden- } \\
\text { ziehende Masse }\end{array}$ & $\begin{array}{c}\text { Typische } \\
\text { „Nageleultur“ }\end{array}$ & $\begin{array}{l}\text { als üppige, } \\
\text { gelbl., feuchte, } \\
\text { fadenziehende } \\
\text { Auflagerung } \\
\text { m.leicht buch- } \\
\text { tigen Rändern }\end{array}$ & $\begin{array}{l}\text { reichlich } \\
\text { auf } \\
\text { Kartoffel }\end{array}$ & - \\
\hline $\begin{array}{c}\text { "Protens" } \\
\text { hominis } \\
\text { capsulatus } \\
\text { Bordoni- } \\
\text { Uffreduzzi } \\
\text { (9) }\end{array}$ & $\begin{array}{l}\text { Blut und Organe } \\
\text { zweier Individ., } \\
\text { welche an einer, } \\
\text { der sog., Hadern- } \\
\text { krankheit" sehr } \\
\text { ähnlichen Infec- } \\
\text { tionskrankheit } \\
\text { zu Grunde ge- } \\
\text { gangen waren }\end{array}$ & \begin{tabular}{|} 
als üppiger, halb- \\
durchsichtiger \\
Belag, der bei \\
- schräg erstarrtem \\
Nährboden sich \\
allmählich anf \\
dem Grunde des \\
Reagensglases \\
ansammelt
\end{tabular} & $\begin{array}{l}\text { oberflächlich } \\
\text { als perlmutter- } \\
\text { farbige, promi- } \\
\text { nente Colonie } \\
\text { (ähnlich dem } \\
\text {,Nagelkopf" des } \\
\text { Bac. Friedl.) }\end{array}$ & $\begin{array}{c}\text { als feuchte, } \\
\text { glänzende, } \\
\text { farblose Masse } \\
\text { von zäher } \\
\text { Consistenz }\end{array}$ & $\begin{array}{c}\text { nicht } \\
\text { beobachtet }\end{array}$ & $\begin{array}{c}\text { niemals } \\
\text { übel }\end{array}$ \\
\hline $\begin{array}{c}\text { Bacillus } \\
\text { capsulatus } \\
\text { Pfeiffer }(4)^{7}\end{array}$ & $\begin{array}{c}\text { Peritoneal- } \\
\text { exsudat eines } \\
\text { spontan gestor- } \\
\text { benen Meer- } \\
\text { schweinchens }\end{array}$ & $\begin{array}{c}\text { in Gestalt dicker, } \\
\text { saftiger, rein } \\
\text { weisser, faden- } \\
\text { ziehend. Bezüge. } \\
\text { Wachsthum bei } \\
\text { Bruttemperatur } \\
\text { besser als bei } \\
\text { Zimmertemperat. }\end{array}$ & $\begin{array}{c}\text { als glänzend- } \\
\text { weisse "Nagel- } \\
\text { cultur“" Keine } \\
\text { Verfärbung der } \\
\text { Gelatine }\end{array}$ & $\begin{array}{l}\text { als gelblich- } \\
\text { weisser, feucht } \\
\text { glänzender, } \\
\text { zäher, faden- } \\
\text { ziehender } \\
\text { Belag }\end{array}$ & $\begin{array}{c}\text { in hoher } \\
\text { Gelatine- } \\
\text { schicht }\end{array}$ & $\begin{array}{c}\text { nach } \\
\text { Trimethyl- } \\
\text { amin } \\
(\mathrm{K} 0 \mathrm{ck} \text { el })\end{array}$ \\
\hline
\end{tabular}

1 Annales de l'Institut Pasteur. 1894. T. VIII. S. 301.

2 Ref. in Baumgarten's Jahresbericht. 1891. Bd. VII. S. 266.

3 Diese Zeitschrift. 1896. Bd. XXI. S. 125.

4 Ref. in Banmgarten's Jahresbericht. 1893. Bd. IX. S. 549.

- Baumgarten's Mykologie. 1890. Bd.II. S.691 u. 692. - Gün ther, Bakterio-

logie. 1890. S. 203. - Heim, Lehrbuch der bakteriol. Untersuchung. 1894. S. 336. 
I.

\begin{tabular}{|c|c|c|c|c|c|c|}
\hline $\begin{array}{c}\text { Luft- } \\
\text { bedürfniss }\end{array}$ & $\begin{array}{l}\text { Kapsel- } \\
\text { bildung }\end{array}$ & Bemerkungen & weisse Mäuse & $\begin{array}{c}\text { Meer- } \\
\text { schw einchen }\end{array}$ & Tauben & Kaninchen \\
\hline $\begin{array}{l}\text { facultativ } \\
\text { anaërob }\end{array}$ & $\begin{array}{l}\text { auf künstl. } \\
\text { Nährboden } \\
\text { meist ver- } \\
\text { misst, tritt } \\
\text { bei Einfüh- } \\
\text { rung d. Cul- } \\
\text { turingeeig- } \\
\text { net. Thier- } \\
\text { körper } \\
\text { wieder auf }\end{array}$ & $\begin{array}{l}\text { Milch wird n. Lö en- } \\
\text { berg }{ }^{1} \text { und Paltauf } \\
\text { z. Gerinnung gebracht, } \\
\text { nach Abe I unverän- } \\
\text { dert gelassen., Nach } \\
\text { Den ys u. Martin } \\
\text { bringt der Pneumobac. } \\
\text { die Milch z. Th. gar } \\
\text { nicht, z. Th. nur lang- } \\
\text { sam zur Gerinnung }\end{array}$ & $\begin{array}{l}\text { verhalten sich bei } \\
\text { subcut. Impfung } \\
\text { i.d.grossen Mehr- } \\
\text { zahl der Falle re- } \\
\text { fractär, gehen bei } \\
\text { Inj. in die Bauch- } \\
\text { höhle und in die } \\
\text { Lung. ausnahms- } \\
\text { los zu Grunde. } \\
\text { Auch d. Einathm. } \\
\text { zerstäubter Cuit. } \\
\text { wirkt tödtlich }\end{array}$ & \begin{tabular}{|c|} 
intraperiton. \\
infection nur \\
in etwa der \\
Hälfte der \\
Fälle zu \\
Grunde \\
\end{tabular} & - & $\begin{array}{l}\text { Verhalten sich } \\
\text { nach den An- } \\
\text { gaben Fried- } \\
\text { länder's und } \\
\text { d. meisten üb- } \\
\text { rigen Autoren } \\
\text { stets refractär; } \\
\text { n. Weich sel- } \\
\text { baum, Pane, } \\
\text { Mandry etc. } \\
\text { erliegen siezn- } \\
\text { weilen der in- } \\
\text { travenös. Inf. }\end{array}$ \\
\hline rein aërob & desgl. & - & $\begin{array}{l}t \text { rasch bei sub- } \\
\text { cutaner u. intra- } \\
\text { peritonealer } \\
\text { Impfung, nicht } \\
\text { bei Inhalation }\end{array}$ & $\begin{array}{l}\text { f bei intra- } \\
\text { peritonealer } \\
\text { Infection. Bei } \\
\text { subcut. Impf. } \\
\text { zuweilen Ab- } \\
\text { scessbildung }\end{array}$ & - & $\begin{array}{l}\text { t bei intraven. } \\
\text { Inf. Bei intrap. } \\
\text { Impf. entsteht } \\
\text { Peritonitis, bei } \\
\text { subcutaner zu- } \\
\text { weil. Abscesse }\end{array}$ \\
\hline \multirow[t]{2}{*}{$\begin{array}{l}\text { facultativ } \\
\text { anaërob }\end{array}$} & $\begin{array}{l}\text { stets auch } \\
\text { in den }\end{array}$ & $\begin{array}{c}\text { im culturell. Verhalten } \\
\text { vom Pueumobacillus }\end{array}$ & \multirow{2}{*}{\multicolumn{4}{|c|}{$\begin{array}{c}\text { Wirkt auf Mäuse, Meerschweinchen und Kaninchen } \\
\text { ebenso wie der Friedländer'sehe Bacillus, nur } \\
\text { weniger virulents }\end{array}$}} \\
\hline & $\begin{array}{l}\text { künstlichen } \\
\text { Culturen } \\
\text { ohne Wei- } \\
\text { teres zu con- } \\
\text { statiren }^{5}\end{array}$ & $\begin{array}{l}\text { nicht sicher zu unter- } \\
\text { scheiden. } \text { Färbt sich }^{5} \\
\text { grösstenth. n. Gram; } \\
\text { (n. Palta f f ist dies } \\
\text { Verhalten durchaus } \\
\text { unzuverlässig) }\end{array}$ & & & & \\
\hline desgl. & - & - & $\begin{array}{l}\text { t ausnahmslos } \\
\text { nach subcutaner } \\
\text { Impfung (in 2- } \\
\text { 3 Tagen) }\end{array}$ & refractär & - & $\begin{array}{l}\text { Infection in } \\
\text { die Pleura- } \\
\text { höhle }\end{array}$ \\
\hline desgl. & $\begin{array}{l}\text { stets auch } \\
\text { auf künstl. } \\
\text { Nährboden } \\
\text { beobachtet }\end{array}$ & \begin{tabular}{|} 
wächst bei saurer, neu- \\
tral. od. alkal. Reaction \\
gleichm. vortheilhaft. \\
Die Fadenformen fär- \\
ben sich nach Gram \\
die in Gestalt von ein- \\
zelnen Individuen ent- \\
wickelten Culturen \\
entfärben sich rasch
\end{tabular} & $\begin{array}{l}\text { desigl. (nach } \\
1-4 \text { Tagen) }\end{array}$ & $\mid \begin{array}{c}\text { bei kleinen } \\
\text { Dosen nurvor- } \\
\text { übergehend } \\
\text { krank, † erst } \\
\text { bei sehr } \\
\text { grossen } \\
\text { Quantitäten }\end{array}$ & $\ldots$ & $\begin{array}{l}\text { wie Meer- } \\
\text { sehweinchen }\end{array}$ \\
\hline desgl. & - & - & $\begin{array}{c}\text { desgl. (in } \\
2-3 \text { Tagen) }\end{array}$ & $\begin{array}{l}\text { gegen subcut. } \\
\text { Impfung } \\
\text { refractär, } \\
\text { nach intra- } \\
\text { peritonealer } \\
\text { Infection }\end{array}$ & $\begin{array}{l}\text { wie Meer- } \\
\text { sehwein- } \\
\text { chen }\end{array}$ & $\begin{array}{l}\text { gegen subcut. } \\
\text { und intraperit. } \\
\text { Impfung re- } \\
\text { fractär, t nach } \\
\text { intravenöser } \\
\text { Einverleibung } \\
\text { grosser } \\
\text { Culturmengen }\end{array}$ \\
\hline
\end{tabular}

- Ref. in Ba umgarten's Jahresbericht. 1891. Bd.VII.S. 265. - NB. Paltauf (Ref. in Baumgarten's Jahresbericht, 1890, Bd. VI, S. 207 u. Anm., ebenda, 1892, Bd. VIII, S. 259) hält Rhinosclerombacillen und Pneumoniebacillen für verschieden.

${ }^{7}$ Mit diesem vielleicht identisch ist ein ron Jaeger (a. a. O.) im Meningitiseiter gefundener, übrigens nicht genaner beschriebener Kapselbacillus, der für Mäuse hochgradig pathogen ist. 
Tabelle

\begin{tabular}{|c|c|c|c|c|c|c|}
\hline $\mathrm{Name}$ & Fundort & Wachstbum auf Agar & im Gelatinestich & $\begin{array}{c}\text { auf } \\
\text { Kartoffel }\end{array}$ & Gasbildung & $\begin{array}{c}\text { Geruch } \\
\text { der Cultur }\end{array}$ \\
\hline $\begin{array}{c}\text { Bacillus } \\
\text { capsulatus } \\
\text { Mandry } \\
\text { (5) }\end{array}$ & \begin{tabular}{|c|} 
Tracheal- \\
und \\
Bronchial- \\
schleim
\end{tabular} & $\begin{array}{c}\text { als dicker, glatter, } \\
\text { feuchtglänzender,gelb- } \\
\text { weisser Rasen. Rasches } \\
\text { Wachsthum auch bei } \\
\text { Zimmertemperatur }\end{array}$ & $\begin{array}{l}\text { als ,Nagelcultur“ } \\
\text { (dicker, porzellanweiss. } \\
\text { Knopf). Keine Braun- } \\
\text { färbung der Gelatine }\end{array}$ & \begin{tabular}{|} 
als gelblich \\
weisser, \\
feucht- \\
glänzender, \\
porzellan- \\
artiger \\
Belag
\end{tabular} & $\begin{array}{l}\text { in Gelatine } \\
\text { nicht aus- } \\
\text { gesprochen }\end{array}$ & - \\
\hline $\begin{array}{c}\text { Bacillus } \\
\text { capsulatus } \\
\text { Kockel } \\
(10)\end{array}$ & $\begin{array}{c}\text { Leber- und } \\
\text { Nieren- } \\
\text { cysten, } \\
\text { Meningitis- } \\
\text { eiter }\end{array}$ & $\begin{array}{l}\text { als dicker, grauer, sehr } \\
\text { durchscheinender,flach } \\
\text { gewölbter Belag v. ex- } \\
\text { quisit schleimig-faden- } \\
\text { ziehender Consistenz. } \\
\text { Das Condensations- } \\
\text { wasser vom schrägen } \\
\text { Agar wird allmählich } \\
\text { so fadenziehend, dass } \\
\text { es beim Umdrehen des } \\
\text { Glases nicht austliesst. }\end{array}$ & $\begin{array}{l}\text { als typische "Nagel- } \\
\text { cultur". Bei "̈lteren } \\
\text { Culturen nur selten } \\
\text { eine kaum bemerkbare } \\
\text { Bräunung d. Gelatine }\end{array}$ & $\begin{array}{c}\text { als dicker, } \\
\text { gelblicher } \\
\text { Belag }\end{array}$ & $\begin{array}{c}\text { auf } \\
\text { Kartoffel }\end{array}$ & $\begin{array}{c}\text { nicht } \\
\text { specifisch }\end{array}$ \\
\hline $\begin{array}{c}\text { Bacillus } \\
\text { capsulatus } \\
\text { Lo eb (11) }\end{array}$ & $\begin{array}{c}\text { Hornhaut- } \\
\text { infiltrat bei } \\
\text { Kerato- } \\
\text { malacia } \\
\text { infantum }\end{array}$ & $\begin{array}{l}\text { als leicht schleimiger } \\
\text { Belag; zuerst deutlich } \\
\text { fadenziehend, später } \\
\text { nicht mehr }\end{array}$ & $\begin{array}{l}\text { oberflächlich als leicht } \\
\text { knopfförmige, grau- } \\
\text { weisse Masse. Keine } \\
\text { Verfärbg. der Gelatine }\end{array}$ & $\begin{array}{l}\text { in Gestalt } \\
\text { eines nur } \\
\text { leichtfeuch- } \\
\text { ten od.mehr } \\
\text { rahmigen, } \\
\text { hellbräunl. } \\
\text { fadenzieh. } \\
\text { Belages }\end{array}$ & i. & - \\
\hline
\end{tabular}

mit dem Bacillus Friedlän er

\section{capsulatus \\ Cohn}

(a. a. o.)

Bacillus capsulatus mucosus

Fasching

Bacillus mucosus capsulatus Paulsen

Bacillus mucosus capsulatus Abel (14) abscess

Nasenrachensecret und Phthisikersputam

Nasensecrt. bei Rhinitis atrophic., Secret bei Ozaena laryngis Nasensecret bei Ozaena simplex als üppige, grauweisse, Oberflächlich als dicke'als üppiger,

stimmt in den wichtigsten culturellen Eigenschaften mit dem von Abel eher mit dem Friedländer'schen als mit dem Pfeiffer'schen Bacillus mehr dem letzteren ähnlich rung, die allmählich d. sich üb.d.ganze Oberfl. Belag, niemals, in aromatisch Schwere folgend zum der Gelatine ausdehnt. dessen Agar und (ähnl. dem grössten Theile in die Aeltere Gelatinecultur. Farbe der Gelatine gährenden Kappe des Reagens- zeigen in der Regel eine des Nähr- nur in Malz); glases hinabsinkt. ganz geringe, diffuse, bodens geringem niemals Wächst am" üppigsten weisslicheTrübung der sehr ähn- Maasse stinkend bei etwa 37. ${ }^{\circ}$, doch auch Gelat. Niemals Braun- lich ist beobachtet bei Zimmertemperatur färbung d. Gel., manchverhältnissm. - 'schnell; mal eine geringe Bräubei Temp. anter $12^{\circ}$ nung d.eintrocknenden kein Wachsthum mehr Bacillenmassen beob.

ist dem Bacillus mucosus von Abel 
II.

\begin{tabular}{|c|c|c|c|c|c|c|}
\hline $\begin{array}{l}\text { Luftbe- } \\
\text { dürfniss }\end{array}$ & Kapselbildung & Bemerkungen & $\begin{array}{l}\text { weisse } \\
\text { Mäuse }\end{array}$ & $\begin{array}{c}\text { Meer- } \\
\text { sohweingh. }\end{array}$ & Tauben & Kaninchen \\
\hline $\begin{array}{l}\text { faculta- } \\
\text { tiv } \\
\text { anaërob }\end{array}$ & $\begin{array}{l}\text { regelmässig vorhanden } \\
\text { in den bei } 37^{\circ} \mathrm{C} \text {. ge- } \\
\text { halt. Culturen, so lange } \\
\text { diese nur wenige Tage } \\
\text { alt sind. Im Blut u. in } \\
\text { d. Urgansäften der ge- } \\
\text { impft. Thiere nie so } \\
\text { schön, wie in den Cult. }\end{array}$ & - & $\begin{array}{l}\text { t aus- } \\
\text { nahsmlos } \\
\text { nach sub- } \\
\text { cutaner } \\
\text { Impfung } \\
\text { (im Laufe } \\
\text { v. } 2 \text { Tagen) }\end{array}$ & - & refract. & $\begin{array}{l}\text { t in einem Theil } \\
\text { der Fälle b.intra- } \\
\text { venös. u. intraper. } \\
\text { Inf., anderweitig. } \\
\text { Applic. ist entw. } \\
\text { ganz unschädl.od. } \\
\text { macht die Thiere } \\
\text { nur vorübg.krank }\end{array}$ \\
\hline desgl. & $\begin{array}{l}\text { in Culturen sowohl } \\
\text { bei Brit- als auch bei } \\
\text { Zimmertemperatur; } \\
\text { besonders schön im } \\
\text { Organismus } \\
\text { der Versuchsthiere }\end{array}$ & $\begin{array}{l}\text { besitzt keinen ausge- } \\
\text { sprochenen Pleomor- } \\
\text { phismus. Wächst nicht } \\
\text { auf sauren Nährböden. } \\
\text { In Milch nur geringes } \\
\text { Wachsth.,keineGerinn. } \\
\text { Bei Uebertragung von } \\
\text { Reagensglas z. Regens } \\
\text { glas ist die schleimige } \\
\text { Consist. d. spät. Gener. } \\
\text { nicht mehr soausgespr. }\end{array}$ & $\begin{array}{c}\text { desgl. } \\
\text { (nach 18 } \\
\text { 24Stunden) }\end{array}$ & $\begin{array}{l}\text { gegen } \\
\text { subcutane } \\
\text { Impfung } \\
\text { refractär, } \\
\text { t nach } \\
\text { intraperit. } \\
\text { Infection }\end{array}$ & - & $\begin{array}{l}\text { gegen subcutane } \\
\text { Impfung refrac- } \\
\text { tär, t nach intra- } \\
\text { venöser u. intra- } \\
\text { peritonealer } \\
\text { Infection }\end{array}$ \\
\hline desgl. & - & - & $\begin{array}{l}\text { desgl. } \\
\text { (am 3. bis } \\
\text { 4. Tage }\end{array}$ & refractär & refract. & refractär \\
\hline \multicolumn{3}{|c|}{ identificirt } & $\begin{array}{l}\text { † bei } \\
\text { subcutaner } \\
\text { Impfung }\end{array}$ & $\begin{array}{l}\text { f nach } \\
\text { intraperit. } \\
\text { Injection }\end{array}$ & - & $\begin{array}{l}\text { gegen intraperit. } \\
\text { und intravenöse } \\
\text { Infection refract. }\end{array}$ \\
\hline \multicolumn{3}{|c|}{ sehr ähnlich (A bel) } & $\begin{array}{c}\text { t aus- } \\
\text { nabmslos } \\
\text { n. subcut. } \\
\text { Impfung } \\
\text { (in 48 Std.) }\end{array}$ & - & refract. & refractär \\
\hline \multicolumn{3}{|c|}{$\begin{array}{l}\text { beschriebenen überein, doch glaubt Paulsen, ihn } \\
\text { identificiren zu können, während Abel's Culturen } \\
\text { sind (Abel) }\end{array}$} & $\begin{array}{l}\text { desgl. } \\
\text { (in wenigen } \\
\text { Tagen) }\end{array}$ & refractär & $"$ & 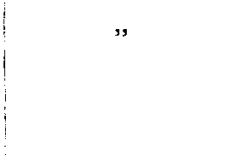 \\
\hline $\begin{array}{l}\text { faculta- } \\
\text { tiv } \\
\text { anä̈rob }\end{array}$ & $\begin{array}{c}\text { meistentheils beobach- } \\
\text { tet bei den im Körper } \\
\text { gewachsenen Bacillen; } \\
\text { in Culturen in der } \\
\text { ersten und zweiten } \\
\text { Generation nur noeh } \\
\text { gelegentlich an ein- } \\
\text { zelnen Exemplaren, } \\
\text { Ispäterhin nicht mehr, } \\
\text { höchstens noch in } \\
\text { Milchculturen }\end{array}$ & $\begin{array}{l}\text { in Milch ziemlich } \\
\text { gutes Wachsthum; } \\
\text { keine sichtbare } \\
\text { Veränderung derselben }\end{array}$ & $\begin{array}{l}\text { desgl. } \\
\text { (in } 1 \text { bis } \\
4 \text { Tagen) }\end{array}$ & $\begin{array}{l}\text { gegen } \\
\text { subcutane } \\
\text { Impfung } \\
\text { refractär, } \\
\text { t stets } \\
\text { nach intra- } \\
\text { peritoneal. } \\
\text { Injection }\end{array}$ & " & ." \\
\hline
\end{tabular}


Ta belle

\begin{tabular}{|c|c|c|c|c|c|c|}
\hline Name & Eundort & Wachsthum auf Agar & $\begin{array}{c}\text { im Gelatine- } \\
\text { stich }\end{array}$ & $\begin{array}{c}\text { auf } \\
\text { Kartoffel }\end{array}$ & $\begin{array}{l}\text { Gas- } \\
\text { bildung }\end{array}$ & $\begin{array}{c}\text { Geruch } \\
\text { der Cultur }\end{array}$ \\
\hline $\begin{array}{c}\text { Bacillus } \\
\text { capsulatus } \\
\text { von Dun-- } \\
\text { gern (15) }\end{array}$ & $\begin{array}{c}\text { Thrombosirte } \\
\text { Nabelarterie in } \\
\text { einem Falle von } \\
\text { hämorrhagischer } \\
\text { Sepsis beim Nen- } \\
\text { geborenen }\end{array}$ & $\begin{array}{l}\text { als dicker, saftiger, } \\
\text { weiss. Ueberzug. Auch } \\
\text { bei Zimmertemperatur } \\
\text { schnell vor sich gehend. } \\
\text { Einzelne Culturen zer- } \\
\text { fliessen bald rahmartig, } \\
\text { während andere sehr } \\
\text { lange Zeit fest bleiben. } \\
\text { Zuerstalkalische,später } \\
\text { unterausgesprochenem } \\
\text { Geruch nach Essigsäure } \\
\text { stark saure Reaction }\end{array}$ & - & $\begin{array}{l}\text { als sehr } \\
\text { üppiger, } \\
\text { hellgelb- } \\
\text { lich weisser } \\
\text { dichter, saf- } \\
\text { tiger, etwas } \\
\text { zäher Belag }\end{array}$ & $\begin{array}{l}\text { im Gela- } \\
\text { tinestich, } \\
\text { auf Kar- } \\
\text { toffel, in } \\
\text { Bouilion }\end{array}$ & $\begin{array}{l}\text { theils aro- } \\
\text { matisch } \\
\text { fotid, theils } \\
\text { an frisches } \\
\text { Brot erin- } \\
\text { nernd }\end{array}$ \\
\hline $\begin{array}{c}\text { Bac. capsul. } \\
\text { Marchand } \\
\text { (16) }\end{array}$ & $\begin{array}{c}\text { Exsudat } \\
\text { einer croupösen } \\
\text { Pneumonie }\end{array}$ & . & & ist in cultu & ureller Bezie & hung den \\
\hline $\begin{array}{c}\text { Bacillus } \\
\text { capsulatus } \\
\text { Nicolaier } \\
\text { (17) }\end{array}$ & $\begin{array}{c}\text { Nierenabscess } \\
\text { bei eitriger } \\
\text { Nephritis }\end{array}$ & $\begin{array}{l}\text { als üppig., weissgrauer, } \\
\text { an den Rändern hänfig } \\
\text { durchscheinender, } \\
\text { feuchtglänzender,nicht } \\
\text { fadenziehender Belag } \\
\text { v. zähflüss. Consistenz, } \\
\text { der bei aufrecht. Stel- } \\
\text { Inng des Culturglases } \\
\text { allmähl. v. d, schrägen } \\
\text { Agaroberfläche an die } \\
\text { tiefste Stelle hinab- } \\
\text { fliesst }\end{array}$ & $\begin{array}{l}\text { oberfächl. als } \\
\text { weissgraue, } \\
\text { flache, feucht- } \\
\text { glänzende, } \\
\text { zähflüss. Auf- } \\
\text { lagerung, die } \\
\text { sich meistüber } \\
\text { d. grösst. Theil } \\
\text { der Oberfläche } \\
\text { ausbreitet. } \\
\text { Keine Verfärb. } \\
\text { der Gelatine. }\end{array}$ & $\begin{array}{l}\text { als weiss- } \\
\text { graue, } \\
\text { schleimige, } \\
\text { feuchtglän- } \\
\text { zendeMasse }\end{array}$ & \begin{tabular}{|} 
auf Agar, \\
Kartoffel, \\
Trauben- \\
zucker- \\
gelatine
\end{tabular} & \\
\hline $\begin{array}{c}\text { Bacillus } \\
\text { capsulatus } \\
\text { Wicklein } \\
\text { (18) }\end{array}$ & $\begin{array}{l}\text { Chron. Leber- } \\
\text { abscess, chron. } \\
\text { eitrige. Cholecys- } \\
\text { titis mit chron. } \\
\text { diffus. Peritonitis } \\
\text { (in d. Bauchhöhle } \\
\text { eigenthümlich } \\
\text { dickschleimiges, } \\
\text { gallertartiges, } \\
\text { lediglich aus } \\
\text { Kapselbacillen } \\
\text { bestehendes } \\
\text { Pseudoexsudat) }\end{array}$ & $\begin{array}{l}\text { als massige, honigartig } \\
\text { durchscheinende, dick- } \\
\text { schleim. Auflagerung, } \\
\text { die in den nächsten } \\
\text { Tagen eine weissliche, } \\
\text { rahmartige, undurch- } \\
\text { sichtige Färbung an- } \\
\text { nimmt und zugleich } \\
\text { dünnflüssiger wird, so } \\
\text { dass sie von der schräg } \\
\text { gestellt.Agaroberfläche } \\
\text { herabfliesst, während } \\
\text { sie anfangs dem Agar } \\
\text { fest anhaftete }\end{array}$ & $\begin{array}{l}\text { oberflächlich } \\
\text { als mattweiss } \\
\text { liche Colonie }\end{array}$ & \begin{tabular}{|} 
als höch- \\
stens 2 bis \\
$3 \mathrm{~mm}$ im \\
Durch- \\
messer \\
baltender \\
dicker \\
Belag
\end{tabular} & $\begin{array}{l}\text { lebhafte in } \\
\text { hohen } \\
\text { Agar- und } \\
\text { Gelatine- } \\
\text { schichten }\end{array}$ & 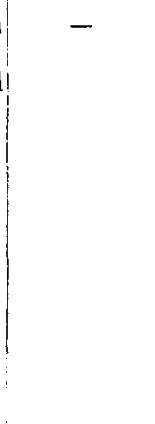 \\
\hline
\end{tabular}

Wahrscheinlich gehören zur Gruppe „Bacillus mucosus capsulatus“ auch die von Banti (eit. nach Baumgarten, Pathologische Mykologie. 1890. Bd. II. S. 865) bei einigen Krankheitsfällen beobachteten und wahrscheinlich als Erreger derselben anzusehenden pathogenen Mikroorganismen. Dieselben waren in jedem einzelnen der Fälle mehr oder weniger von einander verschieden, so dass Banti vier neue Species „capsulirter Bacillen“ aufstellte, die grosse Verwandtschạft mit dem Bacterjum Friedländer's zeigten. Sie wurden bei einer ähnlichen Krankheit, wie der Bacillus von Bordoni-Uffreduzzi, gefunden. 
III.

\begin{tabular}{|c|c|c|c|c|c|c|}
\hline $\begin{array}{l}\text { Luft- } \\
\text { bedürfniss }\end{array}$ & $\begin{array}{l}\text { Kapsel- } \\
\text { bildung }\end{array}$ & Bemerkungen & $\begin{array}{l}\text { Weisse } \\
\text { Mäuse }\end{array}$ & $\begin{array}{c}\text { Meer- } \\
\text { schweinchen }\end{array}$ & Tauben & Kaninchen \\
\hline- & - & $\begin{array}{l}\text { Milch wird bei } \\
38^{\circ} \mathrm{C} \text {. unter starker } \\
\text { Gasentwickelung in } \\
\text { 36 Stunden durch } \\
\text { Säurebildang coa- } \\
\text { gulirt. } \\
\text {. }\end{array}$ & $\begin{array}{c}t \text { aus- } \\
\text { nahmslos } \\
\text { nach sub- } \\
\text { cutaner } \\
\text { Impfong }\end{array}$ & \begin{tabular}{|c|} 
bei subcutaner \\
Impfung Tod \\
nichtregelmässig \\
erfolgend, ge- \\
wöhnl. entsteht \\
ohne Störung des \\
Allgemeinbefin- \\
dens ein Abscess \\
an der Impfstelle; \\
nach intraperito- \\
nealer Impfung \\
durchweg † in \\
18 Stunden
\end{tabular} & $\begin{array}{l}\text { bei intramus- } \\
\text { culärer Im- } \\
\text { fung refrac- } \\
\text { tär oder es } \\
\text { entsteht ein } \\
\text { Abscess an d. } \\
\text { Impfstelle; } \\
\text { n. intraperi- } \\
\text { tonealer Infec- } \\
\text { tion t nach } \\
18 \text { Stunden }\end{array}$ & $\begin{array}{l}\text { bei subentaner } \\
\text { Irapfung Tod } \\
\text { nichtregelmässig } \\
\text { erfolgend; bei } \\
\text { Inpfung in dic } \\
\text { Lunge oder in die } \\
\text { Blutbahn } \dagger \text { in } 3 \\
\text { bis } 4 \text { Tagen. - } \\
\text { Vier Kaninchen, } \\
\text { denen eine halbe } \\
\text { Platinöse Agar- } \\
\text { cultur intrave- } \\
\text { nös injicirt war, } \\
\dagger \text { in } 12 \text { bis } 18 \text { Std. }\end{array}$ \\
\hline \multicolumn{3}{|c|}{ Ozaenabacillen ähnlich } & desgl. & $t$ & 一 & \\
\hline $\begin{array}{c}\text { facultativ } \\
\text { anaërob }\end{array}$ & $\begin{array}{l}\text { inCulturen, } \\
\text { auch in den } \\
\text { ganz jun- } \\
\text { gen, nie- } \\
\text { mals beob- } \\
\text { achtet }\end{array}$ & $\begin{array}{l}\text { auf sauren Nähr- } \\
\text { böden etwas weniger } \\
\text { schnelles u. üppiges } \\
\text { Wachsthum; die Re- } \\
\text { action wird hier eine } \\
\text { alkalische. In neu- } \\
\text { trajer Lakmus- } \\
\text { bouilion wird zu- } \\
\text { nächst Säure, später } \\
\text { Alkali gebildet }\end{array}$ & $\begin{array}{c}\text { desgl. (in } \\
1 / 2 \text { bis } 41 / 2 \\
\text { Tagen) }\end{array}$ & $\begin{array}{c}\text { gegen subcutane } \\
\text { Impfung } \\
\text { refractär } \\
\text {. }\end{array}$ & - & $\begin{array}{l}\text { gegen subcutane } \\
\text { und intravenöse } \\
\text { Impfong } \\
\text { refractär. }\end{array}$ \\
\hline desgl. & $\begin{array}{l}\text { inCulturen, } \\
\text { am besten, } \\
\text { wenn diese } \\
\text { nicht über } \\
24 \text { Stunden } \\
\text { alt sind }\end{array}$ & $\begin{array}{c}\text { nach längeren } \\
\text { Uebertragungen } \\
\text { deutliche Abnahme } \\
\text { der Wachsthums- } \\
\text { energie n. vielleicht } \\
\text { auch der Virulenz } \\
\text { beobachtet; die Ba- } \\
\text { cillen wurden in den } \\
\text { späteren Cult. nie- } \\
\text { mals so gross wieAn- } \\
\text { fangs u.namentl. die } \\
\text { Bildung längerer } \\
\text { Bacillenfäden blieb } \\
\text { zuletzt ganz aus }\end{array}$ & $\begin{array}{c}\text { desgl. (in } \\
1 \text { bis } 3 \\
\text { Tagen) }\end{array}$ & $\begin{array}{l}\text { bei subcutaner } \\
\text { Impfung refrac- } \\
\text { tär, bei intraperi- } \\
\text { tonealer }+\end{array}$ & 一 & $\begin{array}{l}\text { gegen subcutane } \\
\text { und intraperi- } \\
\text { toneale Impfung } \\
\text { refractär }\end{array}$ \\
\hline
\end{tabular}

1 S. Notiz bei v. Dungern, Ueber die Hemmung der Milzbrandinfection durch Friedländer'sche Bakterien im Kaninchenorganismus. Diese Zeitschrift. 1895. Bd. XVIII. S. 180. 
Tabelle III

\begin{tabular}{|c|c|c|c|c|c|c|}
\hline Name & Fundort & $\begin{array}{l}\text { Wachsthum } \\
\text { auf Agar }\end{array}$ & im Gelatinestich & auf Kartoffel & $\begin{array}{c}\text { Gas. } \\
\text { bildung }\end{array}$ & $\begin{array}{c}\text { Geruch } \\
\text { der } \\
\text { Cultur }\end{array}$ \\
\hline $\begin{array}{c}\text { Bacillus } \\
\text { capsulatus } \\
\text { Wright u. } \\
\text { Mallory } \\
\text { (19) }\end{array}$ & $\begin{array}{l}\text { Bronchopneamon. } \\
\text { Eiter, Leberab- } \\
\text { scess a. verschie- } \\
\text { dene Organe in } \\
\text { einem Falle von } \\
\text { Septicopyämie }\end{array}$ & $\begin{array}{l}\text { als zäher, faden- } \\
\text { ziehender, durch- } \\
\text { scheinender, hell- } \\
\text { graner Belag. } \\
\text { Condenswasser } \\
\text { dick, zähe u. trïbe }\end{array}$ & $\begin{array}{l}\text { oberflächlich als } \\
\text { kleine, kugelige } \\
\text { Colonie, nur in } \\
\text { unmittelbarer } \\
\text { Umgebung der } \\
\text { Einstichstelle } \\
\text { sich verbreitend }\end{array}$ & $\begin{array}{l}\text { als dünne, zähe, } \\
\text { farblose Schicht }\end{array}$ & $\begin{array}{c}\text { zaweilen in } \\
\text { geringem } \\
\text { Maasse auf } \\
\text { schrägem } \\
\text { Agaf (mit } \\
\text { 1 Procent } \\
\text { Glucose), } \\
\text { (niemals } \\
\text { auf Kartoff., } \\
\text { Gelatine) }\end{array}$ & $\begin{array}{l}\text { nicht } \\
\text { speci- } \\
\text { fisch }\end{array}$ \\
\hline $\begin{array}{c}\text { Bacillus } \\
\text { capsulatus } \\
\text { Chiari }(20)\end{array}$ & $\begin{array}{l}\text { Eiterherde (Endo- } \\
\text { carditis, Otitis } \\
\text { media, Meningitis } \\
\text { u.s. w.) bei einer } \\
\text { Pyämie, die sich } \\
\text { aus einer ascen- } \\
\text { direnden Nephri- } \\
\text { tis suppurativa } \\
\text { entwickelt hatte }\end{array}$ & 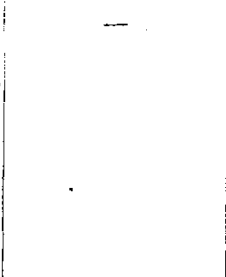 & - & - & $\begin{array}{l}\text { lebhafte, in } \\
\text { hoher } \\
\text { Zucker- } \\
\text { glycerin- } \\
\text { agarcultur }\end{array}$ & - \\
\hline
\end{tabular}

Schliesslich sei voch einiger Arten von Kapselbacillen Erwähnung gethan, welche ebenfalls zur. Gruppe „Bacillus mucosus capsulatus“ erscheint jedoch fraglich,

\begin{tabular}{c|c|c}
$\begin{array}{c}\text { Bacillus } \\
\text { crassus }\end{array}$ & $\begin{array}{c}\text { Sputum und } \\
\text { Zungenbelag }\end{array}$ & $\begin{array}{c}\text { hat mit dem Bacillus Friedländer in cultureller Beziehung die grösste } \\
\text { dadurch, dass er sich nach Gram färben lässt und bei höherer }\end{array}$
\end{tabular}

Bacillus Blut und Organe sebr schnell als NB. Die Colo- als grauweisser, |nicht vor-

buccalis ron Mäusen, die halbdurchsich- nieen auf Gela-fenchter Belag mithanden (in muciferens an einer Infection tige, schleimige tineplatten sind gezahnten Rändern, Bouillon)

Miller mit Speichel zu Masse deutlich gekörnt der in einigen Tagen

(22) Gronde gegangen und zeigen eine gelblich wird und

Krei-

bohm (21) waren

Bacillus

d. SputumAnzahl von hell-helldurchsichtig erglänzenden scheint, während die Punkten auf der Oberfläche feucht Septicämie Oberfläche bleibt.

desgl. nicht ganz so oberfächlich als als sahnefarbiger, in Bonillon sohnell als mil- halbdurchsich- feuchter, in d. Mitte beobachtet chige, grauweisse tiger Tropfen von trockener Belag, der (bei auffallendem einer pastenarti-nach den Rändern Lichte betrach- gen Consistenz zu stark gezahnt $u$. tet), weniger stark fadenziein der Farbe kaum hende Masse v. der der Kartoffel zu unterscheiden ist; nach einigen Tagen opake, glänzende, schmutzige Masse 
(Fortsetzung).

\begin{tabular}{|c|c|c|c|c|c|c|}
\hline $\begin{array}{l}\text { Iuftibe- } \\
\text { dürfniss }\end{array}$ & $\begin{array}{l}\text { Kapsel- } \\
\text { bildung }\end{array}$ & Bemerkungen & weisse Mäuse & $\begin{array}{c}\text { Meer- } \\
\text { schweinchen }\end{array}$ & Tauben & Kaninchen \\
\hline - & in Culturen & $\begin{array}{l}\text { Milch wird langsam in } \\
\text { ein zähes Coagulum u. } \\
\text { trübes Serum umge- } \\
\text { wandelt, während zu } \\
\text { gleicher Zeit die Re- } \\
\text { action sauer wird. } \\
\text { Nach Gram geht die } \\
\text { Entfärbung verhält- } \\
\text { nissmässig langsam } \\
\text { vor sich. }\end{array}$ & $t_{3 \text { Tagen) }}^{\text {(in } 1 \text { bis }}$ & $\begin{array}{l}\text { bei subcutaner } \\
\text { Impfung nur: } \\
\text { locale Eiterbil- } \\
\text { dung, bei in- } \\
\text { traperitoneal. } \\
\text { Impfung t vor } \\
\text { 24 Stunden }\end{array}$ & - & wie Meerschweinchen \\
\hline - & - & $\begin{array}{l}\text { unterscheidet sich vom } \\
\text { Bacillus pneumoniae } \\
\text { dadurch, dass er sel- } \\
\text { tener kokkenförmig er- } \\
\text { scheint, auf Blutserum } \\
\text { zarter wächst und } \\
\text { Bouillon weniger trübt }\end{array}$ & $\begin{array}{l}\text { t stets nach } \\
\text { nsubcutaner } \\
\text { wie intraperi- } \\
\text { tonealer } \\
\text { Impfung }\end{array}$ & $\begin{array}{l}f \text { nach intra- } \\
\text { peritonealer } \\
\text { Infection in } \\
\text { etwa } 12 \text { Std. }\end{array}$ & - & $\begin{array}{l}\text { bei intraperitonealer } \\
\text { Impfung nur vorüber- } \\
\text { gehend krank; gehen } \\
\text { nach intravenöser In- } \\
\text { jection rasch zuGrunde. } \\
\text { Subcutane Impfung } \\
\text { erzengt Eiterung. }\end{array}$ \\
\hline
\end{tabular}

weitgehende Aehnlichkeit mit dem Bacillus Friedländer erkennen lassen; ibre Zugehörigkeit da sie gröbere Verschiedenheiten von den Vertretern dieser zeigen:

Aehnlichkeit, unterscheidet sich von ihm vor Allem Temperatur $\left(35^{\circ}\right)$ Sporen zu bilden scheint

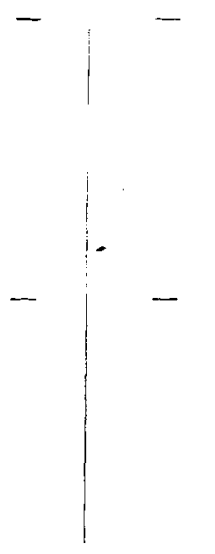

erscheint im Blute in + bei subcu-

Form von dicken, taner Impfung kurzen, gekapselten in 1 bis 3 Stäbchen, während auf Tagen; bei inkünstlichen Medien die traperitoneal.

Kokkenform vorherrscht

sehr ähnlich dem vorigen, dooh nicht identisch mit ihm

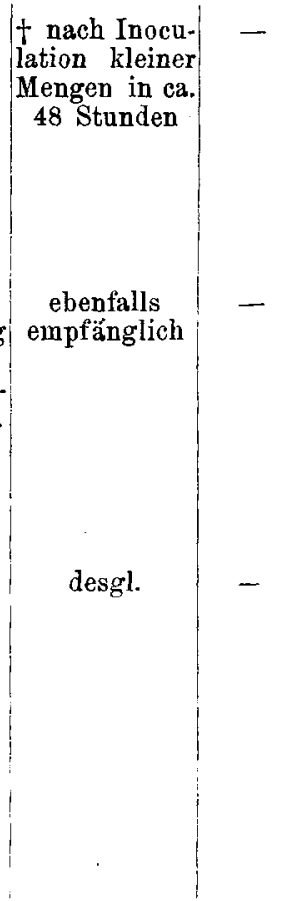

erliegen d.intravenösen Injection kleiner Dosen innerhalb 48 Std.; bei grossen Mengen erfolgt rascher Tod unter den

Erscheinungen einer acuten Gastroenteritis (noch deutlicher ist dies bei Hunden).

ebenfalls empfänglich 
Bei den mit Kapselbacillen subcutan inficirten Mäusen, welche an Septicämie zu Grunde gegangen waren, wurde von den meisten Autoren ausser einer gleichartigen Beschaffenheit der Organe (constanter, mehr oder weniger hochgradiger Milztumor; Schwellung and Hyperämie der Bauchorgane) eine eigenthümliche nekrobiotische Veränderang des Gewebes an der Impfstelle beobachtet. So fanden BordoniUffreduzzi eine ödematös-gallertartige Infiltration; Pfeiffer eine geringgradige sulzige Durchtränkung; Kockel ein geringes Oedem (oder zuweilen einen typischen Abscess mit glasig-fadenziehendem, gelb gefärbtem Inhalt); A bel ein ausserordentlich starkes Infiltrat; v. Dungern einen fibrinösen Belag; Nicolaier eine seröse Durchtränkung; Wicklein ein ausgedehntes, schleimig-gallertiges Infiltrat; Miller (Bac. buccal. mucif.) ein zähschleimiges Exsudat bezw. (Bac. der Sputum-Septicämie) ein starkes fibrinöses Exsudat und Oedem. Ausserdem konnten Pfeiffer u. Wieklein bei den der subcutanen Infeetion mit ihren Kapselbacillen erlegenen Mäusen eine fadenziehende Beschaffenheit des Blutes; Pfeiffer einen glasigen Ueberzug auf den Lungen; Wicklein einen dicklich-schleimigen Belag auf den serösen Hänten constatiren.

Die bisher in der Litteratur beschriebenen Repräsentanten der Gruppe „Bacillus mucosus capsulatus" sind in den vorstehenden Tabellen untereinander aufgeführt, mit einer kurzen Angabe des Fundortes, sowie der von den Autoren verzeichneten biologischen und thierpathogenen Eigenthümlichkeiten, durch welche sie sich, trotz der sonstigen gemeinsamen Eigenschaften, mehr oder weniger scharf von einander und vom Friedländer'schen Bacillus unterscheiden lassen.

Auf Grund der nach Durchsicht der Litteratur gewonnenen Uebersicht über das Vorkommen von Kapselbacillen der Gruppe „Bac. mucos. caps." erscheint es als feststehende Thatsache, dass diese Mikroorganismen keineswegs selten im menschlichen Organismus anzutreffen sind; sie finden sich bei den verschiedensten Krankheiten und sind bei diesen theils als Erreger, theils als mehr oder weniger nebensächliche Begleiter aufzufassen.

Im Gegensatz dazu behauptet neuerdings $A$ bel, ${ }^{1}$ welcher nach den litterarischen Notjzen das Vorkommen der pneumobacillenartigen Mikroben im Nasensecret (abgesehen von Ozaena) auf 1 Procent aller Fälle, im Mundsecret auf 2 bis 3 Procent berechnet, dass Bacillen rom Charakter des „Ozaenabacillus" in der Nasenhöhle und an den mehr oder weniger direct mit ihr in Verbindung stehenden Körperstellen (Lunge, Trachea,

1 Abel konnte die fraglichen Bacillen in der normalen Mund- und Nasenhöhle, bei acuten und chronischen Katarrhen u. s. w. der Nase, sowie im Sputum, welche er in zahIreichen Fällen culturell untersuchte, niemals nachweisen; ebensowenig gelang es u. A. Paulsen in den normalen und in den von acuten Katarrhen stammenden Secreten der Nase. 
Ohr, Schädelhöhle), welch diese Lebewesen in den meisten Fällen beherbergt haben, nur dann zu finden sind, wenn an diesen Orten selbst bezw. in ihrer Nachbarschaft ein Ozaenaprocess, gleichgültig in welchem Stadium, vorhanden ist. Dagegen konnte Abel (ebenso Löwenberg, Paulsen u. s. w.) bei Ozaena den von ihm als „Bacillus mucosus Ozaenae“ beschriebenen Mikroorganismus in zahlreichen Fällen ausnahmslos nachweisen. Derselbe fand sich bei dieser Krankheit in jungen Herden so gut wie in Reincultur; in den weiter entwickelten Stadien des Processes, wo er sich vorwiegend in den, unter den Borken liegenden weichen Secretmassen - zahlreich oder ganz vereinzelt (in mehreren Fällen konnte er nur durch das Culturverfahren nachgewiesen werden) - aufhielt, war er zumeist, besonders in den oberflächlichen Borken, mit einer Unmasse anderer Keime vergesellschaftet, und zuweilen bedurfte es wiederholter Untersuchung und häufiger, gewaltsamer Entfernung des Secrets, ehe die Cultivirung des Bacillus gelang. Der Bacillus verschwand aus der Nase, wenn der Process abheilte. Auf Grund zahlreicher und ausführlicher Untersuchungen kommt $A$ bel zu dem Schluss, dass die Ozaena eine durch den "Ozaenabacillus" erzeugte Infectionskrankheit darstellt, bei welcher der Fötor nur ein inconstantes und nebensächliches, durch die secundär sich ansiedelnden Bakterien hervorgerufenes Symptom ist. Es gelang ihm in einem Falle durch Ueberimpfung dieses Bacillus auf die Schleimhaut einer gesunden Nase, auf dieser die ersten Stadien des Ozaenaprocesses zu erzeugen. Von einem Nachweis der Bacillen in der Schleimhaut selbst wird nichts erwähnt; Versuche zur Uebertragung der Ozaena auf die Nasenschleimhaut von Thieren hatten keinen Erfolg.

In der nachfolgenden Arbeit soll nun gezeigt werden, dass pneumobacillenartige Organismen, selbst solche, welche mit dem „Ozaenabacillus“ vollständig übereinstimmen, auch bei dem völligen Fehlen eines ozaenaartigen Processes bei den versehiedensten Erkrankungen und an den verschiedensten Körperstellen gefunden werden können.

Herrn Dr. E. Fraenkel, welcher die Anregung zu dieser Arbeit gab und ihr dauernd ein grosses Interesse entgegenbrachte, sagen wir hiermit öffentlich unseren verbindlichsten Dank.

In der Zeit vom März bis zum Juni dieses Jahres wurde bei der bakteriologischen Untersuchung eines reichhaltigen Kranken- und Leichenmaterials dem Vorkommen von pneumobacillenartigen Mikroorganismen auf den mit Untersuchungsmaterial beschickten Nährböden eine specielle Aufmerksamkeit geschenkt. 
Unter 32 bakteriologisch untersuchten Fällen von Otitis media bei kindlichen Leichen, bei welchen die Section die verschiedenartigsten sonstigen Organveränderungen ergab, wurden in dem auf Glycerinagarplatten ausgestrichenen Exsudat der Paukenhöhle 13 mal Colonieen angetroffen, welche sowohl auf der Platte (üppiges, feucht-schleimig-zerfliessendes Wachsthum), wie im Deckglaspräparat (gekapselte pleomorphe Gebilde, die sich nach der Gram'schen Methode entfärbten) die grösste Aehnlichkeit mit dem Friedländer'schen Kapselbacillus zeigten. In sieben dieser Fälle, bei denen die in Frage stehenden Bacillen sich fast stets in Gesellschaft von anderen Mikroben vorfanden (nur einmal wurden sie in Reincultur angetroffen; viermal fand sich ausser ihnen der Diplococcus lanceolatus, entweder allein oder mit Pyocyaneus, Streptococcus pyogen., Staphylococcus aureus zusammen; einmal wurden sie neben Streptococcus pyogen. und Staphylococcus aureus; einmal neben Staphylococcus aureus et albus constatirt), stellten sich bei der weiteren Uebertragung von Agar auf Agar, Gelatine und Kartoffel mehr oder weniger grosse Versehiedenheiten im Wachsthum heraus, so dass eine weitere Verfolgung dieser Arten unterblieb. In den sechs übrigen Fällen fand sich fünfmal ein Kapselbacillus, der auf den verschiedensten Nährböden sowie im Thierexperiment die grösste Aehnlichkeit mit dem Friedländer'schen Bacterium darbot; einmal wurde ein Bacillus constatirt, der sich in morphologischer, cultureller und thierpathogener Beziehung als identisch mit dem bei Ozaena gefundenen Bacillus mucosus capsulatus erwies.

Zur Gruppe des Bacillus Friedländer gehörende Arten wurden ferner gefunden:

Zweimal in einer Diphtheriemembran, aus der auf Deykeagarplatte neben Diphtheriebacillen, Streptokokken und Staphylokokken zahlreiche, üppige, feucht-schleimig-zerfliessliche Colonieen gewachsen waren. Letztere, welche aus pleomorphen, nach Gram sich entfärbenden Kapselbacillen bestanden, fanden sich in dem einen Falle auch im eitrigen Exsudat der Kieferhöhlen neben Staphylococeus aureus et albus. Bei der Fortzüchtung zeigten sie jedoch gröbere Unterschiede vom Friedländer, weshalb eine weitere Untersuchung dieser Art unterblieb;

einmal (unter mehreren Fällen) im Kieferhöhlenempyem;

einmal im Bronchialschleim und gleichzeitig in den Auflagerungen bei Endocarditis ulcerosa. Der in diesem Falle gezüchtete Bacillus stimmt mit dem bei Ozaena sich findenden vollständig überein; er wurde unter etwa zehn Fällen von productiver, mit oder ohne ulcerative Processe einhergehender Endocarditis nur dieses eine Mal gefunden. 
Schliesslich wurden zur Gruppe des Bacillus pneumoniae gehörende Mikroorganismen im Stuhlgang bei Enteritis bezw. Gastroenteritis acuta (fünfmal) und im Dünndarminhalt bei Pädatrophie (einmal, hier zugleich im Paukenhöhleneiter) angetroffen.

\section{A. Kapselbacillen in der Paukenhöhle.}

Fall 1. Leptin, männl., 1/2 Jahr alt. Section am 27./III. 1896. Anatomische Diagnose: Pädatrophie; Operationswunde in der linken Axilla; Hautulcera am Hinterhaupt. Otitis media duplex. Im dünneitrigen Secret der Paukenköhle mikroskopisch ausser zahlreichen Leukocyten Diplokokken, zum Theil kurze Ketten bildend (Gram'sche Färbung positiv), mässig reichliche grosse, ovale und rundliche Gebilde mit deutlicher Kapsel (nach Gram Entfärbung); auf Glycerinagarplatte nach 24 Stunden bei $37^{\circ} \mathrm{C}$. Streptokokken, Diplococcus lanceolatus und zahlreiche erbsengrosse, rundliche, tropfenartige, grauweissliche, feucht-schleimige, zum Theil confluirte Colonieen (Bac. mucosus capsulatus I).

Fall 2. Eichbaum, männlich, 4 Monate alt. Section am 31./III. 1896. - Anatomische Diagnose: Pädatrophie; Soor in Mundhöhle und Oesophagus; Enteritis follicularis; Atelektasis und Emphysema pulmonum; Kryptorchismus. Otitis media duplex. Im schleimig-eitrigen Secret des Mittelohres mikroskopisch vorwiegend grosse rundliche und ovale Gebilde mit deutlicher Kapsel; daneben Diplokokken, zum Theil kurze Ketten bildend. Auf Glycerinagarplatte nach 24 Stunden bei $37^{\circ} \mathrm{C}$. zahlreiche saftige, rundliche, tropfenartige Colonieen von mattweisslicher Farbe (Bac. mucos. capsulat. II); zwischen diesen feinste Colonieen von Diplococcus Fraenkel.

Fall 3. Johst, weiblich, 1 Jahr alt. Section am 4./IV. 1896. Anatomische Diagnose: Pyämie; Hydrocephalus internus; Pleuritis adhaesiva duplex; Atelektasis pulmon.; Bronchitis acuta; Dilatatio et Myodegeneratio adiposa cordis; Otitis media duplex. Das dünnschleimig-eitrige Secret zeigt mikroskopisch vorwiegend Diplokokken, ferner grosse rundliche und stäbchenartige Gebilde, zum Theil mit einer Kapsel versehen; auf Glycerinagarplatte nach 24 Stunden bei $37^{\circ} \mathrm{C}$. zahlreiche Colonieen von Diplococeus Fraenkel und ziemlich reichliche erbsengrosse, rundliche, flachtropfenartige Colonieen von mattweisslicher Farbe und feuchtschleimiger Beschaffenheit (Bac. mucosus capsulat. III).

Fall 4. Möller, weiblich, $1 / 2$ Jahr alt. Section am 4./IV. 1896. Anatomische Diagnose: Rachitis; Spasmus glottidis; Atelektasis pulmon.; Otitis media dextra. Mikroskopisch ist im anscheinend reinschleimigen Secret ausser mässig reichlichen Leukocyten nichts erkennbar. Auf Glycerinagarplatte werden nach 24 Stunden bei $37^{\circ} \mathrm{C}$. zahlreiche Colonieen von Streptococcus pyogen. und vereinzelte saftige, mattweissliche Colonieen (Bac. mucos. capsul. IV) sichtbar.

Fall 5. Brammer, männlich, 4 Jahre alt. Section am 23./V. 1896. - Anatomische Diagnose: Ausgedehnte Verbrennung II. Grades. Hämorrhagieen auf den Schleimhäutnn; acute parenchymatöse Nephritis. In der 
linken Paukenhöhle schleimig-eitriges, etwas fadenziehendes Secret. Rechte Paukenhöhle und beide Highmorshöhlen leer. Auf der Nasenschleimhaut, welche im Uebrigen keincrlei Veränderungen zeigt, missfarbenes, zähschleimiges, glasiges Secret. Im Nasenschleim mikroskopisch sehr grosse ovale und rundliche Gebilde, hier und da kürzere und längere plumpe Stäbchen, auch kleinere kokkenartige Formen. Auf Glycerinagarplatte (24 Stunden bei $37^{\circ}$ C., sowie mehrere Tage bei Zimmertemperatur gehalten) nur Pyocyaneus. Im Paukenhöhleneiter mikroskopisch ziemlich reichliche Leukocyten und sehr zahlreiche Mikroorganismen (kleine und grössere Diplogebilde; grosse rundliche, ovale und ausgesprochen stäbchenartige Formen - alle mit deutlicher Kapsel versehen); auf Glycerinagarplatte üppige, ausgesprochen schleimig-zerfliessende, fadenziehende, glasige Colonieen in überwiegender Mehrzahl (Bac. mucos. capsul. V). Dazwischen Diplococcus lanceolatus und Pyocyaneus.

Fall 6. Anthes, weiblich, 6 Jahre alt. Section am 18./VI. 1896. Anatomische Diagnose: Peritonitis, Pleuritis, Pericarditis purulenta; Bronchopneumonie; Otitis media duplex. Im eitrigen Exsudat der Bauchböhle fand sich im Deckglaspräparat und auf Agarplatte der Fraenkel'sche Diplococcus in Reincultur. Im reichlichen reineitrigen Secret des Mittelohres zahlreiche Leukocyten, sehr zahlreiche Diplogebilde mit schöner, breiter Kapsel; dazwischen ziemlich schlanke, leicht gekrümmte Stäbchen. Auf Glycerinagarplatte ausser vereinzelten Colonieen von Staphylococcus aureus und einer nicht näher bestimmten Stäbchenart, zahlreiche üppige, feucht-zerfliessliche Colonieen (Bac. mucos. capsul. VI).

\section{B. Kapselbacillen im Darm.}

Fall 7. Eichbaum, s. Fall 2. Aus dem gelblichen, stark schleimhaltigen Inhalt des unteren Duodenums und Ileums wurde auf schwachsaurer Kartoffelsaftgelatine ausser Bacterium coli und Soor ein pleomorpher Bacillus gezüchtet, der auf Agar üppiges, feucht-schleimiges Wachsthum zeigte (Bac. mucos. capsul. VII).

Fall 8. Richter, 33 Jahre alter, kräftiger, früher stets gesunder Arbeiter, welcher am 10./III. 1896 plötzlich ohne nachweisbare Ursache an Durchfall, heftigen Leibschmerzen, Appetitlosigkeit erkrankte. Kein Fieber. Am 13./III. Stuhl dünnflüssig, schmutziggraugelblich, mit Sehleimfetzen vermischt. Deutlich saure Reaction, schwach säuerlicher Geruch. Im Deckglaspräparat mannigfache Formen; vorwiegend gerade, plumpe Stäbchen. Auf Gelatineplatten nach 24 Stunden bei $22^{\circ} \mathrm{C}$. ausser Proteus vulgaris (nur auf der aus der ersten Verdünnung angelegten Platte vorhanden) und Bact. coli sehr zahlreiche, saftige, tropfenartige, grauweissliche Colonieen, die auf Agar üppiges, feucht-schleimig-zerfliessliches, grauweisslich-glasiges Wachsthum zeigten und aus pleomorphen, zum Theil gekapselten Baoillen bestanden (Bac. mucos. capsulat. VIII). — Am 20./III. Stuhl wieder normal; völliges Wohlbefinden.

Fall 9. Schoof, 48jähriger, kräftiger Arbeiter; seit vier Wochen ziehende Schmerzen im Leibe, seit 14 Tagen Durchfall und Erbrechen. 
NB. Patient arbeitete zuletzt in einer Farbenfabrik und hatte mit Blei zu thun. - Am 18./V. Zunge stark belegt; Appetitlosigkeit; Leib druckempfindlich. Kein Fieber. Stuhlgang häufig, dünnflüssig, von fäculenter Beschaffenheit; reichliche Schleimbeimengung; Reaction alkalisch. Mikroskopisch mannigfache Formen, vorwiegend plumpe Stäbchen. Auf Gelatineplatten hauptsächlich Bact. coli; daneben wenig zahlreiche Colonieen von Bac. mucos. capsulat. IX. - Am 19./V. Stuhl breiig; am 23./V. geformt; Wohlbefinden.

Fall 10. Gehrke, 50jährige Frau, erkrankte nach Genuss von Buttermilch an Leibschmerzen, Erbrechen und Durchfall. Leib anfgetrieben. Am 15./VI. Stuhl dünnflüssig, graubräunlich, mit Kothpartikeln vermischt; reichliche Schleimbeimengung. Alkalische Reaction, fäculenter Geruch. Mikroskopisch sehr mannigfache Formen (vorwiegend gerade, plumpe Stäbchen). Auf Gelatineplatten ausser vereinzelten Colonieen von Bact. coli vornehmlich Proteus vulgaris. Auf Glycerineagarplatten (Ausstrich aus Peptonwasser, theils nach einfacher Aufschwemmung, theils nach 6 stündiger „Anreicherung") reichliches Wachsthum von Bac. mucos. eapsulat. X. - Am 18./VI. Stuhl normal; keine Krankheitserscheinungen.

Fall 11. Pahl, 54jähr. Schiffer, erkrankte nebst Frau und sechs Kindern nach Genuss von roher Mileh an heftigem Brechdurchfall. Am 18./VI. Stuhl trübgelblich, dünnflüssig, mit Kothpartikelchen untermischt; ziemlich reichliche Schleimbeimengung, reichlich schmutzig hellgelblicher, feinkörniger Bodensatz; fäculenter Geruch. Reaction alkaliscb. Im mikroskopischen Präparat enorm reichliche und mannigfache Bakterienformen; vorwiegend auffallend grosse, ovale und stäbchenartige Gebilde, häufig paarig liegend und mit deutlicher, breiter Kapsel versehen. Auf Gelatineplatten Bact. coli und Bac. mucos. capsulat. XI. Auf Glycerinagarplatten (Ausstrich aus Aufschwemmung und "Anreicherung" in Peptonwasser) desgleichen; nach 48 Stunden hat der Mucosus das Bact. coli völlig überwuchert. - Am 21./VI. Patient gesund.

Fall 12. Pahl, 29jähr. Frau des Vorigen. Stuhl wie vorher. Im Deckglaspräparate auffallend ähnliches Bild, auch hier zahlreiche Kapselbacillen. Auf Gelatineplatten Bact. coli, Bac. mucos. capsulat. XII und Proteus vulgaris. Auf Agarplatten (Ausstrich aus Peptonwasser nach Aufschwemmung bezw. "Anreicherung") Bact. coli und "Mucosus" zu gleichen Theilen, letzterer schnell ersteren überwuchernd. - Am 23./VI. Patientin wieder hergestellt.

\section{An anderen Orten gefundene Kapselbacillen.}

Fall 13. Tiedemann, weiblich, 16 Jahre alt. Seotion am 11./V. 96. Anatomische Diagnose: Endocarditis ulcerosa recens et inveterata. Affectio apicis dextr. pulmon. tubere. sanata. Tuberculosis glandul. lymphat. intern. Degeneratio caseosa tubercul. glandul. suprarenal. utriusque. Color fusca integumenti. (Klinisch: Morbus Addisoni). Das die Bronchien erfüllende, zähschleimige Secret wird auf Glycerineagarplatte ausgestrichen. Auf dieser sind nach 24 stündigem Aufenthalte im Brutkasten ausser zahlreichen Colonieen von Diplococcus Fraenkel und vereinzelten von Staphylococcus aureus, alles überwuchernd, zahlreiche grosse, rundliche, zum Theil confluirte, glasige, 
feuchtschleimig-zerfliessende, fadenziehende Colonieen zu erkennen. Letztere werden von grossen, pleomorphen, mit deutlicher Kapsel versehenen und in Haufen beisammenliegenden Stäbchen gebildet (Bac. mucos. capsul. XIII). Aus der Tiefe der endocarditischen Auflagerung steril entnommenes Material wird auf Glycerinagarplatte verrieben. Nach 24 Stunden bei $37^{\circ} \mathrm{C}$. sind auf derselben vorwiegend Staphylokokken und spärliche Colonieen eines mit dem aus Bronchialschlein gezüchteten identischen Kapselbacillus zur Entwickelung gelangt.

Fall 14. Balcolm, Neger, 30 Jahre alt. Section am 17./V. 96. Anatomische Diagnose: Typhus abdominalis; Icterus; Nephritis parenchym. acuta. Empyema antri Highmori sinistri (reichliches, reineitriges Exsudat). Ausstrich des Eiters auf Glycerineagarplatte; nach 24 Stunden bei $37^{\circ} \mathrm{C}$. zahlreiche Colonieen von Diplococcus lanceolatus und Staphylococcus aureus (etwa zu gleichen Theilen); 20 stecknadelkopf- bis kleinlinsengrosse, flachtropfenartige, grauweissliche Colonieen (kurze, lebhaft bewegliche Stäbchen, die sich nach Prüfung auf den verschiedenen Nährböden als Typhusbacillen erweisen. Die Anwendung der van Ermengem'schen Geisselfärbungsmethode ergiebt das Vorhandensein zahlreicher Geisseln); inmitten der übrigen drei üppige, mattweisslich-glasige, feucht-schleimig-zerfliessliche, fadenziehende Colonieen (mikroskopisch grosse pleomorphe Gebilde, meist zu zwei liegend, mit deutlicher, breiter Kapsel; sie bilden Haufen und sind stets durch grössere Zwischenräume - der Breite der Kapsel entsprechend von einander getrennt) - Bac. mucos. capsulat. XIV.

In allen den angeführten Fällen, in denen Kapselbacillen der Gruppe „Bac. muc. capsulat." gezüchtet sind, wurde sorgfältig auf das etwaige Vorhandensein eines Ozaenaprocesses geachtet; in keinem Falle konnte ein solcher constatirt werden.

In morphologischer Beziehung lassen die an den verschiedenen Localitäten gefundenen Bacillen keine bemerkenswerthen Unterschiede erkennen. Im hängenden Tropfen untersucht, erweisen sie sich sämmtlich als unbeweglich; nach der Gram'schen Methode entfärben sie sich schnell und constant. Sporenbildung wurde in keinem Falle beobachtet. In den direct aus dem Körpermaterial hergestellten Deckglaspräparaten stellen sie auffallend grosse, plumpe Stäbchen mit abgerundeten Enden und von sehr variabler Form und Länge dar. Rundliche und ovale, kokkenähnliche Gebilde, deren länge die Breite nur ganz wenig übertrifft, wechseln mit kürzeren und längeren Stäbchen ab. Selten werden längere, ungegliederte Fäden beobachtet, die entweder nur einfach gebogen oder in Zickzackform mit abgerundeten Curven gekrümmt sind. Häufig hängen die Bacillen mit den Enden paarig oder zu drei und vier Exemplaren an einander. Liegen sie in grösseren Haufen zusammen, was besonders bei Züchtung auf Agar zu beobachten ist, so berühren sich ihre Breitseiten niemals, sondern bleiben stets durch einen grösseren Zwischenraum von einander getrennt. Bei der Anordnung in Haufen fällt zuweilen eine eigenthümlich 
kantige und eckige, würfelartige Form der kokkenähnlichen Gebilde auf. - Fin charakteristischer Bestandtheil der Bacillen ist die Kapsel, die jedoch ohne Weiteres nur bei den im lebenden Körper gewachsenen Individuen sichtbar ist. Ganz besonders schön kommt sie im Blute der Maus zur Ausbildung. In Culturen lassen die Bacillen meist nur in der ersten Generation, hier entweder an zahlreichen oder auch nur an vereinzelten Exemplaren, eine deutliche Hülle erkennen; bei der zweiten Uebertragung erscheinen sie ausnahmsweise und nur hier und da mit einer Kapsel umgeben. Doch wurde mitunter sogar nach wochenlangen Uebertragungen in den auf Agar gewachsenen Culturen, sowohl den 24 stündigen, als auch den mehrere Tage alten, selbst wenn diese bei Zimmertemperatur gezüchtet waren, entweder bei der Mehrzahl der Bacillen oder nur bei einem kleineren Theile deutliche Kapselbildung beobachtet. In Milch konnte häufiger auch nach längerer Fortzïchtung der Bakterien das Vorhandensein einer Kapsel constatirt wẹrden.

Die Breite der Kapsel übertrifft hänfig die des Bacillus um das Doppelte; in ihrer Form ist sie der des Bacteriums ähnlich, also rundlich, oval oder langgestreckt elliptisch. Nicht selten liegen mehrere Gebilde in einer gemeinsamen Kapsel. Ihr Contour ist meist deutlich erkennbar, gewöhnlich erscheint. er leicht uneben. Zuweilen ist die Kapsel entsprechend der Stelle, wo paarig auftretende Stäbchen an einander liegen, etwas eingeschnürt oder sie hat eine leicht gebogene Form und umgiebt dann ein ebenso gestaltetes Bacillenpaar, dessen Trennungsgrenze eventuell kaum erkennbar ist. In der unmittelbaren Umgebung der Bacillen findet sich zumeist (vornehmlich im Blute der geimpften Thiere) ein schmaler, stark lichtbrechender Hof, und erst nach aussen von diesem erscheint dann die eigentliche Kapsel. Der Bacillus ist leicht tingirbar mit den wässerigen Lösungen der gebräuchlichen Anilinfarben. Deckglaspräparate, minutenlang mit verdünntem Carbolfuchsin in der Kälte behandelt, in Wasser abgespült und in diesem untersucht, lassen Bacillen und Kapsel deutlich gefärbt erkennen.

Ueberhaupt ist diese Besichtigung im Wasser, welche im hiesigen Institut bei der Untersuchung von Bakterienpräparaten stets geübt wird, ganz vorzüglich für die Beurtheilung der morphologischen Verhältnisse geeignet. Denn während der Zellleib durch die gewöhnlichen Einbettungsmittel, wie Canadabalsam, Cedernöl u. s. w. mehr oder weniger stark beeinflusst wird, erscheint er im Wasser in seiner natürlichen Grösse und Form, und vor Allem lässt sich in diesem Medium das Vorhandensein einer Kapsel am sichersten constatiren, ihre Gestalt und Umrisse am Naturgetreuesten erkennen. Freilich ist diese Methode nur für Augenblickspräparate verwendbar, da ja die Hülle durch längere Einwirkung des Wassers zum Verschwinden gebracht wird. 
Die Züchtung der gefundenen Kapselbacillen auf den gebräuchlichen Nährböden lässt eine frappante Aehnlichkeit des Wacbsthums in den meisten Culturmedien erkennen, aber auch vor Allem durch ihre Constanz bemerkenswerthe Differenzen, welche zu einer Trennung der Arten in Gruppen auffordern. Während die Mehrzahl ein auf den versehiedensten Züchtungsmitteln durchaus gleiches Verhalten zeigt, so dass die hierher gehörigen Arten als in cultureller Beziehung identisch bezeichnet werden müssen, bieten andere geringe Verschiedenheiten auf dem einen, sehr auffallende auf dem anderen Nährboden dar. Zu letzterem gehört vorzugsweise die Kartoffel, welche das Hauptdifferenzirungsmittel der in Frage kommenden Arten darstellt. Als Vergleichsobjecte für die Beurtheilung des culturellen Verhaltens unserer Kapselbacillen dienten die nachfolgenden Vertreter der Gruppe „Bacillus mucosus capsulatus":

1. Der Mucosus 69, von E. Fraenkel aus Kieferhöhlenexsudat ge-

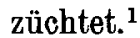

2. Drei aus Ozaenasecret isolirte Mucosusarten. Die eine, aus dem Jahre 1895 stammende Cultur wurde uns von Herrn Dr. E. Fraenkel zur Verfügung gestellt; die beiden anderen wurden aus der Nase einer Patientin, welche auf der hiesigen chirurgischen Abtheilung in Behandlung war, gezüchtet und zwar einmal im März dieses Jahres kurz nach der Aufnahme ins Krankenhaus, zum zweiten Male im Juni dieses Jahres nach längerer Behandlung der Nase mit antiseptischen Ausspülungen (2 prve. Borsäurelösung).

3. Der Bacillus pneumoniae Friedländer, theils aus dem Král'schen Laboratorium stammend (als ,authentisch" bezeichnet), theils von uns aus normalem Nasensecrete $\left(2\right.$ mal) gezüchtet. ${ }^{2}$

4. Der Bacillus capsulatus Pfeiffer (aus dem Král'schen Laboratorium stammend).

Eine vergleichende Untersuchung dieser und der von uns gefundenen Kapselbacillen führte zur Aufstellung zweier Gruppen, welche die in cultureller Beziehung am meisten zusammengehörigen bezw. identischen Arten umfassen:

'Vgl. Virchow's Archiv, a. a. O.

2 In 40 Fällen (bei 30 Erwachsen und 10 Kindern) von Secretuntersuchungen der normalen oder leicht katarrhalisch afficirten Nase haben wir zweimal einen Kapselbacillus vom Charakter des Bacillus Friedländer cultivirt. In beiden Fällen ergab die Exploration völliges Intactsein der Nasenschleimhant. Die Untersuchung des Secretes geschah in der Weise, dass ein in die Nasenhöhle eingeführter Wattetampon, nach minutenlangem Aufenthalt daselbst, entfernt und auf Glycerinagarplatten ausgestricben wurde. 
Gruppe I Bac. pneumoniae Friedländer (I, II und III), , capsulat. Pfeiffer,

" mucos. capsul. (I bis IV, VI, VII, IX bis XII),

Gruppe II Bac. mucos. capsul. aus Ozaenasecret (I, II und III), $" \quad, \quad$ " $69 ; \mathrm{V}$, XIII.

In der Mitte zwischen beiden stehen die Mucosusarten VIII und XIV.

Zu der angegebenen Gruppirung der Bacillen berechtigt ihr differentes Verhalten in der Kartoffelcultur; aber auch nur diese ermöglicht eine scharfe Trennung der Arten. Im übrigen zeigt das Verhalten auf den verschiedenen Nährböden zwar auch bei der einen oder der anderen Art bemerkenswerthe Eigenthümlichkeiten, aber letztere kommen doch nicht so ausschliesslich gerade dieser Art zu, dass sie als durchgreifende Unterscheidungsmerkmale angesehen werden können. Vielmehr finden sich selbst die Eigenschaften, welche zunächst charakteristisch für bestimmte Vertreter der Gruppe „Bacillus mucosus capsulatus“ und für ihre Differenzirung von anderen Angehörigen der gleichen Gruppe werthvoll zu sein schienen, einmal nicht immer in der ursprünglichen, ausgesprochenen Weise bei diesen, dann aber können sie, mehr oder weniger ausgeprägt, auch bei anderen, Anfangs ein wesentlich verschiedenes Verhalten zeigenden Arten, theils nach längerer Fortzüchtung auf künstlichen Medien, theils nach Passage durch den Thierkōrper auftreten. Im Gegensatz dazu bleibt die wesentlichste culturelle Verschiedenheit, die Beschaffenheit der Kartoffelcultur, beständig und unverändert erhalten.

Bei der Besprechung des culturellen Verhaltens sollen die fraglichen Kapselbacillen, unabhängig von den aufgestellten Gruppen, bei den verschiedenen Nährböden in einer Reihenfolge vorgeführt werden, in welcher die auf Grund ihrer Wachsthumseigenthümlichkeit für den betreffenden Nährboden zusammengehörigen Bacillen neben einander und die den allmählichen Uebergang $\mathrm{zu}$ den anderen Arten vermittelnden hinter einander gruppirt sind.

Allen den genaunten Mucosusarten gemeinsam ist die Schnelligkeit des Wachsthums auf den gebräuchlichen Nährsubstraten, die sich besonders energisch in den bei Brüttemperatur gehaltenen Culturen zu erkennen giebt. Hier tritt schon nach wenigen Stunden eine üppige Wucherung auf. Nach einigen Tagen ist der Höhepunkt des Wachsthums erreicht; nach diesem Zeitpunkte scheint eine bemerkenswerthe Vermehrung nicht mehr stattzuhaben. Auch bei Zimmertemperatur geht das Wachsthum gut vor sich. An die Reaction der Nährmedien stellen die Kapselbacillen keine besonderen Ansprüche; sie zeigen auf alkalischen wie auf sauren Substraten ein gleich gutes Gedeiheu. Der unbeschränkte Luftzutritt 
wirkt fördernd auf ihre Entwickelung ein, sie vermehren sich stets dort am üppigsten, wo sie in unmittelbarem Contact mit der Luft stehen. Doch ist die Gegenwart des Sauerstoffes für ihr Fortkommen kein unbedingtes Erforderniss. Auch bei mangelhafter oder fehlender 0 -Zutuhr findet ein, wenngleich langsameres und weniger üppiges, so doch immerhin deutliches Wachsthum statt. Die fraglichen Bacillen sind also sämmtlirh facultative Anairobier.

Bine wejtere, sämmtlichen Arten gemeinsam zukommende Bigemschaft ist die, dass sie auf Gycerinagar und in Milch schon nach 24 stündiger Züchtung bei tiruttemperatur eine ausgesprochen saure heaction hervorrufen. Ier Belag auf schräg erstarrtem alkalischen Glycerinagar, sowie das durch Culturmassen getrübte Condensationswasser reagirten wach 24 stunden stets stark sauer. Die gleiche Reaction ${ }^{1}$ konnte auch in Tage bis Wochen alten Culturen constatirt werden. Ebenso wurde die ursprünglich amphotere Reaction der Milch (s. später), gleichgültig, ob diese durch die Bacillen coagulirt oder ron ihnen unverändert gelassen war, in eine dentlich saure verwandelt. Dagegen zeigte die mit den Kapselbacillen inficirte alkalische Nährbouillon (ebenso alkalisches Peptonwasser) nach 24 Stunden eine ausgesprochen, nach mehreren Tagen eine stark bezw. sehr stark alkalisehe, niemals eine saure Reaction (nur beim Mucosus XIII fand sich nach 48 Stunden zuweilen eine schwach saure, später stets eine deutlich alkalisehe Reaction). Der „Bacillus mucosus capsulatus" erweist sich also, wenigstens für die beiden erstgenannten Culturmedien, als rascher und energiseher säurebildner.

\section{Wachsthum auf Glycerinagar.}

Auf Agarplatten zeigen die rerschiedenen Mucosusarten ein nach Farbe und Consistenz der Colonieen etwas abweichendes, im Cebrigen durchaus identisehes Verhalten. Nach 24 Stunden bei $37^{\circ} \mathrm{C}$. sieht man in der Tiefe punkt- bis stecknadelkopfgrosse, rundliche, ovale oder wetzsteinförmige, hellgelbweissliche, undurehsichtige Colonieen (mikroskopisch hellgelbbräunlich, dicht- und feingekörnt; Rand scharf, glatt oder unregelmässig gezackt bezw. mit Einbuchtungen versehen) und stecknadelkopfbis kleinlinsengrosse, kreisrunde, grauweissliche, scharf-und glattrandige, durchscheinende Colonieen (mikroskopisch im Centrum gelbbräunlich, un-

1 Zuweilen fand sich in Culturen, die mehrere Woehen bei Zimmertemperatur gehalten waren, die Anfangs stark saure Reaction in eine sehwach saure bezw. alkalische verwandelt. Die Kapselbacillen scheinen also die Eahigkeit zu haten auf Girernagar zunäbst Saure, suater sizali zu bilder. 
durchsichtig; in der Peripherie durchsichtig, aus kleinsten, glänzenden, abwechselnd helleren und dunkleren Kügelchen bestehend). Auf der Oberfläche zeigen sich hiersekorn- bis linsengrosse, flachgewölbte, kreisrunde, scharfrandige, grauweisslich-glasige bezw, mattweissliche Colonieen von schleimiger Consistenz und homogener Beschaffenheit; im Centrum derselben findet sich zuweilen eine Delle oder eine Gasblase (mikroskopisch wite die grösseren Colonieen in der Tiefe. Rand zart, nicht ganz scharf, leicht unregelmässig. Farbe gelb - bis schwarzbräunlich. Im Innern, central oder excentrisch gelegen, zuweilen ein von den kleinsteu tiefliegenden Colonieen gebildeter Kern). Auf Agarplatten, wo nur wenig Colonieen vorhanden sind, wachsen diese nach einigen Tagen bei Zimmertemperatur bis zur Grösse eines Pfennigs aus, tlachen sich allmählich ab, confluiren auch häutig.

Die Platten verbreiten bei sämmtlichen Kapselbacillen stets einen angenehm aromatischen Gernoh (nach frischem Brote, nach Hollunderblüthen oder nach Caramel).

Im Ausstrich auf schräg erstarrtem Glycerinagar zeigen die fraglichen Kapselbacillen nach 24 stündiger Züchtung bei $37^{\circ}$ ein ausserordentlich üppiges Wachsthum. ${ }^{1}$ Der sehmale Impfstich hat sich nach diesem Zeitraum in einen dicken, über den grössten Theil der Agaroberfläche ausgebreiteten, flachgewölbten Rasen mit steil abfallenden, scharfen, theils ziemlich glatten, theils unregelmässig gezackten orler mehr gleichmässig gekerbten Rändern verwandelt. Nach einigen Tagen flacht sich der Anfangs prominente Belag mehr und mehr ah und nimmt als gleichmässig erhabene Masse die ganze Oberfläche des Nährbodens ein. Die Consistenz des Belages ist eine ausgesprochen schleimig-zerfliessliche. In Folge dessen rutşchen die Culturmassen allmählich in die Reagensglaskuppe hinab und füllen diese rollständig aus, während auf der Agaroberfläche nur eine dünne, durehscheinende Sehleimschicht zurüekbleibt.

In allen Culturen findet sich in mehr oder weniger deutlicher Weise der erwähnte charakteristische Geruch.

${ }^{1}$ Eine Ausnahme von diesem Verbalten machten der M. 69 und der aus Ozaenanase (nach Behandlung derselben mit antiseptischen Irrigationen) gezüchtete Mueosuธ (III). Der erstere, welcher ursprünglich eine sehr grosse Wachsthumsenergie zezeigt hatte (E. Fraenkel), bildete nach längerer Fortzïchtung auf künstlichen Nährböden nur eine mässig uppige Wucherung, die sich auch bei Cultivirung aus dem Thierkörper nioht wesentlich und hochstens vorubergehend reichlicher gestaltete. Dor letatere wuchs ran vornherein spärlich; die Passage durch den Thierkorper tabte aemer:ai fördernden Eintluss auf sein Gedoihen aus. 
Wachsthum auf schräg erstarrtem Glycerinagar (24 Stunden bei $37^{\circ} \mathrm{C}$.

M. I-IV, Gleichmässiger, ausgesprochen feucht-schleimigVII; zertiesslicher, grau weisslich-glasiger (mit einem B. pneum. Stich in's Gelbliche), nicht fadenziehender Belag Friedländer mit unregelmässig gezackten, bezw. gebuchteten

I. u. III. Rändern. Die Culturmasse zeigt längere Zeit wenig Neigung, nach abwärts zu rutsehen; erst nach Wochen hat sich der grösste Theil des Belages in der Reagensglaskuppe angesammelt, anf der Agaroberfläche nur eine dünne, stark durchscheinende Schleimschicht zurücklassend. Das intensiv getrübte Condenswasser ist dünnflüssig, behält diese Beschaffenheit auch nach Wochen noch bei oder wird allmählich schwerfliesslich, dickschleimig (nicht oder nur angedeutet fadenziehend). NB. Der M. I bildete nach Passage durch den Thierkörper (Maus, Taube) einen deutlich fadenziebenden Belag; das Condenswasser war nach 24 bis 48 Stunden so zähschleimig, dass es sich nicht ausgiessen liess. Doch ging dieses Verhalten nach wenigen Uebertragungen wieder vollständig verloren. - Bei weiterer Cultivirung auf Agar ist das Wachsthum zeitweise ein weniger üppiges; die Farbe des Belages wird mattweisslich oder porzellanweiss (im auffallenden, noch mehr im durchfallenden Lichte hellgelblich oder hellgelbbräunlich). Auch erscheint die Oberfläche weniger feucht, mebr wachsartig glänzend, leicht uneben, und die Consistenz ist eine dünnschmierige. Später (nach Tagen oder erst nach Wochen) stellt sich auch in diesen Culturen ein ausgesprochen feuchtzerfliessliches, mehr oder weniger zähschleimiges Wachsthum ein. Am Rande tritt häufig (nach 24 Std.) ein schmaler, flacher, irisirender, feingekerbter Sanm auf. Zeitweise (auch bei Züchtung aus dem 'Thierkörper) erhebt sich die Peripherie der sonst in toto gleichmässig flachgewölbten Vegetation ein wenig über das, eine seichte Rinne bildende Centrum. Der Belag zeigt entweder ein homogenes Aussehen oder lässt eine feine, durch intensivere Färbung ausgezeichnete Fiederung bezw. fächerartige Strichelung erkennen.

M. X, XI. Wie vorher; doch Belag stets ausserordentlich üppig, stärker gewölbt, etwas zähschleimiger (nicht fadenziehend), durchweg ausgesprochen feucht-zerfliesslich. Oberfläche glatt oder leicht uneben. Das mehrere Tage lang oder dauernd dünnflüssig bleibende Condensationswasser wird zeitweise allmählich ausgesprochen zähschleimig, lässt sich alsdann durch Schütteln kaum fortbewegen.

B. capsul. Pfeiffer.
Wie vorher; doch exquisit zähschleimigfadenziebend.
Meist lebhaft, zeitweise gering; nur zuweilen beim $\mathrm{M}$. VII und beim Bac. pneum. Friedl. ganz fehlend.

Meist ausserordentlich stürmisch (Agar und Belag von zahlreichen Gasbläschen durchsetzt, letzterer durch grössere Gasblasen emporgehoben); nach längeren Uebertragungen nur noch mehr oder weniger lebhaft (auch nach Züchtung aus dem Thierkörper!.

Lebhaft, gering oder fehlend. 


\begin{tabular}{l|l|}
\hline M. VI, IX, & $\begin{array}{l}\text { Wachsthum auf schräg erstarrtem Glycerinagar } \\
\left.\text { (24 Stunden bei } \mathbf{3} 7^{\circ} \mathrm{C} .\right)\end{array}$ \\
XII. & $\begin{array}{l}\text { Anfangs genau wie M. X und XI sich verhaltend, } \\
\text { später, theils spontan (M. IX), theils nach Passage } \\
\text { durch den Thierkörper (M. VI und XII bei Züch- } \\
\text { tung aus Taubenkörper, nicht bei Züchtang aus } \\
\text { Mäuse- oder Meerschweinchenkörper) andauernd } \\
\text { ausgesprochen fadenziehende Beschaffenheit (wie } \\
\text { Bacillus capsulatus Pfeiffer) zeigend. }\end{array}$
\end{tabular}

M. VIII, Gleichmässiger, stets ausgesprochen feucht-schleiXIV.

mig-zerfliesslicher, etwas fadenziehender Belag von glasigem Aussehen. Rand scharf, ziemlich glatt oder unregelmässig gezackt. Das durch abwärts gerutschte Culturmassen getrübte Condenswasser bleibt längere Zeit dünnschleimig, wird erst allmählich schwerfliesslich; nur zuweilen ist es schon nach 24 Std. so zähschleimig, dass es sich nur bei stärkerem Schütteln fortbewegen lässt. Zeitweise zeigt es auch nach Wochen eine dünnflüssige $\mathbf{B e}$ schaffenheit. - Nach längerer Fortzüchtung von Agar zu Agar nimmt der Belag eine mehr grauweisslich- oder mattweisslich-glasige, im durchfallenden Lichte hellgelbliche Färbung an, zeigt keine deutlich fadenziehende Consistenz $u$. wächst etwas weniger üppig. Der Rand lässt eine ziemlich regelmässige Zackung erkennen; bei einzelnen Culturen findet sich in der Peripherie ein zarter, schmaler, irisirender Sanm, welcher mit feinen Zacken oder Querleisten versehen ist. NB. Belag bei M. VIII nur in den ersten Generationen fadenziehend, später nicht mehr.

M. V,

M. aus

Uzaena-

secret

I u. II.
Homogener, stets ausgesprochen feucht-schleimigzerfliesslicher Belag von glasigem Aussehen und von ausserordentlich zähschleimiger, fadenziehender Beschaffenheit. Ränder scharf, glatt oder leicht gebuchtet, bezw. unregelmässig gezackt. Die Culturmasse rutscht allmählich, der Schwere folgend, nach abwärts und sammelt sich in der Reagensglaskuppe an, diese vollständig ausfüllend. Das intensiv und gleichmässig getrübte Condenswasser ist bereits nach 24 Std. derart zähschleimiggallertig, dass es sich durch Schütteln der umgestülpten Eprouvette nicht fortbewegen lässt. Nach längeren Uebertragungen tritt an der Grenze des leicht gewölbten Belages ein etwas flacherer, schmaler, mattweisslicher, feingebuchteter Saum auf. Die Culturmasse erscheint im auffallenden Lichte grauweisslich-glasig, im durchfallenden hellgelblich u. lässt feine, weissgraue, sich fächerartig von unten nach oben ausbreitende Strichelungen erkennen. Zeitweise ist die Farbe d. Belages auch im auffall. Lichte eine grauweissl.-hellgelbi. Der Randsaum ist alsdann entweder in toto gelbl. gefärbt oder es findet sich nur ein gelb gefärbter Strich an der Grenze zwischen ihm u. dem eigentlichen Belage. Die Anfangs stets ausserordentlich zähschleimige Consistenz verwandelt sich nach einiger Zeit zuweilen in eine mehr dünnschleimige. ,
Gasbildung

Meist lebhaft, selten gering oder fehlend.

Bei M. VIII gering od. ganz fehlend. Bei M. XIV Anfangs auch bei zahlr. Uebertragungen stets vermisst, dann in geringem Maasse und vorübergehend nach Passage durch den Thierkörperauftretend, später zuweilen ganz spontan sich einstellend. Zumeist fehlend oder geringfügig.

Bald nur gering, bald deutlicher, zeitweise sehr lebhaft; selten ganz fehlend. 
Wachsthum auf schräg erstarrtem Glycerinagar (24 Stunden bei $37^{\circ} \mathrm{C}$.)
Gasbildung
M. XIII, Genau wie M. aus Ozaenasecret, doch Belag nach B. pneum. vielfachen Uebertragungen stets ausgesprochen. Friedl. II. : glasig (im durchfallenden Lichte grauweisslich oder erst hellgelblich) und homogen (g Linienzeichnung; anftretend), zeitweise n Randsaum). Rand meist glatt, nur wenig gezackt. | sehr lebhaft (zufällig Las mit abgesehwemmten Cultnrmassen erfüllte | oder nach Züchtung Condenswasser ist ausserordentlich zähschleimig, aus dem Thierkörper); unbeweglich; wird erst nach Wochen etwas bei Bac. pnenm. Friedl. flüssiger.

M. 69. Genau wie M. aus Ozaenasecret, doch weniger iippig. Belag der Uberfläche mehr adhärent; in (auch nach Passage lrolge dessen Condenswasser nur wenig getrübt, durch $d$. Thierkörper), ziemlich leicht fliesslich. Consistenz des Belages sonst gering, ganz ausstets exquisit fadenziehend.

M. aus Als schmales, flaches, homogenes Band von gran-

Gzaena weisslich-glasigem Ausseher u. von zähschleimig. secret III. fadenziehender Beschaffenheit. Rand scharf, unregeimässig gezackt. Condenswasser nur wenig getrübt, dünnflüssig.
Bei M.XIII fehlend oder gering (häufig meist lebhaft, zuweilen gering, selten ganz fehlend. hafter.

Nicht vorhanden.

In den mehrere Wochen alten Culturen wurde zeitweise eine leichte Bräunung des Belages, sowie des Agars beohachtet. Dieselbe trat am Constantesten und Deutlichsten bei den zur Gruppe I gehörigen Mucosusarten auf (hier ausnabmsweise auch schon nach einigen Tagen). Weniger häufig und weniger ansgesprochen fand sie sich hei den übrigen Arten; nur beim X. XIII und beim Bac. pneum. Friedländer II wurde sie gänzlich rermisst. Sehr häufig stellte sich bei den rersehiedenen Kapselbacillen nach einigen Tagen oder erst später eine weissliche Trübung des Nährbodens ein.

In Agarstichculturen (Agar mit Zusatz von Glycerin, ameisens. Natron, Trauben-, Milch oder Rohrzucker) bilden die Bacillen nach 24 Stunden auf der Oberfläche eine gut linsengrosse, rundliche, flachgewölbte, scharfund glattrandige Colonie. die sich schnell über die ganze Oberfläche als flache Schleimschicht ausbreitet. Deutlicher, gleichmässig his unten reiokender Impfstich, dessen Ränder seitliche Ausbuchtungen zeigen.

Auf schräg erstarrtem Hammelblutserum zeigen die Bacillen ein im Ganzen etwas weniger uppiges, sonst mit dem auf Glycermagar identisches Wachsthum. 


\section{Wachsthum auf Nährgelatine (10 Proc.).}

Auf Gelatineplatten ist das Wachsthum ein langsameres, im Uebrigen dem auf Agarplatten durchaus ähnliches. Die oberflächlichen Colonieen crreichen nur eine mässige Grösse, erheben sich etwas mehr äler das Niveau des Nährbodens. Nur bei dem Bace pneumon. Friedländor II (aus Nasensecret) zeigten sice eine so starke Prominenz, dass sie in ansgesprochenster. Weise die Form eines porzellanenen Tapeziernagelkopfes wiedergaben.

Das Wachsthum anf sehräg erstarter Gelatine ähnelt dem im Agarstich; doch ist der Belag weniger üppig, nicht so ausgesprochen schleimigzerfliessend und haftet fester an der Oberfläche des Nährbodens. Nach einigen Tagen bildet sich zuweilen um die ca. $1^{\mathrm{cm}}$ breite Wachsthums: zune herum ein zarter, grauer, irisirender Saum, dessen Rand entweder unregelmässig gezackt oder mit kolbigen F'ortsätzen versehen ist.

In Stichenlturen auf Gelatine entsteht nach 24 Stunden bei $22^{\circ} \mathrm{C}$. im Verlaufe des ganzen Stichcanales eine bandförmige, weissgraue bezw. weissgelbliche Vegetation mit glatten oder unregelmässig gezackten Rändern. Der Impfstich zeigt sich zusammengesetzt aus dichtgedrängten, perisehnurartig aneinander gereihten, punkt- bis stecknadelknopfgrossen Kügelchen, welche in mehreren Reihen nebeneinander stehen und theilweise oder grösstentheils zu einem homogenen Streifen verschmolzen sind. Au Stellen, wo sie weniger dicht gesät sind, können die Colonieen des Stichcanales nach einigen Tagen bis zu Jinsengrösse erreichen.

Auf der Oberfläche der Gelatine bildet sich nach 24 Stunden eine etwa linsengrosse, rundliche, mattweissliche oder grauweisslich-glasige Colonie von feucht-schleimig-zerfliesslicher bezw. zähschleimig-fadenziehender Consistenz und mit scharfem, glattem oder etwas gezacktem Rande. Im Centrum wird zuweilen eine kleine Delle beobachtet.

Ein eigentlicher "Nagelkopf" fand sich nur bei dem aus Nasensecret gezüchteten Bac. pneumon. Friedländer (II), bei allen übrigen Kapselbacillen hatte die oberflächliche Colonie eine flachgewölbte, nagelkopfähnliche Form.

Bei weiterem Wachsthum flacht sich die Anfangs gewölbte Kupps mehr und mehr ah - behält ihre gleichmässige Beschaffenheit bei oder zeigt die Audeutung mehrerer concentriseh geschichteter Ringe - und breitet sich allmählich über den grössten Theil bezw. über die gauże Oberfläche aus. Nach längeren Uebertragungen bietet die oberflächliche Colonie zeitweise ein weniger ausgesprochen schleimiges, sondern mehr trockenes, wachsartig glänzend eder mattgesehliffenem flase ähnliches Eussehen dar: die Oberfache zeigt leichte Unebenheiten, and im ai- 
kreise der Colonie tritt nach mehreren Tagen 'ein schmaler, zarter, grauer, blattartig gezackter oder feingezähnelter Saum auf. Central findet sich manchmal - entweder schon nach 24 Stunden oder erst später - eine kleine, knopfförmige Verdickung.

Nur beim Mucos. XIII und beim Bac. pneumon. Friedländer (II) war das Oberflächenwachsthum ausnahmslos ein exquisit feuchtschleimiges und gleichmässiges.

Bei sämmtlichen Mucosusarten trat nach ca. drei Wochen - mitunter auch schon früher - eine leichte Bräunung der obersten Gelatineschicht auf. Am deutlichsten zeigte sich diese Färbung bei den zur Gruppe I gehörigen Kapselbacillen; bei den übrigen war sie ganz gering oder es fand sich an ihrer Stelle nur eine leichte weissliche Trübung des Nährbodens.

Die Entwickelung von Gasblasen kam in gewöhnlicher Gelatine niemals zur Beobachtung. In älteren Culturen bildeten sich infolge Austrocknung Luftblasen und Spalträume, die, wenn sie in der Nähe der Oberfläche gelegen waren, durch abwärts gerutschte Culturmassen ausgefüllt wurden.

In Gelatine mit Zusatz von Trauben- oder Milchzucker war das Oberflächenwachsthum ein etwas üppigeres; auch kam es hier bei den meisten Arten zu einer mehr oder weniger lebhaften Gasbildung (s. später).

Wachsthum auf Kartoffeln (im Reagensglase).

Die zur Gruppe I gebörigen Arten bildeten auf Kartoffeln nach 24 Stunden bei $37^{\circ} \mathrm{C}$. einen üppigen, prominenten, gleichmässig erhabenen, hellgelbweisslichen oder mehr gelbbräunlichen Belag mit steil abfallenden, gekerbten Rändern. Consistenz einer dünnen Salbe. Oberfläche feuchtglänzend, glatt oder in toto bezw. an einzelnen Stellen trocken, uneben. Nach wenigen Tagen breitet sich die Culturmasse über den grössten Theil der Kartoffelobertläche aus, wird feuchter, rahmartig, zerfliesslich und bildet schliesslich einen graugelblichen bezw. mattweisslichen, dünnschmierigen, zum Theil in die Reagensglaskuppe hinabgeflossenen, flachen Belag.

In anderen Culturen bleibt derselbe längere Zeit prominent. Zumeist treten schon nach 24 Stunden, besonders dann, wenn die Züchtung bei Bruttemperatur geschah, in den oberflächlichen Auflagerungen zahlreiche kleinste Gasblasen auf, die nach zwei bis drei Tagen bis Linsen- und Erbsengrösse erreichen und die ganze Masse gleichmässig durchsetzen. Zeitweise stellt sich die Gasentwickelung erst nach 2 bis $3 \times 24$ Stunden ein und ist überhaupt eine wenig lebhafte; doch wird sie niemals voll- 
ständig vermisst. Das Kartoffelfleisch zeigt gewöhnlich schon nach 24 Stunden, ausnahmsweise erst später, eine graugelbbräunliche bezw. bleigraue Verfärbung.

Geruch der Culturen stets angenehm frisch, aromatisch.

Die zur Gruppe II gehörigen, sowie die in der Mitte zwischen beiden Gruppen stehenden Arten wuchern auf den Kartoffeln in Gestalt von reichlichen, schleimigen, fadenziehenden, in der Farbe von dem des Nährbodens nicht zu unterscheidenden Ueberzügen, ${ }^{1}$ die sich immer mehr auf der Oberfläche der Kartoffel ausdehnen und stets dieselben Merkmale beibehalten. Die Kartoffel zeigt feuchten Glanz, keine Farbenveränderung. Gasbildung kam auf Kartoffeln niemals zur Beobachtung.

Der von den Culturen ausgehende Geruch war stets ein aromatischer (nach Caramel oder nach Bierwürze).

\section{Wachsthum in Bouillon.}

Die mit den verschiedenen Kapselbacillen inficirte Nährbouillon lässt nach 24 stündiger Züchtung bei $37^{\circ} \mathrm{C}$. eine diffuse, mehr oder weniger dichte, grauweissliche Trübung erkennen. Bei den auf Agar als schleimigfadenziehender Belag wachsenden Arten entsteht an der Oberfläche der Flüssigkeit eine Kahmhaut, welche meist ringförmig und ziemlich fest an der Innenfläche des Reagensglases adhärent ist. Am Boden findet sich eine geringe Menge eines grauweisslich-glasigen, schleimigen Niederschlages, der beim Schütteln langsam in Form von Fäden oder als zopfartige Masse aufsteigt und sich erst allmählich in der Bouillon gleichmässig vertheilt. Bei den übrigen Bacillen tritt an der Oberfläche ausser einem ringförmigen, weniger fest haftenden Beschlage gewöhnlich nach einigen Tagen ein zarter, grauweisslicher oder ein dicker, mattweisslicher, leicht zerfallender, nicht zusammenhängender Belag, ganz ausnahmsweise eine resistente Haut auf. Das am Boden des Glases befindliche, mehr oder weniger reichliche, grauweissliche oder hellgelbliche Sediment, welches von schleimig-albuminöser Beschaffenheit ist, erhebt sich beim Schütteln in Gestalt von Fäden und Flocken und vertheilt sich ziemlich schnell in der überstehenden Flüssigkeit.

Die Bouillonculturen verbreiteten entweder gar keinen oder einen angenehm aromatischen Geruch (nach süsser Milch).

' Der M. VIII und XIV, sowie der M. aus Ozaenasecret (II) bildeten zuweilen auf jungen Kartoffeln einen grauweissen, gelegentlich auch in's Gelbliche spielenden Rasen. 
Gasbildung fehlte für gewöhnlich; nur in vereinzelten Culturgläsern traten beim schütteln reichliche kleinste Gasbläschen auf.

Indolreaction negativ.

\section{Wachsthum in steriler Milch.}

(Die Keimfreiheit der in Reagensgläsern befindlichen Milch, welche discontinuirlich an drei aufeinanderfolgenden Tagen (jedesmal 20 Minuten lang) sterilisirt war, wurde durch mehrtägigen Aufenthalt im Brütschrank geprüft. In die auf diese Weise als keimfrej constatirte Nährflüssigkeit wurde eine Platinöse 24 stündiger Agarcultur übertragen. Die Züchtung fand bei Körpertemperatur statt. Das Verbalten der Kapselbacillen in Milch wurde zu wiederholten Malen untersucht, theils bei jeder Art für sich, theils bei sämmtlichen Arten gleichzeitig nebeneinander. Im letzteren Falle wurde stets Milch von ein und derselben Abkochung benutzt. Die an ungeimpften Controlröhrchen geprüfte Reaction war eine amphotere.)

Die mit M. I, II, III, IV, VI inficirte Milch zeigte meistentheils nach 24 Stunden flockige und klumpige Gerinnung, Abschridung eines Anfangs klaren, später trüben Serums und stark saure Reaction. In mehreren Fällen fand sich nach 24 Stunden ausser reichlichen, kleinsten Gasbläschen und deutlich saurer Reaction keine sichtbare Veränderung, und erst nach 2 bis $3 \times 24$ Stunden stellte sich Gerinnung bei ausgesprochen saurer Reaction ein. In anderen Culturgläsern blieb die Milch dauernd unverändert, doch reagirte sie nach 24 Stunden stets sauer.

Der M. V, sowie der Bac. pneumon. Friedländer (I, II, III) und der Bac. capsul. Pfeiffer brachten die Milch meistens nach zwei bis drei Tagen, zuweilen auch schon nach 24 Stunden, zur Gerinnung. Hier und da blieb selbst nach acht Tagen jede sichtbare Veränderung aus. Nach 24 Stunden war die Reaction, anch der unverändert gebliebenen Milch, stets eine deutlich saure.

Der M. 69 und die aus Ozaenasesecret gezüchteten Kapselbacillen ${ }^{1}$ (I, II und III) bewirkten zuweilen nach zwei Tagen eine flockige bezw. klumpige Gerinnung der Milch, zumeist ljessen sie dieselbe jedoch unverändert. Reaction nach 24 Stunden stets deutlich sauer.

Der M. XIII führte niemals eine sichtbare Veränderung der Milch herbei. Die Reaction war nach 24 bezw. 48 Stunden theils amphoter,

1 Während nach Abel (a.a. O.) der „Ozaenabacillus“ die Milch nicht verändert, bringt er sie nach Palta uf (Ref. in Baumgarten's Jahresbericht, 1891, Bd. VII, S. 266) - ebenso wie das Bacterium Friedländer - zur Gerinnung. 


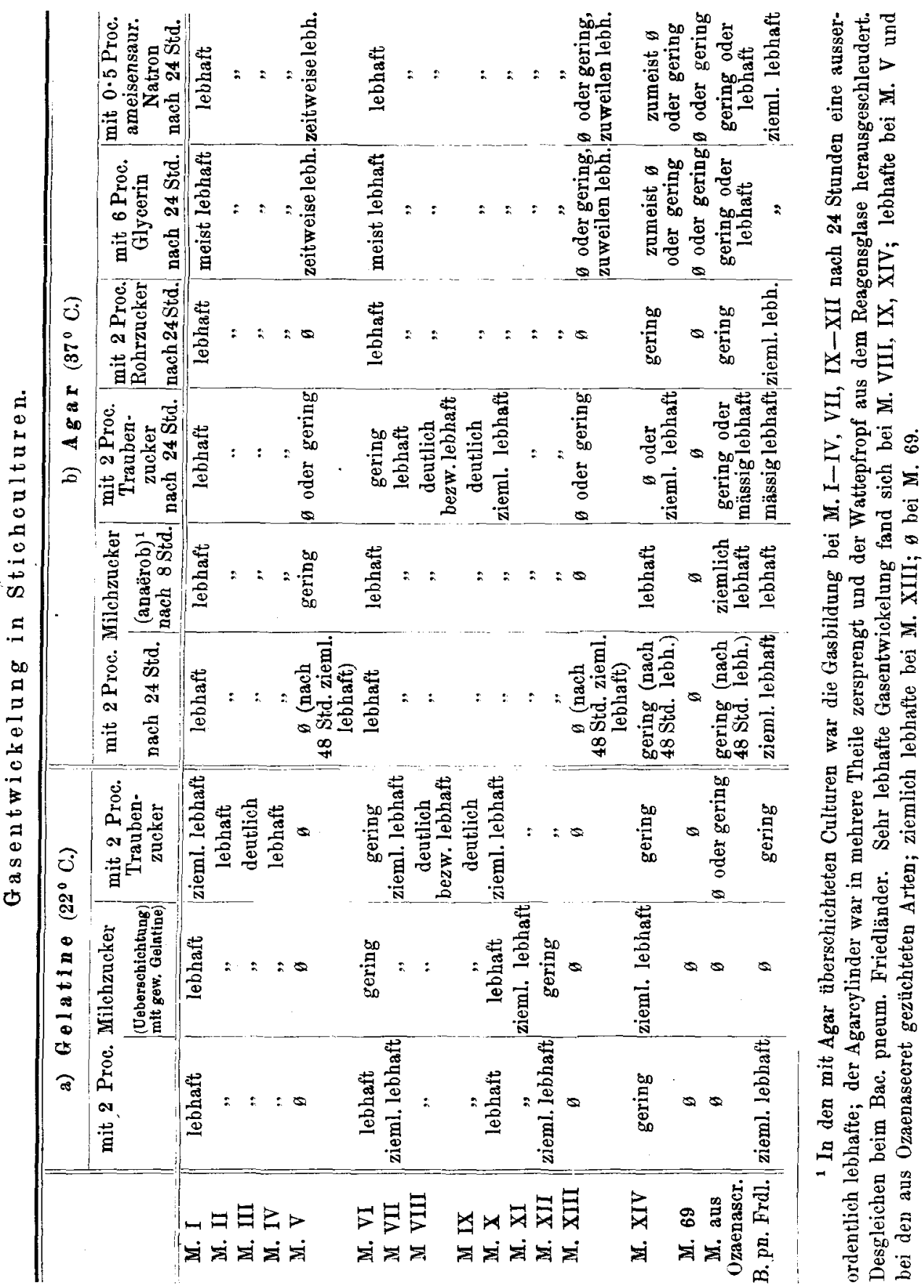


theils deutlich sauer, später schwach sauer. Dies Verhalten wurde bei zahlreichen Culturen beobachtet.

Der M. XIV brachte die Milch gewöhnlich nach 24 bis 48 Stunden zur Gerinnung; zeitweise war dieselbe nach 24 Stunden weniger dünnflüssig, sonst unverändert. Reaction stets ausgesprochen sauer.

Die Mucosusarten VII bis XII coagulirten die Milch zumeist nach 24 Stunden, seltener nach 48 Stunden, ausnahmsweise erst nach $3 \times 24$ Stunden bei stark saurer Reaction. Die mit M. VII inficirte Milch war nach 24 Stunden zuweilen schwerer fliesslich, sonst unverändert.

Die verschiedenen Milchculturen entwickelten keinen oder einen angenehm aromatischen Geruch. In älteren Culturen konnten die eingeimpften Kapselbacillen nur in spärlicher Menge nachgewiesen werden, während nach 24 stündiger Züchtung bei $37^{\circ} \mathrm{C}$. ein gutes Wachsthum zu constatiren war.

\section{Thierversuche.}

A. Weisse Mäuse, subcutan an der Sehwanzwurzel geimpft (das Impfmaterial wird mit der Platinöse in eine auf dem Rücken angelegte Hauttasche eingeführt). ${ }^{1}$

Bac. mucos. capsulat. VIII:

Maus 1, grosse Oese, am 21./III. 1896, nach 8 Tagen durchaus munter; gleiche Menge am 29./III. inoculirt: Thier dauernd gesund.

Maus 2, drei Theilstriche einer Pravaz-Spritze vom Peritonealexsudat eines nach intraperitonealer Impfung todten Meerschweinchens injicirt, 7./IV., dauernd munter.

Maus 3, der grösste Theil einer 24 stündigen Cultur auf schräg erstarrtem Glycerinagar $=$ II. Uebertragung vom Peritonealexsudat eines intraperitoneal geimpften Meerschweinchens, 8./IV., keinerlei Krankheitserscheinungen.

Maus 4, drei Viertel der Milz einer nach intraperitonealer Infection todten weissen Maus in die Hauttasche gebracht, 11./IV., Thier dauernd munter.

1 Die Menge der verimpften Culturmasse ist nach der Grösse der Platinösen berechnet worden (grosse Oese $=6^{\mathrm{mm}}$ lang und $3^{\mathrm{mm}}$ breit; mittelgrosse Oese $=4^{\mathrm{mm}}$ lang und $2^{\mathrm{mm}}$ breit; kleine (ese $=3^{\mathrm{mm}}$ lang und $2^{\mathrm{mm}}$ breit). Dort, wo das Impimaterial nicht besonders bezeichnet ist, wurden stets 24 Stunden alte Glycerinagarculturen benutzt. 
Maus 5, [24 Stunden bei $37^{\circ} \mathrm{C}, 2 \times 24$ Stunden bei Zimmertemperatur gezüchtete], Cultur auf schräg erstarrtem Agar, mit etwas Bouillon verrieben = eine Pravaz'sche Spritze voll, an der Schwanzwurzel injicirt, 15./IV., Tod nach ca. 18 Stunden. Die Section ergiebt ausser Milztumor und hochgradiger Schwellung der Nieren, die gut doppelt so gross als in der Norm sind, nichts Besonderes. Im Herzblut ziemlich reichliche, im Milzsaft sehr zahlreiche, charakteristische Bacillen mit sehr sohöner, breiter Kapsel. Ausstrich auf Agarplatten ergiebt gleichfalls Reinculturen. - Paraffinschnitte der Niere, mit Unna's polychromem Methylenblau gefärbt, lassen sehr reichliche Bacillen (nur hier und da ist eine Kapsel sichtbar) in den Gefässen und den Malpighi'schen Körperchen erkennen; die Capillaren sind zum Theil durch längsliegende Bacillen verstopft. In den Harncanälchen sind keine Mikroorganismen nachweisbar; doch finden sich hier entzündliche Veränderungen (hyaline Cylinder).

Maus 6, die halbe Milz von Maus 5, 16./IV., ohne Erfolg: es treten bei 3 Wochen langer Beobachtungsdauer nicht die geringsten Krankheitserscheinungen auf.

Maus 7, die ganze 24 stündige Culturmasse von schräg erstarrtem Agar =II. Uebertragung vom Peritonealexsudat eines der intraperitonealen Infection erlegenen Meerschweinchens, 27./IV., Thier dauernd gesund.

Maus 8, grosse Oese, 5./VI., dauernd munter.

Bac. mucos. capsulat. I:

Maus 1, grosse Oese, 21./III., bleibt gesund; am 29./III. zum zweiten Male die gleiche Dosis, dauernd munter.

Maus 2, mehrere grosse Oesen, 15./IV. - es stellen sich nicht die geringsten Krankheitserscheinungen ein.

Bac. mucos. capsulat. III:

Maus 1, grosse Oese, 6./IV;

Bac. mucos. capsulat. IV:

Maus 1, grosse Oese, 6./IV. - dauernd gesund.

Bac. muc. capsulat. VII:

Maus 1, grosse Oese, 6./IV., bleibt gesund.

Bac. mucos. capsulat. II:

Maus 1, grosse Oese, 7./IV., Tod nach 4 Tagen (sass längere Zeit vor dem Tode mit gesträubtem Fell und zusammengekniffenen Augenlidern da, reagirte nicht, Athmung beschleunigt). Sectionsbefund: An der Impfstelle unter der Haut klares Exsudat; ausgedehnter fibrinöser Belag; gelatinössulzige Veränderung der Weichtheile. Schwellung der Inguinal- und Axillardrüsen; zwischen ihnen dilatirte Gefässe. Sonst ausser sehr grossem Milztumor nichts Auffallendes. Mikroskopisch im Exsudat an der Impfstelle sehr zahlreiche pleomorphe Bacillen, häufig zu zwei liegend, ohne deutliche Kapsel; desgleichen im Milzsaft und Herzblut - hier mit schöner, breiter Kapsel. Auf Agarplatten (Ausstrich) überall Reincultur von Mucosus (üppiges, feuchtglänzendes, nicht sehr ausgesprochen schleimig-zerfliessliches Wachsthum; mattweissliche Farbe).

Zeitschr. f. Hygiene. XXJII. 
Maus 2, mittelgrosse Oese, 28./IV., Tod nach 3 Tagen. Section: Befund wie vorher. Die Veränderung an der Impfstelle greift weit in die Tiefe (im klaren Exsudat reichlich Leukocyten und sehr zahlreiche Bacillen mit deutlicher Kapsel). Hydrops vesicae felleae. Grosser Milztumor.

Maus 3, kleine Oese, 3./V., andauernd gesund.

Maus 4, mittelgrosse Oese, 5. VI., desgleichen.

Bac. mucos. capsulat. V:

Maus 1, kleine Oese, 27./V., Tod nach 21/2 Tagen. An der Impfstelle sehr ausgedehnter, dicker, derber, fibrinös-eitriger Belag, in der Umgebung sulzig-glasige Beschaffenheit des Gewebes, die sich tief in die Musculatur hinein erstreckt. Reichlich glasiger, schleimig-fadenziehender Beschlag. Sehr starke Schwellung der Inguinal- und Axillardrüsen, zwischen diesen und der Impfstelle stark gefüllte Gefässe. Ganz colossaler Milztumor. Sehr grosse Nieren. Leber geschwollen, auf der Oberfläche kleine grauweissliche Pünktchen sichtbar. Im Darm zähschleimiger, fadenziehender, hellgelblicher Inhalt. Ueberall (mikroskopisch und culturell) die charakteristischen Bacillen in Reincultur (nur im Darminhalt mit anderen Bakterien vergesellschaftet) - sehr reichlich, mit sehr schöner, breiter Kapsel: vorwiegend grosse plumpe Stäbchen, zum Theil leicht gebogen, oft paarig angeordnet, doch auch rundliche und ovale, kleinere und grössere Gebilde.

Bac. mucos. capsulat. XIII:

Maus 1, mittelgrosse Oese, 14./V., Tod nach 3 Tagen. Befund genau wie bei Mucos. V.

Bac. mucos. capsulat. XIV:

Maus 1, mittelgrosse Oese, 30./V.;

Maus 2, grosse Oese, 5./VI.;

Maus 3, grosse Oese, 17./VI. - bei keinem Thiere irgend welche Krankheitserscheinungen.

Bac. mucos. capsulat. VI:

Maus 1, mittelgrosse Oese, 26./VI. - dauernd gesund.

Bac. mucos. capsulat. IX:

Maus 1, kleine Oese, 14./VI., Tod nach ca. 38 Stunden. Sectionsbefund: Hochgradige Veränderungen an der Impfstelle (tief in die Musculatur hineingreifend), feuchtschleimig-fadenziehender, glasiger Beschlag auf dem fibrinös-nekrotischen Gewebe. Starke Röthung und Schwellung der Lymphdrüsen in Leistenbeuge und Achselhöhle; stark gefüllte Gefässe. Peritoneum glatt, spiegelnd; kein Peritonealexsudat. Organe der Bauchhöhle gross, blutreich. Milz enorm geschwollen (Länge $2 \cdot 3^{\mathrm{cm}}$; Breite $6^{\mathrm{mm}}$ ). Im Darm gelblicher, zähschleimiger Inhalt. Lungen gebläht, blutreich, ohne Herdaffection. Pleurahöhlen ohne abnormen Inhalt. Mikroskopisch im Exsudat an der Impfstelle enorm reichliche Stäbchen, nur selten mit schöner, breiter Kapsel umkleidet, und mässig zahlreiche, zum Theil Bacillen ent- 
haltende Leukocyten. Im Milzsafte und Herzblute reichlich Bacillen mit sehr schöner, breiter Hülle. Auf Agarplatten Reincultur (ausgesprochen feucht-schleimig-zerfliessliches, etwas fadenziehendes, grauweisslich-glasiges Wachsthum).

Bac. mucos. capsulat. $X$ :

Maus 1, mittelgrosse Oese, 18./VI.;

Maus 2, mittelgrosse Oese (von II. Uebertragung auf schräg erstarrtem Agar aus Herzblut eines intraperitoneal geimpften Meerschweinchens), 28./VI. - dauernd gesund.

Bac. mucos. capsulat. XI:

Maus 1, mittelgrosse Oese, 24./VI., Tod nach 3 Tagen. (In den letzten 24 Stunden schwerkrank, sitzt regungslos mit gesträubtem Felle da. Athmung beschleunigt. Augenlider verklebt, im Bindehautsack reichliches, wässeriges Secret [mikroskopisch keine Bacillen nachweisbar]. Dünne, zähschleimige Fäces, in denen mikroskopisch ausser mannigfachen Formen zahlreiche charakteristische Bacillen, zum Theil mit sehr schöner Kapsel, nachweisbar sind. Kothausstrich auf Agarplatte: üppiger, grauweisslicher, ausgesprochen feucht-schleimig-zerfliessender, grösstentheils confluirter Belag. Mikroskopiseh fast nur Bac. mucos., theilweise mit deutlicher Kapsel versehen).

Section: Ausserordentlich starkes, fast über den ganzen Rücken ausgedehntes Infiltrat; lebhafte Röthung der Haut. Die ganze Gegend ist in cine sulzig-gallertige, feucht-glasige Masse verwandelt; der Process erstreckt sich tief in die Musculatur hinein. Mikroskopisch ausser mässig reichlichen, zum Theil mit Bacillen angefüllten Leukocyten enorm zahlreiche pleomorphe Gebilde, theilweise mit schöner, breiter Kapsel. Milz $2^{\mathrm{em}}$ lang, $8^{\mathrm{mm}}$ breit. Im Milzsafte sehr reichliche charakteristische Bacillen, grösstentheils gekapselt. Herzhöhlen mit dunkelrothem, flüssigem Blute strotzend gefüllt (mikroskopisch sehr zahlreiche pleomorphe Bacillen mit schöner Kapsel). Därme mit gelblichem, zähschleimig-fadenziehendem Inhalt gefüllt (ziemlich reichliche Luftblasen enthaltend); mikroskopisch enorm reichliche charakteristische Gebilde mit deutlicher Kapsel. Auf Agarplatten (Ausstrich) überall Reincultur.

Bac. mucos. capsulat. XII:

Maus 1, mittelgrosse Oese, 24./VI.;

Maus 2, grosse Oese von frisch aus Meerschweinchenkörper gewonnener $\Lambda$ garcultur, 28./VI. - dauernd gesund.

Der Mucosus 69 ist für weisse Mäuse hochgradig pathogen; nach zahlreichen, von E. Fraenkel (und Verfasser) angestellten Versuchen gingen die Thiere nach subcutaner Inoculation kleiner Dosen 24stündiger 
Agarcultur ansnahmslos, meist im Laufe von zwei bis vier Tagen, zu Grunde. In vereinzelten Fällen trat der Tod später, in einem Falle erst nach 17 Tagen ein (E. Fraenkel). Die Section ergab stets die beschriebenen Veränderungen an der Impfstelle, welche jedoch unter äusserlich gleichen Infectionsbedingungen bei den einzelnen Versuchsthieren in Bezug auf Intensität wie Extensität beträchtlich variirten. Die Milz war ausnahmslos enorm stark vergrössert. Im Uebrigen glich der Befund vollständig dem beim Mucos. V. Auch hier fanden sich stets, in mehr oder weniger reichlicher Zahl, die oben erwähnten, rundlichen, punkt- bis stecknadelkopfgrossen, grauweisslichen Herde auf der Leberoberfäche. An der Impfstelle, im Herzblute und im Safte der Milz liessen sich die Bacillen sowohl in gefärbten Deckglaspräparaten, als auch dureh das Culturverfahren stets in Reincultur nachweisen. Am reichlichsten wurden sie in den Ausstrichpräparaten des Exsudates an der Impfstelle (hier nur zum Theil mit einer deutlichen Kapsel rersehen) und der Milz (hier, ebenso wie im Herzblute, von einer schönen, breiten Hülle umgeben) angetroffen.

In genau der gleichen Weise, wie auf den Mucos. 69, reagirten weisse Mäuse auf die subcutane Impfung mit den aus Ozaenasecret gezüchteten schleimbildenden Kapselbacillen. In mehreren Versuchen, in welchen kein auffallender Unterschied bezüglich der Infectiosität zwischen älteren und jungen, zwischen üppig wuchernden und spärlicher wachsenden Culturen constatirt werden konnte, gingen die geimpiten Thiere nach Linverleibung kleiner Culturmengen ohne Ausnahme innerhalb zwei bis fünf Tagen an Septicämie zu Grunde. Die Section ergab die gleichen Veränderungen, wie sie bei der Infection mit dem Mucos. 69 gefunden wurden; besonders bemerkenswerth war auch hier die progrediente Gewebsnekrose an der Impfstelle und die hochgradige Vergrösserung der Milz. Dagegen wurden die Herde auf der Leberoberfläche nicht in allen Fällen constatirt.

Anm. Die subcutane Impfung mit einer mittelgrossen Dosis 24 stündiger Agarcultur des Bac. pneum. Friedländer und des Bac. capsulatus Pfeiffer, welche bei je einer weissen Maus ausgeführt wurde, blieb ohne jede schädliche Einwirkung auf diese Thiere.

Weisse Mäuse, intraperitoneal geimpft (eine mittelgrosse Oese von 24 stünd. Agarcultur, mit $1 / 2{ }^{\mathrm{cm}}$ Bouillon verrieben).

Mucosus VIII:

Maus $1,1 / 2{ }^{\mathrm{cm}}$ Peritonealexsudat eines intraperitoneal geimpften Meerschweinchens, 10./IV., Tod nach ca. 15 Stunden. Enormer Milztumor. Im Milzsafte und Herzblute mikroskopisch und eulturell sehr reichliche charakteristische Bacillen mit sehr deutlicher Kapsel in Reincultur nachweisbar. Kein Exsudat in Brust- und Bauchhöhle. 
Maus 2, 31./V., Tod nach 6 Stunden; sitzt bald nach der Impfung regungslos mit halbgeschlossenen Augen da; beschleunigte Athmung, reichliche Thränensecretion. -- Peritoneum feuchtglänzend, lebhaft injicirt. Spur grauröthlichen, fadenziehenden Exsudates. Milz enorm vergrössert, Nieren stark geschwollen. Leber gross, blutreich. Im Darme gelblich-glasiger, zähschleimiger Inhalt. Keine stärkeren Drüsenschwellungen. Pleurahöhlen leer; Lungen gebläht, ohne Herderkrankung. Mikroskopisch im Peritonealexsudate enorm reichliche, sehr pleomorphe Gebilde (vorwiegend rundlich und oval, häufig zu zweien liegend; hier und da längere Stäbchen. Kapsel nur selten anzutreffen) und ziemlich spärliche Leukocyten; im Darminhalte sehr reichliche Bacillen mit schöner Kapsel, ausserdem dichtgedrängte Formelemente; im Milzsafte und Herzblute ebenfalls sehr zahlreiche, deutlich gekapselte Bakterien. Ueberall, mikroskopisch und culturell, Reinculturen.

\section{Mucosus XIV:}

Maus 1, 31./V., Tod nach $6^{1 / 2}$ Stunden. Befund wie vorher bei Maus 2. Milz nicht ganz so enorm vergrössert.

\section{Mucosus XIII:}

Maus 1, 31./V., Tod nach 7 Stunden. Kein Peritonealexsudat. Im Uebrigen genau wie bei Maus 2, Mucos. VIII.

Mucosus V:

Maus 1, 31./V., Tod nach $9^{1 / 2}$ Stunden. Etwas fadenziehender Beschlag auf den Darmschlingen; Milz stark vergrössert. Im Darme hellgelblichglasiger, zähschleimiger Inhalt. Röthung und Schwellung der Axillar- und Inguinaldrüsen, zwischen welchen sich erweiterte und stark gefüllte Gefässe ausbreiten. Sonst Befund wie vorher.

\section{Mucosus 69:}

Maus 1, 31./V., Tod nach 8 Stunden. Ergebniss der Section, des mikroskopischen und culturellen Befundes genau wie bei Mucosus V.

\section{Mucosus I:}

Maus 1, 1./VII., Tod nach 10 Stunden. Peritoneum glatt, spiegelnd, etwas injicirt, feuchtglänzend durch geringen, zähschleimigen Beschlag. Milz dunkelblauroth; $2^{\mathrm{mm}}$ lang, $7^{\mathrm{mm}}$ breit. Leber und Nieren geschwollen, blutreich. Auf der Leberoberfläche vereinzelte rundliche, grauweissliche, bis stecknadelkopfgrosse Knötchen sichtbar. Gallenblase durch wasserhelle Flüssigkeit stark dilatirt (mikroskopiseh und culturell darin Reincultur der charakteristischen Kapselbacillen). Lungen gebläht, blutreich. Herzhöhlen strotzend gefüllt mit dunkelrothem, flüssigem Blute. Bauch- und Brusthöhle frei von Exsudat. Im Darme gelblicher, zähschleimiger Inhalt.

Mucosus II;

Maus 1, 1./VII., Tod nach 14 Stunden. Milz $1.9^{\mathrm{cm}}$ lang, $8^{\mathrm{mm}}$ breit. Hydrops vesicae felleae (dünne wasserhelle Flüssigkeit). 
Mucosus VI:

Maus 1, 1./VII., Tod nach 16 Stunden. Milz $1 \cdot 4^{\mathrm{cm}}$ lang, $4^{\mathrm{mm}}$ breit. Organe nur mässig geschwollen, nicht sehr blutreich.

Mucosus XII:

Maus 1, 1./VII., Tod nach 10 Stunden. Milz $1 \cdot 5^{\mathrm{cm}}$ lang, $6^{\mathrm{mm}}$ breit. Hydrops der Gallenblase. Schwellung und Blutreichthum der inneren Organe etwas weniger hochgradig, sonst Befund genau wie bei Mucosus I, ebenso bei Mucosus II und VI.

Mucosus VII:

Maus 1, 6./VII., Tod nach 10 Stunden. Milz sehr blutreich; $1.8^{\mathrm{cm}}$ lang, $5^{\mathrm{mm}}$ breit. Hyperämie und Schwellung der inneren Organe. Lungen gebläht, blutreich. Starke Schwellung und Röthung der inguinalen und axillaren Lymphdrüsen, zwischen denen sich ein Netz von erweiterten Gefässen ausbreitet. Gallenblase ohne Besonderheit. Im Milzsafte und Herzblute die injicirten Bacillen mikroskopisch und culturell in Reincultur nachweisbar.

Mucosus X:

Maus 1, 6./VII., Tod nach 10 Stunden. Milz $2 \cdot 2^{\mathrm{cm}}$ lang, $6^{\mathrm{mm}}$ breit. Im Uebrigen genau wie vorher. - In jeder Uterushälfte fanden sich drei wohlausgebildete Föten mit Placenten vor. Mit Unna's polychromem Methylenblau gefärbte Paraffinschnitte, welche aus einem Fötus und der zugehörigen Placenta hergestellt wurden, liessen im mütterlichen Theile der Placenta sehr zahlreiche Bacillen erkennen. Dagegen wurden dieselben im fötalen Theile und im Fötus selbst völlig vermisst.

B. Meerschweinchen, intraperitoneal geimpft (eine grosse Oese 24stündiger Agarcultur, mit $1^{\mathrm{ccm}}$ Bouillon verrieben).

Mucosus VIII:

Meerschweinchen 1, 6./IV., Tod nach ca. 18 Stunden. - Bauchfell etwas geröthet. In den abhängigen Theilen der Peritonealhöhle mässig reichliches, trüb gelbbräunliches, stark fadenziehendes Exsudat (mikroskopisch fast nur Bacillen, theils frei, theils in einer feinfädigen bezw. feinkörnigen Grundsubstanz liegend; grosse pleomorphe, meistentheils mit deutlicher Kapsel versehene Gebilde. Ausserdem spärliche Leukocyten). Etwas schleimigeitriger Belag auf der Leber- und Milzoberfläche. Innere Organe geschwollen, blutreich. In den Pleurahöhlen spärliches, klares, stark fadenziehendes Exsudat (mikroskopisch sehr zahlreiche, zum Theil mit Bacillen angefüllte und Protoplasmaveränderungen zeigende Leukocyten. Bacillen hier bedeutend spärlicher wie im Peritonealexsudat).

Meerschweinchen 2, 9./IV., Tod nach ca. 18 Stunden. Befund genau wie vorher. Milz auch hier nicht auffallend stark vergrössert.

Meerschweinchen 3, eine grosse Oese 24 stündiger Agarcultur mit $1^{\mathrm{ccm}}$ Bouillon verrieben, davon 2 Theilstriche einer Pravaz'schen Spritze am 11./IV. injicirt. Thier darnach durchaus munter. Am 13./IV. $1 / 2$ Oese, in $1^{\mathrm{cm}}$ Bouillon aufgeschwemmt, intraperitoneal injicirt. Am 14.jIV. schwerkrank, 
sitzt mit gesträubtem Felle und zusammengekniffenen Augenlidern da, reagirt nicht. Am 15./IV. desgleichen. Temperatur $33.7^{\circ} \mathrm{C}$. Am 16./IV. ist es etwas munterer. Temperatur $34 \cdot 5^{0} \mathrm{C}$. 17./IV. leidlich munter, geringe Steifigkeit des gekrümmten Rückens. Fell gesträubt. Augen geschlossen. Temperatur $34 \cdot 3^{0} \mathrm{C}$. 18./IV. desgl. Temperatur $34 \cdot 5^{0}$ C. 19./IV. Morgens Tod (= Tod nach 8 Tagen).

Sectionsbefund: Ausser Milztumor und zahlreichen hämorrhagischen Erosionen der Magenschleimhaut keinerlei Veränderungen. Im Herzblute und Milzsafte konnten weder im mikroskopischen Präparate noch durch das Culturverfahren Bacillen naohgewiesen werden; ebensowenig gelang der Nachweis von Bakterien in Nierenschnitten. Die hämorrhagische Erosionen enthaltenden Stücke der Magenwandung wurden in Paraffin eingebettet; die Schnitte mit Unna's polychromem Methylenblau gefärbt. Mikroskopisch fand sich an diesen Stellen ein umschriebener Epithelverlust und diesem entsprechend in der Submucosa herdförmige Anhäufung von Hämatoidinkrystallen. Bacillen waren nirgends vorhanden.

\section{Mucosus I:}

Meerschweinchen 1, 6./IV., Tod nach ca. 16 Stunden. - Bauchfell geröthet. Reichliches, trüb gelbbräunliches, stark fadenziehendes Peritonealexsudat (mikroskopisch sehr spärliche Leukocyten, vorwiegend Bacillen mit deutlicher Kapsel). Reichlicher, schleimig-eitriger Belag auf der Leberoberfäche, sowie auf der Pleura der rechten Lunge. In der rechten Pleurahöhle reichliches, links spärliches, stark fadenziehendes Exsudat (mikroskopisch zahlreiche Leukocyten, mässig reichliche Kapselbacillen).

\section{Mucosus II:}

Meerschweinchen 1, 7./IV., Tod nach 6 Stunden. - Peritoneum lebhaft injicirt, spiegelnd. In der Bauchhöhle reichliches, dünnflüssiges, trübes, stark blutig tingirtes Exsudat (mikroskopisch enorm reichliche Bacillen, Kapsel nur hier und da deutlich; spärliche zum Theil mit Bakterien gefüllte Leukocyten). Milz ziemlich stark vergrössert, blutreich. Pleurahöhlen frei. Lungen stark gebläht, sonst ohne Besonderheit. Rechter Ventrikel mit geronnenem Blute gefüllt.

\section{Mucosus XIII:}

Meerschweinchen 1, 1./VI., keinerlei Krankheitserscheinungen; am 7./VI. die gleiche Dosis zum zweiten Male injicirt; Tod nach 8 Stunden. - Lebhafte Injection des Peritoneums und der Darmserosa. In der Bauchhöhle eine grosse Menge ziemlich klaren, hellgelbbräunlichen, etwas fadenziehenden Exsudates. Milz nicht deutlich vergrössert. In beiden Pleurahöhlen eine Spur Flüssigkeit von der gleichen Beschaffenheit wie in der Peritonealhöhle. Herz gross, rechter Ventrikel mit theilweise geronnenem Blute gefüllt. Lungen gebläht, blut- und saftreich, ohne Herdaffection; Oberfläche spiegelnd, mit dünnem, fadenziehendem Belag bedeckt. Leber, Nieren blutreich, ohne sonstige Veränderungen. Mikroskopisch und culturell Reincultur von charakteristischen Kapselbacillen im Blute und in den Organsäften. Auf Nierenschnitten finden sich in den Capillaren, welche zum Theil stark erweitert 
und mit Blut angefüllt sind, sehr zahlreiche Bacillen, hier und da sind sie in spärlicher Menge auch in den Harncanälchen anzutreffen. Keine Parenchymveränderung.

Meerschweinchen 2, 5./VII., schon 3 Stunden nach der Injection nicht mehr so munter wie vorher. 6./VII., deutliches Kranksein. Temperatur $39 \cdot 2^{\circ}$. 7./VII., desgl. Temperatur $38 \cdot 8^{\circ}$. .8./VII., wieder ziemlich munter. 9./VII., gesund.

\section{Mucosus V:}

Meerschweinchen 1, 1./VI., nur vorübergehend krank; am 7./VI. zum zweiten Male mit der gleichen Dosis inficirt; Tod nach 11 Stunden. Befund wie vorher, nur etwas hochgradiger. Peritoneum parietale getrübt; auf der Leberoberfläche fibrinös-eitriger Belag. Reichliches, etwas fadenziehendes Exsudat. Milz deutlich vergrössert, blutreich. Pleurahöhlen leer. Auf den Lungen etwas stark fadenziehender Beschlag. Im Dünndarm reichliche, trübgelbliche, nicht fadenziehende Flüssigkeit. Leber und Nieren blutreich, sonst ohne Besonderheit.

\section{Mucosus XIV:}

Meerschweinchen 1, 1./VI., Tod nach ca. 16 Stunden. - Reichliches, trüb gelbbräunliches Peritonealexsudat von schleimiger, nicht fadenziehender Beschaffenheit; lebhafte Injection des Peritoneums; fibrinös-eitriger Belag auf Darm- und Leberoberfläche. Organe ohne Besonderheit.

Meerschweinchen 2, 7./VI., nur vorübergehend krank.

\section{Mucosus XII:}

Meerschweinchen 1, 24./VI., Tod nach ca. 18 Stunden. - Lebhafte Injection des Peritoneums; das parietale Blatt mattglänzend. Mässig reichliche Menge trübhellgelbbräunlichen, fadenziehenden Exsudates; fibrinöseitriger Beschlag auf Leber- und Milzoberfläche. Leber, Milz, Nieren blutreich. Pleurahöhlen leer; Lungen gebläht, blut- und saftreich. Herzhöhlen mit theilweise geronnenem Blute angefüllt.

Meerschweinchen 2, 26./VI., Tod nach ca. 6 Stunden. Milz vergrössert, sehr blutreich. Ziemlich reichliches, nicht fadenziehendes Exsudat in der Bauchhöhle. Dünndarmschleimhaut lebhaft geröthet; zähschleimiger, hellgelblicher Darminhalt. Magenschleimhaut etwas injicirt. Herzhöhlen mit flüssigem Blute prall gefüllt. Im Uebrigen wie vorher.

Mucosus X:

Meerschweinchen 1, 26./VI., Tod nach ca. 8 Stunden. Sectionsbefund genau wie bei Muc. XII, Meerschweinchen 2.

Mucosus IX:

Meerschweinchen 1, 24./VI., dauernd gesund.

Mucosus XI:

Meerschweinchen 1, 26./VI., desgleichen. 
Mucosus 69:

Meerschweinchen 1, 1./VI,;

Meerschweinchen 2, 26./VI., zeigen dauernd nicht die geringsten Krankheitserscheinungen.

Mucosus aus Ozaenasecret:

Meerschweinchen 1, 1./VI,

Meerschweinchen 2, 26./VI., bleiben dauernd völlig gesund.

Mucosus VI:

Meerschweinchen 1, 5./VII., schon 3 Stunden nach der Impfung weniger munter, sitzt ruhig in einer Ecke des Käfigs da, ächzt beim Anrühren, Tod nach 12 Stunden, nachdem es schon stundenlang vorher Seitenlage eingenommen hatte. In der Bauchhöhle mässig reichliches, stark blutig tingirtes, flüssiges Exsudat von etwas fadenziehender Beschaffenheit. Peritoneum parietale und Darmserosa lebhaft injicirt, feuchtglänzend. Geringer fibrinöseitriger Beschlag auf der Oberfläche von Leber, Milz und Därmen. Leberoberfläche dicht besät mit kleinsten, rundlichen, grauweisslichen, punkt- bis stecknadelkopfgrossen Knötchen. Milz, Leber und Nieren gross und blutreich. Dünndarmschleimhaut intensiv geröthet; im Dünndarm hellgelblicher, dünnschleimiger Inhalt. Pleurahöhlen ohne Exsudat; rechter Ventrikel und beide Vorhöfe mit dunkelrothem, flüssigem Blute gefüllt. Linker Ventrikel stark contrahirt, leer. Lungen gebläht, blutreich. - Schwellung und Röthung der inguinalen Lymphdrüsen. Aus Blut und Organsäften wurden mikroskopisch und culturell die charakteristischen Bacillen in Reincultur erhalten.

Mucosus VII:

Meerschweinchen 1, 6./VII., bleibt vollständig munter.

Mucosus III:

Meerschweinchen 1, 8./VII., Tod nach 6 Stunden. In der Peritonealhöhle ziemlich reichliches, trübhellgelbbräunliches, nicht fadenziehendes Exsudat. Etwas fibrinös-eitriger Beschlag auf Leber- und Milzoberfläche. Peritoneum lebhaft injicirt. Innere Organe geschwollen, blutreich. Lungen stark gebläht. Sonst nichts Besonderes. Im Dünndarm, dessen Schleimhaut intensiv geröthet, hellgelblicher, zähschleimiger Inhalt.

Mucosus IV:

Meerschweinchen 1, 8./VII., Tod nach 6 Stunden. In der Bauchhöhle mässig reichliches, trübes, glasiges, stark fadenziehendes Exsudat. Dünndarminhalt von gleicher Beschaffenheit. Im Uebrigen Befund wie vorher.

C. Tauben, intramusculär geimpft (eine grosse Oese 24 stündiger Agarcultur, in $1 / 2{ }^{\mathrm{ecm}}$ Bouillon aufgeschwemmt, in den Brustmuskel injicirt):

Die am 31./V. mit Mucosus I, V, VIII, XIII, XIV, 69, am 6./VI. mit Mucosus XII und Mucosus aus Ozaenasecret auf diese Weise geimpften Thiere bleiben vollständig gesund. 
Tauben, intraperitoneal inficirt (eine grosse Oese 24stündiger Agarcultur, mit $1^{\mathrm{cm}}$ Bouillon verrührt):

Die mit Mucosus V, VIII, XIII, 69 am 12./VI., mit Mucos. 69 und Mucos. aus Ozaenasecret am 26./VI., mit Mucosus II, III, XII am 7./VII. geimpften Thiere bleiben dauernd munter. Bei den mit Mucosus IX am 24./VI., mit Mucosus VI und XI am 27./VI., mit Mucosus X am 26./VI. und 6./VII. inoculirten Tauben treten nur vorübergehende Krankheitserscheinungen (Mattigkeit, verminderte Fresslust, Speichelfluss) auf.

Mucosus XIV:

Taube 1, 13./VI., Tod nach ca. 17 Stunden. - Ausgedehnte, hochgradige, fibrinös-eitrige Peritonitis. Keine Flüssigkeitsansammlung. Die Organe der Brust- und Bauchhöhle ohne Besonderheit. Im Herzblute spärliche, im Milzsafte sehr reichliche, ausserordentlich pleomorphe Bacillen mit schöner, breiter Kapsel. Ausstriche von Herzblut und Milzsaft ergeben Reinculturen.

Taube 2, 7./VII., nur vorübergehend krank.

Mucosus XII:

Taube 1, 24./VI., nur vorübergehend leicht krank.

Taube 2, 26./VI., Tod nach 36 Stunden. Hochgradige, fibrinös-eitrige Peritonitis mit ausgedehnten Verklebungen der Darmschlingen. Peritoneum lebhaft injicirt. Leber, Milz, Nieren mässig gross und blutreich. Sonst nichts Besonderes. Mikroskopisch finden sich im Herzblute und Milzsafte zahlreiche, mit deutlicher Kapsel versehene, pleomorphe Bacillen; im Peritonealbelag (hier nur zum Theil gekapselt) sind sie in enormer Menge anzutreffen. Der schleimig-glasig-fadenziehende Darminhalt (Darmschleimhaut lebhaft geröthet) besteht aus sehr zahlreichen Epithelien und vielgestaltigen Mikroorganismen, die grösstentheils eine deutliche Hülle zeigen. Auf den mit Blut und Organsäften bestrichenen Glycerinagarplatten wächst der $\mathrm{Mu}$ cosus überall in Reincultur.

\section{Mucosus I:}

Taube 1, 5./VII., Tod nach ca. 12 Stunden. In der Bauchhöhle ziemlich reichliches, trübhellgelbliches, zähschleimiges, fadenziehendes Exsudat. Sonst wie vorher. Schleimhaut des Dünndarmes in ganzer Ausdehnung hämorrhagisch, im Dickdarme diffuse, mässig starke Röthung. Darminhalt von dünnschleimiger Beschaffenheit und hellgelblicher Farbe. Mesenterialdrüsen stark geröthet und geschwollen. Ueberall im Blute und in den Organsäften Mucosus in Reincultur!

Taube 2, 7./VII., bleibt gesund.

Mucosus VII:

Taube 1, 6./VII., Tod nach 9 Stunden. Sectionsbefund wie bei Mucosus I, Taube 1. Am Schnabel und in der Mundhöhle zähsehleimiges, glasiges Secret. Im Dünndarme, dessen Schleimhaut intensiv geröthet ist, findet sich reichlicher, theils hellgelblicher, dünnschleimiger, theils glasiger', fadenziehender, zähschleimiger Inhalt. 


\section{Mucosus IV:}

Taube 1, 7./VII., Tod nach 18 Stunden. Befund wie vorher. Auf der Leberoberfläche kleinste, grauweissliche, dichtstehende Pünktchen, die sich mit der Messerklinge nicht abstreifen lassen. Kein Peritonealexsudat. Darmschleimhaut, besonders die des Dünndarmes, intensiv geröthet. Im Dünndarme glasiger, schleimig-fadenziehender Inhalt, im übrigen Darmcanal hellgelbliche, zähschleimige Massen. In gefärbten Deckglaspräparaten des glasigen Dünndarminhalts sehr zahlreiche, zum Theil dicht gedrängt in Haufen liegende Fpithelien und mässig reichliche, charakteristische, gekapselte Bacillen. Hier, wie im Herzblute und Milzsafte, mikroskopisch und culturell Reincultur von Mucosus.

D. Kaninchen, intravenös geimpft (der grösste Theil der Culturmasse von schräg erstarrtem Agar, mit etwas Bouillon verrührt, in die Ohrvene injicirt $=11 / 2$ Pravaz'sche Spritzen).

\section{Mucosus XIII:}

Kaninchen 1, 6./VI. Am 7./VI. Thier etwas matt, frisst nicht. Kein deutliches Kranksein. Temperatur $38.8^{\circ}$. Am 8./VI. sitzt es ganz ruhig da, rührt das Futter nicht an. Tod nach ca. 60 Stunden. - Section: Peritoneum feucht, spiegelnd. Kein Exsudat. Organe der Bauchhöhle ohne Besonderheit. Pleurahöhlen leer. Lungenoberfläche feuchtglänzend. Lungen gebläht; zahlreiche kleinste, subpleurale Hämorrhagieen. Im linken Unterlappen eine haselnussgrosse, hämorrhagisch infiltrirte Partie. Vermehrter Blut- und Saftgehalt. - Rechter Ventrikel mit theilweise geronnenem, dunkelrothem Blute gefüllt. Im oberen Theile des Dünndarmes zahlreiche kleine Blutungen in der Schleimhaut; zähschleimiger, gelbbräunlicher Inhalt. An der der Injectionsstelle entsprechenden Kopfseite Lymphdrüsen geschwollen, Venen etwas stärker gefüllt.

Mikroskopisch im Milzsafte ziemlich reichliche, sehr grosse, häufig zu zweien liegende, mit einem schmalen, lichtbrechenden Hofe und einer breiten Kapsel versehene Bacillen; seltener finden sich rundliche und ovale Formen. Desgleichen im Herzblute, hier nur mässig reichlich vorhanden. Ausstrich auf Glycerinagarplatten ergiebt eine üppig wachsende Reincultur der injicirten Bacillen.

Mikroskopisch im Pleurabeschlag ausser zahlreichen rothen Blutkörperchen mässig reichliche Kapselbakterien (vorwiegend ovale und rundiche Gebilde; deutliche Kapsel).

Mucosus II:

Kaninchen 1, 9./VI., Tod nach 6 Stunden. Befund wie vorher.

Mucosus V:

Kaninchen 1, 9./VI., Tod nach 6 Stunden. Befund wie vorher. 
E. Fütterungsversuche mit Hunden.

Mucosus XI:

Junger (ca. 6Monate alter), kräftiger, gesunder Hund erhält am 30./VI. den Belag von einer 24stündigen Cultur auf schräg erstarrtem Agar, in $100 \mathrm{em}$ süsser Milch verrührt. Die ganze Menge wird schnell verzehrt. Am Abend macht das Thier einen weniger munteren Eindruck, zeigt grosse Unruhe, zittert heftig, nimmt keine Nahrung zu sich. Es erfolgen sehr häufige, schleimig-wässerige Stuhlentleerungen. - Mehrere Kothösen werden in Bouillonröhrchen aufgeschwemmt; aus letzteren wird auf Glycerinagarplatten ausgestrichen, auf welchen der Mucosus ausserordentlich üppig und fast in Reincultur wächst.

Am 1./VII. Status idem. Die Diarrhöe dauert fort. In den Fäces Mucosus mikroskopisch und culturell in Reincultur nachweisbar.

Am 2./VII. Stuhl dünnbreiig. Thier ziemlich munter.

Am 3./VII. Stuhl geformt. Völliges Wohlbefinden.

Desgleichen am 4., 5., 6./VII.

Am 6./VII. wird die Hälfte der vorher verabreichten Culturmenge, mit etwas süsser Milch vermischt, verzehrt. 3 Stunden danach erfolgt ein reichlicher, geformter Stuhlgang, und $1 / \mathrm{g}$ Stunde später werden dünnbreiige Fäces entleert; in letzteren konnten durch das Culturverfahren reichliche Kapselbacillen nachgewiesen werden. Befinden ungestört.

Am 7./VII. Darreichung der gleichen Dosis wie am 6./VII. Stuhlgang geformt.

Am 8./VII. wird die gleiche Menge wie am 30./VI, verzehrt. Es tritt keine Wirkung ein.

N.B. Der Hund war während des ganzen Versuches eingesperrt und erhielt als Nahrung nur Milch.

\section{Mucosus XIII:}

Fin zweiter Hund verzehrt am 2./VII. die mit etwas süsser Milch vermischte Culturmasse von einem Agarröhrchen. 'Bei sonstigem Wohlbefinden erfolgen mehrere Stunden nach der Mahlzeit einige dünne Stuhlentleerungen, aus denen der Mucosus nahezu in Reincultur gezüchtet wird. - Am 3./VII. Stuhl geformt. In dem mit sterilem Glasstabe aus dem Rectum entnommenen Kothe sind keine Kapselbacillen nachweisbar.

Derselbe Hund verzehrt am 12./VII., ebenso am 13./VII., die gleiche Dosis von Mucosus XI, ohne dass irgend welcher Einfluss auf den Allgemeinzustand zu constatiren ist.

\section{Mucosus aus Ozaenasecret:}

Der erstgenannte Hund verzehrt am 11./VIII. den Belag von einer Agarcultur. Es tritt keine Störung der Stuhlentleerung bezw. des Allgemeinbefindens ein; ebensowenig nach Verfütterung der gleichen Dosis am 12./VIII. und der doppelten am 13./VIII. Stuhl geformt bezw. dickbreiig; in demselben sind weder in gefärbten Deckglaspräparaten noch im Ausstrich auf Agarplatten Kapselbacillen nachweisbar. 
Ein anderer, ca. $1 \mathrm{Jahr}$ alter, bisher noch nicht gebrauchter Hund verzehrt am 19./VIII. den Belag von einer Agarcultur. Da sich nach 24 Stunden keine Wirkung eingestellt hat, wird am 20./VIII. die Fütterung mit der gleichen Culturmenge wiederholt. Nach mehreren Stunden treten profuse Diarrhöen auf, die jedoch nur kurze Zeit andauern. Der Hund zeigt vorübergehend Mattigkeit und verminderte Fresslust. Die reichlichen, dünnflüssigen, mit dicken Schleimklumpen vermischten, sehr übelriechenden Fäces enthalten zahlreiche Kapselbacillen; wie sowohl im mikroskopischen Präparate als auch im Ausstrich auf Agarplatten zu constatiren ist.

Ein kleiner, 4 Wochen alter, gut entwickelter Hund verzehrt am 21./VIII. die Hälfte des Belages von einer Agarcultur. Schon nach wenigen Stunden grosse Hinfälligkeit, zeitweise Krämpfe, die Nahrungsaufnahme wird verweigert. Erst nach ca. 20 Stunden erfolgen reichliche, dünnflüssige, mit Schleimklumpen vermischte, übelriechende Entleerungen. Allgemeinzustand kaum gestört; Fresslust noch gering. Die eingeführten Kapselbacillen werden im Ausstrich auf Agarplatten in reichlicher Menge erhalten.

Am 22./VIII. Hund durchaus munter; verzehrt die gleiche Dosis wie vorher. Es stellt sich keine bemerkbare Wirkung ein. Desgleichen am 23./VIII. nach Verfütterung der doppelten Dosis. Im normalen Stuhlgange sind keine Kapselbacillen nachweisbar.

Nach dem Ergebniss der bakteriologischen und anatomischen Untersuchung kennzeichnet sich die Infectionskrankheit, welcher die geimpften Mäuse erlagen, als eine typische Septicämie im bakteriologischen Sinne. In den Fällen, wo in die Bauchhöhle geimpft war, fand sich eine Complication mit Peritonitis. - Ueberall, sowohl in den, dem Orte der Infection entsprechenden Krankheitsherden, als auch im Blute und in den Organsäften, wurden die inoculirten Bacillen mikroskopisch wie culturell stets in Reinculturen nachgewiesen. Das hier und da constatirte, meist spärliche, wässerige Conjunctivalsecret erwies sich als bakterienfrei. In dem, in der Mehrzahl der Fälle vorhandenen, zähschleimigen Darminhalt, sowie in den diarrhöischen Fäces von ähnlicher Beschaffenheit, welche einmal mehrere Stunden vor dem Tode beobachtet wurden, konnten die Bacillen theils rein, theils im Verein mit anderen Arten, im letzteren Falle stets in überwiegender Mehrzahl, angetroffen werden. In dem wiederholt erhobenen Befunde von Hydrops der Gallenblase ergab die mikroskopische und culturelle Untersuchung der wasserhellen Flüssigkeit ausnahmslos das alleinige und reichliche Vorhandensein der charakteristischen Kapselbacillen.

Der anatomische Befund war in allen Fällen, sowohl bei den nach subcutaner, wie bei den nach intraperitonealer Impfung zu Grunde gegangenen Mäusen, im Grossen und Ganzen ein gleichartiger. Abgesehen von den durch den Impfmodus bedingten Versehiedenheiten und den, allem Anschein nach, ohne bestimmte Regel auftretenden Einzelheiten, 
zeigten sich die Organe stets in einer, wenn auch verschieden hochgradigen, so doch im Wesentlichen durchaus identischen Weise verändert.

Aus den Organen der inficirten Thiere wurden vermittelst der Paraffineinbettungsmethode Schnitte angefertigt und diese theils mit Unna's polychromem Methylenblau, theils mit Eosin-Hämatoxylin oder nach der van Gieson'schen Methode gefärbt. Die histologische Untersuchung liess in den verschiedensten Organen, welche sich sehr häufig durch starke Hyperämie auszeichneten, keine Gewebsveränderungen, indess constant Bacillen erkennen, deren Menge in den einzelnen Fällen oft sehr verschieden war. Am zahlreichsten wurden sie in der Milz gefunden, wo sie, zumeist in dichtgedrängten Haufen liegend, zwischen den Zellen, in Lymphräumen und in Gefässen, angetroffen wurden. Auch in den Schnitten der Lunge, der Herzmusculatur, der Leber und Niere sah man sie überall den Blutbahnen folgen und in diesen sich gleichmässig vertheilen. In der Leber wurden sie meistentheils auch in den Gallengängen vorgefunden. Dagegen zeigten sie sich niemals im Inneren von Zellen. Die Capillaren, in denen die Bacillen lagen, das Lumen derselben oft vollkommen ausfüllend, waren vielfach dilatirt. In den Nieren sab man die Bacillen am häufigsten in den zum Theil stark erweiterten und gefüllten Capillaren zwischen den Harneanälchen, nicht nur in der Rinde, sondern auch im Mark, seltener und spärlicher in den Glomerulusgefässen und ganz ausnahmsweise im Lumen der Harncanälchen selbst. Dagegen wurden sie bei den der intraperitonealen Infection erlegenen Mäusen häufiger und zahlreicher an den letztgenannten Localitäten angetroffen. Hier konnten sie sowohl in den Gefässschlingen, als auch zwischen diesen und unter dem Epithel der Malpighi'schen Körperchen constatirt werden. Die mit Bacillen erfüllten Harncanälchen waren theilweise dilatirt.

In den Fällen, wo in der Leber grauweisse Herde beobachtet wurden, ergab die miskroskopische Untersuchung dicht unter der Kapsel mehr oder weniger zablreiche, grössere und kleinere, meist runaliche Inseln von zu Grunde gegangenem Lebergewebe. An diesen Stellen, die sich inmitten vollständig unveränderten Parenchyms befanden, war die Structur des Lehergewebes geschwunden und durch ein spongiöses Gerüst von hyaliner Beschaffenheit ersetzt, durch welches sich hier und da noch einzelne Stränge von erhaltenem Parenchym und ganz blass tingirte protoplasmalose Epithelkerne und Kernschollen hinzogen. Dieser Process schien sich hauptsächlich an der Oberfläche abzuspielen, wenigstens fand er sich an anderen Orten nicht. In den nekrotischen Partieen waren keine Bacillen nachweisbar, nur an der Grenze zwischen todtem und lebendigem Gewebe waren sie augenscheinlich etwas reichlicher als an anderen Stellen vertreten. Irgendwelche entzündlichen Erscheinungen in 
den Herden selbst oder in deren Umgebung wurden in keinem Falle beobachtet.

Das Infiltrat an der Impfstelle bei den subcutan inficirten Mäusen bestand mikroskopisch aus einer dichten Anhäufung von Rundzellen und aus enorm reichlichen Bacillen, die in eine feinfädige, nach der Weigert'. schen Fibrinfärbungsmethode sich tingirende Grundsubstanz eingelagert waren. Auch zwischen den Muskelbündeln liess sich an einzelnen Stellen ein feines Fibrinnetz nachweisen. Mikroorganismen und Zellen konnten bis tief in die Musculatur hinein rerfolgt werden. Sie lagen hier überall, den Lymphbahnen folgend, zwischen den Muskelfasern, welche theils nur verdrängt waren, theils beginnenden Zerfall, Quellung und undeutliche Querstreifung, zeigten. Unter den zelligen Elementen fielen die zahlreich vorhandenen Mastzellen durch ihre Grösse und durch die Eigenart ihrer Färbung mit Unna's polychromem Methylenblau auf. In den grösseren Gefässen, die erweitert und strotzend mit Blut gefüllt waren, wurden keine Bacillen gesehen.

In den mit Unna's Methylenblau tingirten Schnitten erschienen die Bacillen durchweg kleiner, als in den direct aus Blut und Organsäften hergestellten, gefärbten Ausstrichpräparaten; auch war hier, im Gegensatz zu letzteren, nur ausnahmsweise die Gegenwart einer Kapsel zu constatiren. Wo eine solche vorhanden war, zeigte sie eine schwach blauröthliche Färbung und hob sich gut von den intensiv dunkelblau gefärbten Bakterienleibern ab.

Auch bei den nach intraperitonealer Infection zu Grunde gegangenen Meerschweinchen und Tauben war der bakteriologische und anatomische Befund in allen Fällen der einer allgemeinen Sepsis. Während bei den intraperitoneal geimpften Mäusen die entzündliche Erscheinung seitens des Peritoneums nur mässig hochgradig, die Menge des Exsudates sehr gering war - zumeist fand sich nur eine Spur farblosen, fadenziehenden Beschlages auf den Darmschlingen - und Flüssigkeitsansammlung in der Pleurahöhle stets vermisst wurde, führten die Injectionen bei Meerschweinchen ausnahmslos zu einer hochgradigen Entzündung des Peritoneums mit reichlichem, schleimigem Erguss, der sich in geringer Menge auch in der Brusthöhle vorfand, hier meistentheils in Form eines schleimartigen, lediglich aus Kapselbacillen bestehenden Belages auf der Lungenoberfläche auftretend. Bei Tauben war die Peritonitis gleichfalls eine sehr ausgedehnte; sie zeigte hier einen fibrinös-eitrigen Charakter und ging mit oder ohne Ansammlung von Exsudat einher. Die Pleurahöhlen wurden stets leer befunden. Die eingeführten Bacillen fanden sich bei den inlicirten Meerschweinchen und Tauben in den verschiedenen Organen, welche ausser mässiger Schwellung und Hyperämie keinerlei Veränderungen 
zeigten, stets in Reincultur, wịe sowohl in den aus Blut und Organsäften hergestellten Deckglaspräparaten und Agarausstrichen, als auch in den, nach verschiedenen Methoden gefärbten Organschnitten nachgewiesen wurde. Auch hier sah man die Bacillen ausschliesslich in den Lymphund Blutbahnen. Doch waren sie bei beiden Thierclassen lange nicht so massenhaft vorhanden, wie bei den geimpften Mäusen, und wiederholt konnte ihre Anwesenheit im Herzblute nur durch das Culturverfahren constatirt werden. Demnach scheint der Meerschweinchen- und Taubenkörper keinen sonderlich günstigen Boden für eine Vermehrung der Kapselbacillen abzugeben. - In den Fällen, wo grauweissliche Herde in der Leber gefunden wurden, ergab die histologische Untersuchung die gleichen Veränderungen, wie sie sich bei Mäusen zeigten.

Bezüglich des morphologischen Verhaltens der Kapselbacillen im Thierkörper ist zu erwähnen, dass sie in den Gewebssäften der Mäuse am grössten, in den der übrigen Thiere am kleinsten erscheinen.

Der bei allen Versuchsthieren im Darme angetroffene Schleimstoff enthielt ausser reichlichen Formelementen, grossen Epithelien und Leukocyten, stets massenhafte Kapselbacillen, welche häufig in Reinculturen vorhanden waren. Im oberen Abschnitte des Dünndarmes hatten diese Schleimmassen eine zähe, fadenziehende Beschaffenheit und ein glasiges Aussehen, während sie im übrigen Darmcanal mehr dünnflüssig und hellgelblich waren. Die Darmschleimhant zeigte meistentheils eine diffuse Röthung, die am intensivsten und häufigsten im oberen Dünndarm anzutreffen war; hier hatte die Entzündung zuweilen einen hämorrhagisehen Charakter angenommen. In Schnittpräparaten fand sich eine starke Füllung und Erweiterung der Gefässe, sowie hier und da, vorwiegend in der Umgebung der Drüsen, kleine Blutherde; bacilläre Embolieen oder auch nur Anhäufungen von Bacillen in den hämorrhagisch afficirten Theilen wurden niemals gesehen.

Zwecks Darstellung der im Peritoneal- und Pleuraexsudate vorhandenen zelligen Elemente wurden aus diesen Flüssigkeiten nach Art der Bluttrockenpräparate Deckglasausstriche hergestellt, mit concentrirtem Eosincarbolglycerin gefärbt und mit verdünnter wässeriger Methylenblaulösung nachgefärbt. Bei den geimpften Thieren bestanden die im Peritonealexsudat überhaupt sehr spärlich, im Pleuraexsudat ziemlich reichlich vertretenen Leukocyten zum grössten Theile aus ein-, mehr- und vielgestaltkernigen, mit feinen oder gröberen Granulis erfüllten eosinophilen Zellen, welche sonst bekanntlich nur spärlich im Organismus der Thiere anzutreffen sind, und aus den sogen. Mastzellen, welche im Gegensatz zu den ersteren in der Lymphe einiger Säugethiere sehr oft vorkommen. Im Inneren dieser Gebilde wurden niemals Bacillen constatirt, dagegen fanden 
sie sich häufig in der unmittelbaren Umgebung der isolirt liegenden Zellen, den Rändern dicht angelagert; wiederholt wurden sie auch den hier und da vorhandenen rothen Blutkörperchen an und aufliegend vorgefunden. Der Rest der Leukocyten bestand aus grossen und kleinen ein- und mehrkernigen Elementen, die grösstentheils mit Bacillen vollgestopft waren. - Die bei allen Versuchsthieren beobachteten Leukocyten, welche am spärlichsten bei Mäusen vertreten waren, konnten den Kapselbacillen gegenüber ihrer Aufgabe, als Schutzkräfte des Organismus zu dienen, nicht gerecht werden. Die Bacillen vermehrten sich an den Impfstellen schnell und ungestört wie in einem Culturglase, so dass es zu einer erfolgreichen Leukocytose nicht kommen konnte, und führten schliesslich, in die Säftemasse des Körpers gelangend, eine Verallgemeinerung der Infection, eine typische Septicämie herbei.

Nach dem Resultate der Thierexperimente lassen sich die in Frage stehenden Bacillen in zwei Gruppen eintheilen, welche die auf Grund ihres Verhaltens den verschiedenen Thierclassen gegenüber zusammengehörigen Arten umfassen. Die Trennung der Arten wird vor Allem ermöglicht durch die differente, in ihrer Constanz bemerkenswerthe Wirkung, welche sich bei der subcutanen Impfung von weissen Mäusen kundgiebt. Doch auch in ihrem Verhalten den übrigen Versuchsthieren gegenüber lassen die beiden Gruppen in die Augen fallende Verschiedenheiten erkennen.

Gruppe I vereinigt die Mucosusarten, welche weisse Mäuse nach subcutaner Inoculation kleiner Dosen ausnahmslos tödten (M. V, IX, XI, XIII, M. 69, M. aus Ozaenasecret). Dieselben haben auf Meerschweinchen und Tauben bei intraperitonealer Infection gar keine oder nur vorübergehende pathogene Wirkung. Meerschweinchen, welche die einmalige intraperitoneale Impfung mit M. V und XIII überstanden hatten, gingen nach der zweiten Injection der gleichen Dosis in beiden Fällen zu Grunde. Darnach wird also das für diese Arten an sich nicht oder nur wenig empfängliche Meerschweinchen durch eine einmalige Einverleibung von Bakterienmaterial nicht immunisirt, sondern es wird dadurch anscheinend für diese Thiere eine erhöhte Disposition für eine wiederholte Infection mit dem gleichen Virus geschaffen.

Gruppe II umfasst diejenigen Arten, welche bei subcutaner Impfung keinerlei krankmachende Wirkung auf weisse Mäuse ausüben (M. I-IV, VI-VIII, X, XII, XIV). Bei Meerschweinchen führten sie nach intraperitonealer Infection in den meisten Fällen den Tod herbei; nur ausnahmsweise blieben die geimpften Thiere gesund oder erkrankten nur vorübergehend. Diese für Mäuse bei subcutaner Impfung nicht wirksame Gruppe ist also für Meerschweinchen stark pathogen. Eine gleiche Pathogenität zeigte sich bei Mäusen nach intraperitonealer Injection; bei 
diesem Impfmodus gingen die Thiere ausnahmslos zu Grunde. Ein etwas anderes Verhalten war bei den intraperitoneal inficirten Tauben zu constatiren. Diese blieben in etwas mehr als der Hälfte der Fälle gesund oder erkrankten vorübergehend. Der Rest ging an den Folgen der Injection zu Grunde.

Der zeitweise für weisse Mäuse bei subcutaner Inoculation nicht zu kleiner Mengen pathogene Mucosus II wirkt auf Meerschweinchen und Tauben in gleicher Weise wie die zur zweiten Gruppe gehörigen Arten, ist also aller Wahrscheinlichkeit nach diesen zuzurechnen.

Die einmal bei einer mit euormen Culturmengen des Mucosus VIII subcutan geimpften Maus constatirte tödtliche Wirkung ist naturgemäss nicht als eigentliche Infection, sondern als Giftwirkung in Folge der plötzlichen Uebersehwemmung der Körpersäfte mit Bakterienmaterial zu betrachten.

Intravenöse Injectionen bei Kaninchen wurden nur mit einem Bacillus der Gruppe I und mit zweien der Gruppe II ausgeführt. Von ausgedehnten Experimenten nach dieser Richtung hin wurde Abstand genommen, nachdem das Resultat der übrigen Thierversuche die Differenzirung der Arten ermöglicht hatte. Das bei den spärlichen Impfungen mit gewaltigen Culturmengen erzielte Ergebniss macht keinen Anspruch auf Verwerthbarkeit. Der Tod der drei intrarenös geimpften Kaninchen ist keinenfalls auf Rechnung einer Infectiosität der verwendeten Culturen für diese Thiere zu setzen; denn durch die mikroskopische und culturelle Untersuchung konnte eine Vermehrung der Bacillen im Kaninchenkörper nicht nachgewiesen werden, und auch der Sectionsbefund gab für eine solche Annahme keinerlei Anhaltspunkte. Vielmehr handelte es sich auch in diesen Fällen um eine acute Intoxication des mit Bakterien überschwemmten Organismus.

Die Veränderungen an der Impfstelle, welche in Bezug auf Intensität wie Extensität beträchtlichen Schwankungen auch bei den mit gleichwerthigem Bakterienmaterial geimpften Mäusen unterliegen können - im Gegensatz zu den stets viel gleichartiger veränderten Organen --, sind keineswegs charakteristisch für die in Frage stehenden Bakterienarten. Progrediente Gewebsnekrosen können auch durch andere Mikroorganismen verursacht werden, welche mit dem „Bac. mucos. capsulat." nicht identisch sind. So züchtete E. Fraenkel ${ }^{1}$ einmal aus der Highmorshöhle einen auf der Platte von dem Pneumoniecoccus kaum zư unterscheidenden Kapseldiplococcus, welcher bei Mäusen nach subcutaner Einverleibung zu einer von der Impfstelle aus fortschreitenden nekrobiotischen Erweichung

Vgl. Virehnw's Archiv. 1896. Bd. CXIIIII. S. 4 ?. 
Über den sogenannten BaciLLus mucosus capsulatus.

\begin{tabular}{|c|c|c|c|c|c|c|c|c|}
\hline $\begin{array}{l}\Xi \\
\\
\end{array}$ & 密 & ++ & 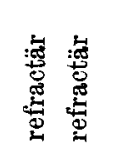 & 1 & 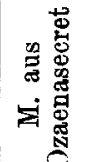 & 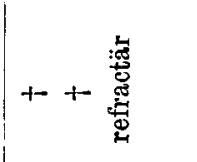 & 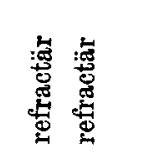 & \\
\hline $\begin{array}{l}\dot{B} \\
\dot{B}\end{array}$ & : & ト漹 & $1+$ & 1 & $\begin{array}{l}8 \\
\dot{z}\end{array}$ & 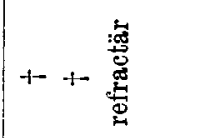 & 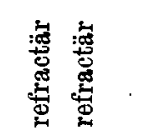 & \\
\hline $\begin{array}{l}\overrightarrow{7} \\
\overrightarrow{7}\end{array}$ & : & $+1-$ & 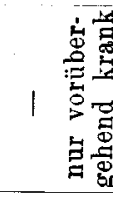 & 1 & $\begin{array}{l}\vec{y} \\
\dot{z}\end{array}$ & 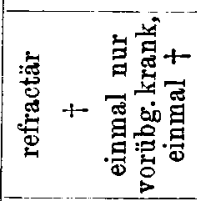 & 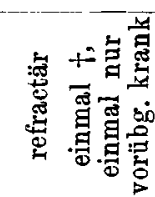 & \\
\hline$\dot{\bar{x}}$ & I- & 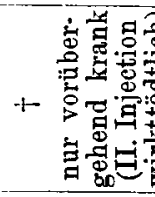 & 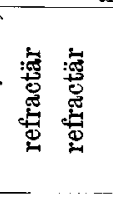 & $\begin{array}{l}A \\
\stackrel{\Phi}{B}\end{array}$ & $\begin{array}{l}\text { 搨 } \\
\text { 官 }\end{array}$ & 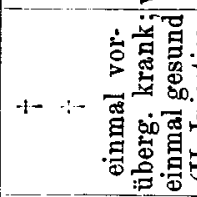 & 惑 & $\begin{array}{l}\exists \\
\$ \\
\$\end{array}$ \\
\hline $\begin{array}{l}\vec{z} \\
\dot{z}\end{array}$ & 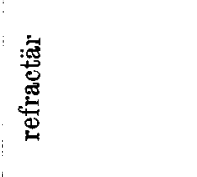 & $1^{1-}$ & $1+$ & 1 & $\begin{array}{l}\vec{B} \\
\dot{\Sigma}\end{array}$ & 密 & 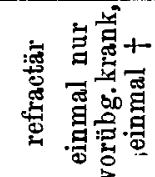 & \\
\hline $\begin{array}{l}\exists \\
\dot{\Xi}\end{array}$ & 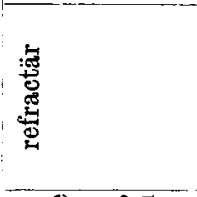 & $1+$ & 1 密 & 1 & $\begin{array}{l}\vec{x} \\
\dot{x}\end{array}$ & +1 密 & 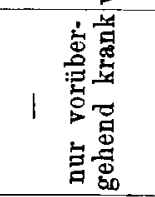 & 1 \\
\hline $\begin{array}{l}\exists \\
\dot{z}\end{array}$ & 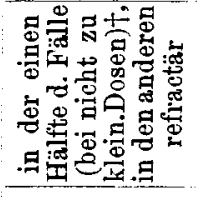 & ++ & 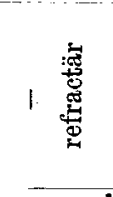 & 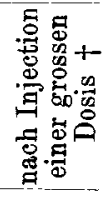 & $\begin{array}{l}\not \\
\dot{z}\end{array}$ & 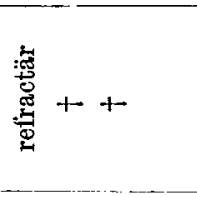 & 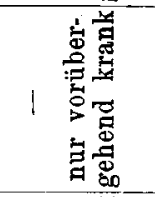 & 1 \\
\hline 棺 & 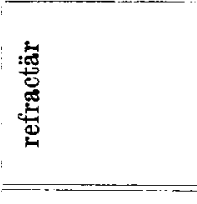 & ++ & 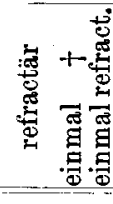 & 1 & $\begin{array}{l}\Delta \\
\dot{\alpha}\end{array}$ & 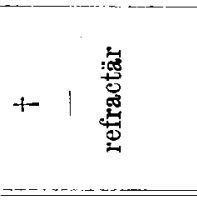 & 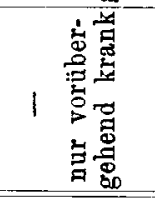 & ! \\
\hline & 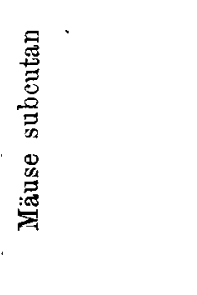 & 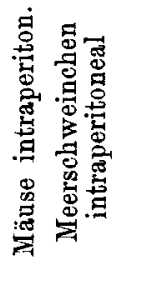 & 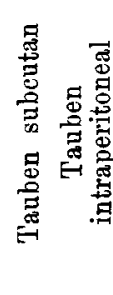 & 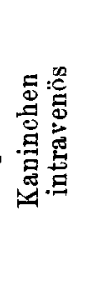 & & 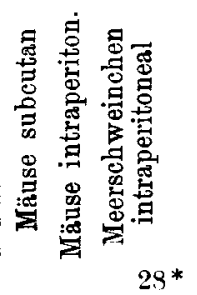 & 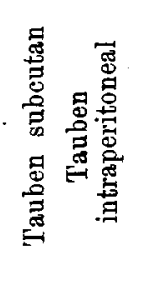 & 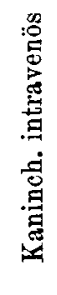 \\
\hline
\end{tabular}


des Unterhautgewebes führte, der die Thiere schliesslich erlagen. Die inoculirten Kapseldiplokokken fanden sich im ganzen Bereiche des Krankheitsherdes vor, während sie in den inneren Organen nur spärlich vertreten waren. Ebenso ruft der „Nekrosebacillus“ von Bang, ${ }^{1}$ auf Mäuse subcutan verimpft, progressive Nekrose hervor. Auch für die Entstehung der Herderkrankung der Leber ist keineswegs eine „specitische" Eigenschaft einer Bakterienart bezw. -Gruppe verantwortlich zu machen. Denn erstens ist diese Erscheinung nicht constanter Natur, sie findet sich in anscheinend regelloser Weise bald bei dem einen, bald bei dem anderen Vertreter der Mucosusgruppe, sowohl bei verschiedenartigem Infectionsmodus, als auch bei verschiedenen T'hierarten, und wird dann wieder unter gleichen Bedingungen vermisst. Zweitens aber werden die gleichen Effecte gelegentlich auch durch andere, nicht nur unter sich, sondern auch von unserer Gruppe verschiedene Mikroorganismen bewirkt. Nach den Mittheilungen der Litteratur, sowie nach unseren eigenen Erfahrungen können nekrotische Processe in der Leber ${ }^{2}$ einerseits durch verschiedene Batterienspecies bei verschiedenen Thierspecies (durch den Bacillus der Darmdiphtherie von Ribbert ${ }^{3}$ beim Kaninchen; durch den „Nekrosebacillus" von Bang beim Rinde; durch die Eberth'schen Bacillen" beim Dachs und Meerschweinchen; durch den „Phlegmonebacillus" von Ricker ${ }^{5}$ bei Mäusen), andererseits aber auch durch verschiedene Bakterienspecies bei der gleichen Thierspecies (durch Ricker's Bacillus, durch den „Bacillus mucosus capsulatus" bei Mäusen), und vice versa durch ein und dieselbe Bakterienspecies bezw. durch Varietäten dieser bei verschiedenen Thierspecies und -Classen (durch die Gruppe „Bacillus mucosus capsul.“ bei Mäusen, Meerschweinchen und Tauben) hervorgerufen werden. Und schliesslich vermögen Angehörige einer Bakteriengruppe die gleichen Veränderungen wie in der Leber, auch in anderen Organen zu verursachen (Nicolaier's Kapselbacillus in Nieren, Leber und Milz von Mäusen; Pfeiffer's Kapselbacillus in der Milz; Kockel's Kapselbacillus in der Niere von Mäusen).

Während somit die Erkrankung, welche die fraglichen Kapselbacillen bei den Versuchsthieren, Mäusen, Meerschweinchen und Tauben, erzeugen, nichts für diese Mikroorganismen Charakteristisches darbietet, kommt den

${ }^{1}$ Ref. in Baumgarten's Jahresbericht. 1892. Bd. VIII. S. 313.

2 Zellnekrosen in der Leber wurden bei Thieren auch nach Unterbindung des Ductus choledochus, nach Einführung von B. coli in diesen, sowie nach Injection von Pyocyaneusculturen in die Pfortader beobachtet.

3 Deutsche med. Wochenschrift. 1887. S. 141.

4 Virchow's Archiv. 1885. Bd. C. S. 23.

- Vgl. Fortschritte der Medicin. 1896. Bd. XIV. S. 449. 
Resultaten, welche durch die bei Hunden angestellten Fütterungsversuche erzielt wurden, eine ganz andere Bedeutung zu. Dieselben nehmen schon deshalb ein besonderes Interesse in Anspruch, weil bekanntlich Hunde sich bei Fütterung mit pathogenen Bakterien für eine grosse Anzahl derselben unempfänglich zeigen, die, per os genommen, bei anderen Thieren, speciell auch heim Menschen, pathogene Wirkung entfalten. Nur gegen den Einfluss der Proteusarten, welche ja auch für den Menschen pathogen sind und bei diesem unter Umständen Gastroenteritis verursachen können, sind diese Thiere sehr empfindlich. Auf eine Infection mit Proteusculturen reagiren Hunde mit einem Krankheitsbilde, welches dem beim Menschen gefundenen ähnelt.

Einen gleichen Befund haben wir auch bei dem, in einem Falle von Gastroenteritis acuta gezüchteten Mucosus XI zu verzeichnen. Durch das mit diesem angestellte Fütterungsexperiment wird die Thatsache bewiesen, dass die Infection mit einem Vertreter der Gruppe „Mucosus" vermittelst der Verdauungswege erfolgen kann, und zugleich wird es wahrseheinlich gemacht, dass ein Gleiches beim Menschen stattfindet. Das Resultat der Fütterung mit dem aus den tieferen Luftwegen bezw. aus Endocard. ulcer. cultivirten Mucosus XIII, sowie mit dem aus Ozaenasecret gezüchteten Kapselbacillus beweist auch für diese Arten ein ähnliches, wenngleich bedeutend schwächeres Wirkungsvermögen. Nur bei dem ganz jungen Thiere hatte die Infection mit dem „Ozaenabacillus" eine zwar schnell vorübergehende, so doch ausserordentlich heftige Erkrankung zur Folge. Im Uebrigen scheint aus unseren Versuchen an Hunden hervorzugehen, dass diese Thiere bei wiederholten Fütterungen mit der gleichen Bakterienart allmählich gegen den schädlichen Einfluss derselben unempfindlich werden, und dass diese durch "Gewöhnung" an eine Art erzeugte Immunität auch gegenüber der Einwirkung anderer, verwandter Arten Stand hält.

Aller Wahrscheinlichkeit nach lassen sich auch die bei den mit den verschiedenen Mucosusarten inficirten Mäusen, Meerschweinchen und Tauben stets beobachteten Veränderungen am Darmtractus nach der Richtnng hin verwerthen, dass der "Bacillus mucosus capsulatus", gleich wie er bei Thieren durch seine Gegenwart im Darmcanale, sei er vom Magen oder von der Blutbahn aus dorthin gelangt, eine Entzündung der Darmschleimhaut hervorruft, so auch beim Menschen Diarrhöen erzeugen kann.

Nach den Aufzeichnungen der Litteratur wurde ein gleicher Erfolg auch von anderen Autoren bei den mit Kapselbacillen der Gruppe „Mucosus" inficirten Thieren constatirt. So konnte u. A. Bordoni-Uffreduzzi mit seinem „Proteus hominis capsulatus" bei Mäusen, Meerschweinchen, Kaninchen und Hunden auf verschiedenartige Infectionsweise schleimige bezw. blutige Diarrböen erzeugen; bei Hunden trat ausserdem 
Brechreiz und Erbrechen auf. Durch die Section wurde in allen Fällen in dem katarrhalisch afficirten Dünndarm ein schleimartiger Inhalt gefunden, in dem die inoculirten Kapselbacillen stets in grosser Menge nachzuweisen waren.

Demnach können Angehörige der Gruppe „Bacillus mucosus capsulatus" mit grösster Wahrscheinlichkeit als ätiologisch bedeutsam für die acuten Durchfälle bezw. Brechdurchfälle des Menschen betrachtet werden. Bei dieser Annahme sind wir uns wohl bewusst, dass den Mucosusarten für diese Erkrankungen keinerlei ,specifische“ Bedeutung beigemessen werden darf. Die katarrhalischen Darmaffectionen zeigen, wie bekannt, eine derartige ätiologische Vielgestaltigkeit, dass für ihre Entstehung nicht constante Infectionserreger verantwortlich gemacht werden dürfen, sondern dass es vielmehr den Anschein hat, als ob verschiedene Darmbakterien, sowohl obligate wie facultative, gelegentlich im Stande sind, die genannten Processe hervorzurufen, während sie unter gewöhnlichen Verhältnissen unschädliche Bewohner des Darmcanales sind. Dieser Wechsel der Virulenz, welcher unter bisher noch unbekannten Bedingungen eintritt, ist 2. B. für das Bacterium coli commune hinlänglich sichergestellt worden. $\mathrm{Zu}$ den pathogenen Bakterien, welche gelegentlich entzündliche Darmkrankheiten verursachen können, gehören u. A. die Proteusarten, die ja in normalen Stuhlgängen nicht vorzukommen pflegen, dagegen in diarrhöischen Entleerungen, besonders bei Fällen von Cholera nostras der Erwachsenen und der Säuglinge, sehr häufig anzutreffen sind. Das Gleiehe wie für die Proteusgruppe gilt für die Mucosusarten. Dieselben sind in mehreren Fällen von Enteritis bezw. Gastroenteritis acuta (s. auch den Nachtrag) im Stuhlgang gefunden worden, während sie nach Sistirung der Diarrhöen aus demselben verschwanden. Bei der mikroskopischen und eulturellen Untersuchung von zahlreichen normalen Fäces konnten sie niemals nachgewiesen werden; ebensowenig im normalen Darminhalt kindlicher und erwachsener Leichen. $\mathrm{Ob}$ die fraglichen Kapselbacillen die Fähigkeit haben, für sich eine Entzündung der Darmschleimhaut zu erzeugen, lässt sich nicht mit Sicherheit entscheiden. Wahrscheinlich ist der ätiologische Zusammenhang so zu deuten, dass die in den oberen Luftwegen vorhandenen oder mit der Nahrung eingeführten Bakterien in einen bereits entzündlich afficirten Darm gelangten und hier in dem durch Transsudation vermehrten und chemisch veränderten Darminhalt in Wucherung

NB. In dem einen der Fälle, bei welchem Bordoni-Uffreduzzi seinen Kapselbacillus beobachtete - es handelte sich um ein achtjähres Kind - fand sich hauptsächlich eine Erkrankung des Gastro-intestinaltractus (Erbrechen und Diarrhöe; bei der Section wurde ein sehr intensiver Darmkatarrh constatirt). 
geriethen und zu Zersetzungen bezw. zur Bildung von Toxinen Anlass gaben. Die Folge davon war dann die Auslösung eines Brechdurchfalles oder einer einfachen Diarrhöe.

In allerletzter Zeit haben wir unsere Aufmerksamkeit darauf gerichtet, das in den Fäces des Säuglings vorkommende, dem Pneumobacillus Friedländer sehr nahe stehende Bact. lactis aërogenes zu cultiviren, um es mit unseren, aus diarrhöischen Stuhlgängen gezüchteten Bacillen zu vergleichen. In zwei Fällen gelang es uns einmal, dasselbe im normalen Milchkothe nachzuweisen, und zwar fand es sich hier neben dem sehr reichlich vertretenen Bact. coli nur in äusserst spärlicher Menge. In mikroskopischer und cultureller Beziehung zeigte es ein durchaus gleiches Verhalten, wie unsere Bacillen. ${ }^{1}$ - Nach Escherich (23) ist dieses Bacterium ,constant, wenngleich in geringer Anzahl im Milchkothe, dagegen in grosser Zahl in den oberen Theilen des Dünndarmes ${ }^{2}$ bei Milchnahrung vorhanden,

1 Auf schräg erstarrtem Glycerinagar bildete sich schon nach 6 Stunden bei $37^{\circ}$ C. ein üppiger Belag, der nach 24 Stunden sich über den grössten Theil der Oberfläche ausgebreitet hatte and eine ausgesprochen feucht-schleimig-zerfliessliche, grauweisslich-glasige, exquisit fadenziehende Beschaffenheit und eine stark saure Reaction zeigte. Nach etwa 2 Tagen hatte der Belag eine derartig zähe Consistenz angenommen, dass er mit der Platinöse zu langen Fäden ausgezogen werden konnte; ein Theil der Culturmasse war in die Reagensglaskuppe hinabgerutscht und bildete hier mit dem Condenswasser eine starre, unbewegliche Masse. In Agarplatten erschienen nach 24 Stunden auf der Oberfläche linsengrosse, flachgewölbte, rundliche Colonieen, welche unter dem Mikroskope ein graugelbliches, undurchsichtiges Centrum und einen durchscheinenden, aus glänzenden Kügelchen zusammengesetzten Saum erkennen liessen. Im Gelatinestich war das Wachsthum ein annähernd nagelförmiges; die oberflächliche Ausbreitung beschränkte sich auf die Umgebung der Einstichöffnang. Gasbildung wurde in gewöhnlicher Gelatine nicht oder nur spärlich beobachtet; dagegen war sie eine lebhafte in Milchzuckergelatine, desgleichen im Agarstich mit Zusatz von Milchzucker, Rohrzucker, Glycerin oder ameisensaurem Natron. Zaweilen wurden reichliche Gasbïäschen auch in Milch, welche nach ca. 24 Stunden unter Sänrebildung zum Gerinnen gebracht wurde, und in Bouillon bemerkt (hier fand sich an der Oberfläche der Flüssigkeit ein am Reagensglase haftender, aus Bacillen bestehender Ring; die Reaction war alkalisch). In traubenzuckerhaltigen Nährböden traten gewöhnlich nur vereinzelte Gasblasen auf. Auf Kartoffeln bildete sich der für den Bac. Friedländer charakteristische Belag, der nach 24 Stunden oder erst später von mehr oder weniger reichlichen Gasblasen durchsetzt wurde. Die verschiedenen Culturen verbreiteten einen angenehm frischen, aromatischen Geruch. Morphologisch zeigte das Bacterium eine buchstäbliche Uebereinstimmung mit dem von Abel für den „Ozaenabacillus" angegebenen Verhalten. Doch fiel uns zuweilen am Ende oder mehr in der Mitte der Bacillen eine rundliche, ungefärbte Stelle auf. Das Vorhandensein einer Kapsel war nur bei der ersten und zweiten Generation, später nicht mehr zu constatiren.

${ }^{2}$ Gessner (24) fand im menschlichen Doodenum das Bacterium tholoeideum, welches mit dem Bacterium lactis aërogenes identisch ist (vgl. Mannaberg, Die 
während es im Meconium und, wie es scheint, auch im Fleischkothe fehlt"; einmal konnte es ron Escherich auch in roher Milch nachgewiesen werden. Escherich fand bei der Cultivirung desselben ein mit dem des Pneumobacillus identisches Wachsthum, das sich vor Allem auch in dem für den letzteren so charakteristischen Verhalten auf Kartoffel und im Gelatinestich aussprach. Auch Denys und Martin (25) konnten zwischen dem Bact. lactis aërogenes und dem Bact. Friedländer keine constanten Unterschiede, weder in Culturen noch im Thierexperiment, constatiren, weshalb sie beide Bakterienarten als Varietäten derselben Species betrachten. Acceptiren wir diese Annahme als eine berechtigte, so stellt das Bact. lactis aërogenes nichts anderes dar, als den Pneumobacillus des Darmcanals, und das Vorkommen von pneumobacillenartigen Organismen im Dünndarminhalte des Säuglings hat nichts Auffallendes. Von diesem Gesichtspunkte aus betrachtet erscheint auch das Vorhandensein der gleichen Mikroben im diarrhöischen Stuhle der Erwachsenen erklärlich. Für beide Altersclassen muss als Ausgangspunkt der Infection die Mundhöhle, möglicherweise auch die Nahrung in Betracht gezogen werden, zumal in einigen unserer Fälle die Darmkrankheit nach dem Genuss von roher Milch aufgetreten ist.

Bei dieser Gelegenheit wollen wir unserer Ueberzeugung Ausdruck geben, dass den pneumobacillenartigen Mikroorganismen des Darmes, sc. dem Bact. lactis aërogenes, ebenso wie für die infectiöse Gastroenteritis der Erwachsenen, auch für den gleichen Krankheitsprocess der Säuglinge, die Cholera infantum, eine gewisse ätiologische Bedeutung zukommen kann. Wird diese auch vorwiegend als eine secundäre, ${ }^{1}$ in der Verschlimmerung einer an sich leichten und schnell vorübergehenden Störung der Darmfunctionen bestehende sein, so ist es doch auf der anderen Seite nicht

Bakterien des Darmes. Specielle Pathologie und Therapie von Nothnagel, 1895, Bd. XVII, S. 38). Dieser Autor konnte gleichfalls constatiren, dass das genannte Bacterium im Dünndarm gegenüber dem Bacterium coli weitaus vorwiegt, und dass im Dickdarm das Umgekehrte der Fall ist. - van Pateren (Ref. in Baumgarten's Jahresbericht, 1888, Bd. IV, S. 465) fand das Bacterium lactis ärogenes im Mageninhalt bei Säuglingen (bei Ammennahrung in 37.6 Proc.; bei Kuhmilchnahrung in 45.4 Proc.). - Nach Booker (Ref. in Baumgarten's Jahresbericht, 1888, Bd. IV, S. 467) nimmt das Bacterium coli commune in den diarrhöischen Entleerungen gegenüber den normalen entschieden proportional der Schwere der Erkrankung ab, während im Gegentheil ein dem Bacterium lactis aërogenes überaus ähnliches bezw. mit ihm identisches Bacterium an Menge bedeutend zunimmt.

${ }^{1}$ Baginsky (Deutsche med. Wochenschrift, 1888) weist darauf hin, dass das Bacterium lactis aörogenes durch zu starke eigene Vermehrung und damit verbundene Ueberproduction von Säure theils die Darmwandungen reizen, theils sich selbst vernichten könnte. 
von der Hand zu weisen, dass die mit den fraglichen Bakterien inficirte und durch deren Thätigkeit veränderte Milch, zumal dies in einer für das Auge unmerklichen Weise möglich ist, die alleinige Ursache für die Entstehung der Darmerkrankung bilden kann. Zu dieser Pathogenität befähigt die Bacillen vor Allem ihre energische Gährwirkung, welche sie auf die im Darminhalte vorhandenen Stoffe, in erster Linie den Milchzucker, ${ }^{1}$ auszuüben vermögen, und zwar ganz besonders deshalb, weil sie diese Fähigkeit in intensiver Weise auch bei anaërober Züchtung haben. Im eatarrhalisch afficirten Darmeanale, wo ihnen in Folge einer krankhaften Störung der Resorption und Peristaltik, sowie auf Grund einer reichlichen Secretion und Transsudation im ganzen Verlaufe gährfähige Stoffe zur Verfügung stehen, und wo sie zugleich in der Bethätigung ihrer Vitalität durch den reichlicher vorhandenen Sauerstoff begünstigt werden, ${ }^{2}$ werden sie daher ihre Gährthätigkeit in einer für den Organismus schädlichen Weise ausüben können.

Welche Rolle haben nun die Kapselbacillen in den übrigen Fällen, in denen sie gefunden wurden, gespielt? Für die Ohreiterungen, für welche ja Bacillen rom Charakter der Friedländer'schen wohl mit Sicherheit als Infectionsagens angesehen werden dürfen, kommt ihnen in unseren Fällen jedenfalls nur eine secundäre Bedeutung zu; denn stets wurden neben ihnen die „obligaten" Erreger dieses Processes (Diplococcus Fraenkel; Streptococcus pyogenes; Staphylococcus pyogenes aureus) nachgewiesen. Das Gleiche gilt für den im Kieferhöhlenempyem gefundenen Bacillus. Auch für die Erzeugung der Bronchitis und der ulcerösen Endocarditis können die Kapselbacillen aller Wahrscheinlichkeit nach nicht verantwortlich gemacht werden. In dem betreffenden Falle erscheint die Annahme naheliegend, dass die aus der Mundhöhle in die Bronchien eingewanderten Mikroben nur secundäre Eindringlinge waren, welche von da ins Blut gelangten, um schliesslich an den vorher durch Einnistung pyogener Kokken erkrankten Klappen fixirt zu werden.

Ziehen wir den Schluss aus unseren Beobachtungen und Erörterungen, so können wir folgende Sätze aufstellen:

1. Der „Bacillus mucosus capsulatus“, dessen Prototyp der Bacillus pneumoniae ist, repräsentirt eine Gruppe von Bacillen, welche trotz bemerkenswerther Verschiedenheiten ${ }^{3}$ als zusammengehörige Varietäten einer Species, des Bacterium Friedländer, zu betrachten sind.

${ }^{1}$ Nach Escherich (a. a. O. S. 175) giebt es kaum eine Bakterienart, die auf Milchzucker anaërob eine energischere Gährthätjgkeit ausübt als das Bacterium lactis aërogenes.

${ }^{2}$ Vgl. Escherich (a. a. O. S. 176).

${ }^{3}$ Wir möchten an dieser Stelle hervorheben, dass wir der Ansicht sind, es sei für die einzelnen Mucosusarten das Bestehen ähnlicher Verschiedenheiten anzanehmen, 
2. Die Verschiedenheiten, welche sich in cultureller Beziehung vornehmlich im Wachsthum auf Kartoffel, in thierexperimenteller in der Wirkung auf Mäuse bei subeutaner Infection kundgeben, sind zwar constanter Natur bei den einzelnen Arten, doch keineswegs „specifisch" für diese; denn selbst die auffallendsten Eigenthümlichkeiten der einen Art können auch bei der anderen beobachtet werden.

3. Die verschiedenen Vertreter der Gruppe lassen sich in zwei Classen einreihen, welche die im culturellen und thierpathogenen Verhalten einander ähnlichsten Arten umfassen. Der Hauptvertreter der einen Classe ist der Bacillus pneumoniue Friedländer, der der anderen der bei Ozaena sich findende Kapselbacillus. Dieser stellt jedoch nur eine durch veränderte Lebensbedingungen geschaffene Modification jenes, keine eigentliche Artverschiedenheit dar. In der Mitte zwischen beiden stehen Arten, welche, obgleich ihren sonstigen Eigenschaften nach zu der einen Classe gehörig, doch das eine oder das andere der für die Differenzirung wichtigsten Nerkmale der anderen Classe zeigen.

4. Der sogen. „Ozaenabacillus" ist also identisch mit dem Bacillus pneumoniae Friedländer und kann wie dieser an den verschiedensten Localitäten gefunden werden, ohne dass irgend eine "specifische" Affection zu bestehen braucht, um eine Erklärung für seine Gegenwart abzugeben.

5. Kapselbaoillen rom Charakter des Bakterium Friedländer sind in der gesunden Mund- und Nasenrachenhöhle verhältnissmässig selten und zumeist nur spärlich anzutreffen. Dies gilt besonders da, wo die Bacillen durch das Culturverfahren constatirt werden sollen, während ihr mikroskopischer Nachweis (NB. nur der negative Ausfall der Gram'schen Färbung schützt vor einer Verwechselung mit dem Pneumococcus!) nach den Angaben der Litteratur weit häufiger zu gelingen scheint. Die normale Beschaffenheit der Sehleimhaut und des von ihr gelieferten Secretes, welches zugestandenermassen einen wenig günstigen Näbrboden für Bakterien abgiebt und möglicher Weise sogar eine baktericide Wirkung ausübt, hindert eine Vermehrung der eventuell vorhandenen pneumobacillenartigen Mikroorganismen. Daher ist es sehr wohl möglich, dass die nur spärlich im normalen Secrete vertretenen Mikroben im mikroskopischen Präparate übersehen, oder selbst wenn sie hier gefunden werden, auf Grund eines verlangsamten und atypischen Wachsthums auf den gebräuchlichen

wie sie z. B. zwischen Bacterium coli und Typhusbacillus, zwischen cholerä̈hnlichen Vibrionen und Kommabacillus existiren. - Möglicher Weise wird es später gelingen, mit Hülfe der von Pfeiffer für die Cholera- und Typhusbacillen zur sicheren Erkennung derselben gefundenen Serumreaction die Gruppe der Kapselbacillen noch schärfer zu differenziren. 
Nährböden, die Folge des Aufenthaltes unter unvortheilhaften, ja schädlichen Lebensbedingungen, nicht in ihrer Eigenschaft erkannt werden können.

6. Dass ein pathologisch verändertes Secret einen bedeutend passenderen Nährboden für die verschiedensten Mikroorganismen darstellt, als ein normales, ist durch Untersuchungen sichergestellt worden. Aus diesem Grunde findet denn auch im chemisch veränderten Inhalt der Körperhöhlen eine üppige Vermehrung der normaler Weise in ihnen vorhandenen oder gelegentlich in sie hineingelangten Mikroben statt, wobei naturgemäss derjenige Organismus prädominirt, welcher die besten Bedingungen für sein Gedeihen vorfindet. So kann z. B. das sonst im normalen Intestinaltractus des Erwachsenen fehlende oder nicht zur Entwickelung gelangende Bacterium Friedländer, sc. Bacterium lactis aërogenes, in dem aus anderen Ursachen katarrhalisch afficirten Darmcanale in Wucherung gerathẹ und die Bewohner des normalen Darminhaltes mehr oder weniger vollständig verdrängen. Später aber, wenn eine Rückkehr zur Norm stattfindet, werden wieder die früheren Verhältnisse Platz greifen. Ein Gleiches gilt auch für andere Bakterien, obligate wie gelegentliche, nicht nur des Darmcanales, sondern der verschiedensten Localitäten des menschlichen Körpers. - Wie nun im Gegensatz zum normalen die Bakterienflora in manchen pathologischen Nasensecreten viel üppiger entwickelt ist, so hat es nichts Auffallendes an sich, dass dies ganz besonders in dem so ausserordentlich zersetzungsfähigen Secrete bei Ozaena der Fall ist. Und dass hier ausser den mannigfachsten sonstigen Keimen vorwiegend ein Bacillus gedeiht, welcher durch sein plumpes und die denkbar geringsten Anforderungen an den Nährboden stellendes Wachsthum vor allen anderen Bakterienarten ausgezeichnet ist, kann als nichts Wunderbares gelten. Sein vorwiegendes Vorkommen in den der Schleimhaut direct aufliegenden, von Borken bedeckten Schleimmassen wird durch sein Vermögen, auch bei Luftabsehluss gut zu gedeihen, und durch sein besseres Fortkommen in feuchten Medien hinreichend erklärt. In dem oberflächlichen, zu festen Krusten eingetrockneten Secrete wird er weniger reichlich anzutreffen sein, einerseits weil er hier mit zahlreichen anderen Mikroben, welche zu einem gedeihlichen Fortkommen der Luftzufuhr bedürfen, concuriren muss, und andererseits, weil ihn hier eine gewisse Empfindlichkeit gegen Eintrocknung an einer üppigen Entfaltung hindert. Dass aber der bei Ozaena nachgewiesene Kapselbacillus nicht ausschliesslich an die Ozaenanase gebunden ist, dafür spricht das Vorkommen von „Ozaenabacillen“ an den verschiedensten Localitäten des Körpers ohne das gleichzeitige Bestehen eines ozaenaartigen Processes [normale Nebenhöhlen (E. Fraenkel); Mittelohr, Bronchialschleim, Endocarditis (vgl. Text)]. 


\section{Nach t rag.}

Nach Abschluss der vorliegenden Untersuchungen wurden noch in drei Fällen Mucosusarten gefunden, und zwar:

\section{a) Bei Gastroenteritis acuta.}

Fall 15, Wendt, 58 Jahre alt, Wärterin, erkrankte am 3./VII. Morgens plötztlich unter heftigem Erbrechen, Durchfall, Wadenkrämpfen und Ohnmachtsgefühl. Nach einigen Stunden liessen Durchfall und Erbrechen etwas nach. Am 3./VII. Nachm. Stuhl dünnflüssig, wie rahmartiger Eiter aussehend, sehr reichlich Schleim enthaltend, übelriechend. Reaction alkaliseh. Im gefärbten Deckglaspräparat sehr reichliche Mikroorganismen; wenig mannigfache Formen (kokkenähnliche Gebilde und kurze, sowie längere, plumpe Stäbchen, die zum grossen Theile mit einer deutlichen, breiten Kapsel versehen waren); ausserdem sehr zahlreiche Rundzellen. Auf Glycerinagarplatten (Ausstrich aus Peptonwasser nach einfacher Aufschwemmung bezw. mehrstündiger „Anreicherung") vorwiegend Bact. coli, vereinzelte Colonieen von Bacillus mucosus capsulatus (XV). Desgleichen in Gelatineplatten. - Am 4., 5. und 6./VII. Stuhl angehalten, vom 7./VII. ab dauernd geformt.

Fall 16, Klose, 16 jähr. Arbeiterin, erkrankte am 4./VIII. plötzlich ohne nachweisbare Ursache an krampfartigen Magenschmerzen, Erbrechen und Durchfall. Am 8./VIII. Stuhl sehr reichlich, dünnflüssig, mit gröberen Kothpartikeln und mit Kothballen untermischt, von dunkelbrauner Farbe, fäculentem Geruch und alkalischer Reaction. Im mikroskopischen Präparat enorm zahlreiche Mikroben; sehr mannigfache Formen (vorwiegend pleomorphe Bacillen, z. Th. von einer deutlichen Kapsel umgeben). Auf Glycerinagarplatten (Ausstrich aus einer Kothaufschwemmung in Peptonwasser) vorwiegend Bact. coli, vereinzelte Colonieen von Bacillus mụcosus capsulatus (XVI). Desgleichen in Gelatineplatten. Am 9./VIII. Stuhl geformt; Wohlbefinden.

NB. In beiden Fällen handelte es sich um kräftige, früher stets gesunde Personen, bei denen keine sonstige Erkrankung constatirt, insbesondere das Bestehen einer Ozaena ausgeschlossen werden konnte.

\section{b) Bei Endocarditis ulcerosa.}

Fall 17, Völcker, 37 Jahre alter Mann. Section am 24./VII. Anatomische Diagnose: Septicopyämie (Endocarditis ulcerosa der Aortaklappen; multiple Abscesse in den Nieren; Infectionsmilz). Die culturelle Untersuchung (Ausstrich auf Glycerinagarplatten) ergab aus der Milz Reincultur von Streptococcus pyogenes, aus der ulcerirten Aortaklappe sehr zahlreiche Colonieen von Streptococcus pyogenes und ebenso reichliche eines pleomorphen Kapselbacillus, der in Gestalt von üppigen, grauweisslichen, schleimigen Auflagerungen wuchs. In letzteren war hier und da eine Gasblase oder eine cen. trale Delle nachweisbar (Bacillus mucosus capsulatus XVII). 
Bei der Cultivirung auf den verschiedenen Nährböden zeigten die in diesen drei Fällen gezüchteten Kapselbacillen ${ }^{1}$ ein durchaus identisches Verhalten.

In dem in Petrischälchen ausgegossenen Glycerinagar erschienen nach 24 Stunden in der Tiefe theils stecknadelkopfgrosse, hellgelbliche, undurchsichtige, rundliche, ovale oder wetzsteinförmige Colonieen (mikroskop. hell- oder dunkelgelb-bräunlich, feingranulirt oder homogen; Rand scharf, glatt oder unregelmässig gekerbt), theils etwas grössere, grauweissliche, durchscheinende, kreisrunde Colonieen, die sich mikroskopisch ähnlich wie die oberflächlichen verhielten. Letztere waren auf der weniger dicht bewachsenen Platte bis linsengross, flach gewölbt, kreisrund, scharf- und glattrandig (mikroskopisch zarter, scharfer, etwas gezackter Rand; fein granulirtes, aus kleinsten, dichtstehenden, glänzenden Kügelchen zusammengesetztes Gefüge. Durchscheinendes graugelbliches Centrum; durchsichtiger wasserheller Saum. Central oder excentrisch zuweilen eine kleine, dunkel gefärbte, undurchsichtige Colonie. Bei den grossen Colonieen erstreckten sich häufig vom dunkleren Centrum aus strahlige Fortsätze von gleicher Färbung in den helleren Saum). Geruch der Platte angenehm friseh, aromatisch.

Auf schräg erstarrtem Glycerinagar (schon nach 6 Stunden üppiges Wachsthum) nach 24 Stunden bei $37^{\circ}$ dicker, über den grössten Theil der Oberfläche ausgebreiteter, gleichmässig erhabener, ausgesprochen feuchtschleimiger (nicht fadenziehender) Belag mit unregelmässig gebuchteten Rändern. Farbe im auffallenden Lichte grauweisslich-glasig, im durchfallenden hellgelblich. Condenswasser intensiv getrübt, dünnflüssig (wird allmählich dünn- bezw. dickschleimig); Reaction desselben, ebenso des Belages, stark sauer. Geruch der Cultur aromatisch, zuweilen etwas fötide. Bei Zimmertemperatur gleiches, nur nicht gauz so üppiges Wachsthum.

Im Ameisenagarstich oberflächlich dünner, grauweisslicher, feuchtglänzender Beschlag; breiter, bis in die Tiefe reichender Impfstich, Ränder glatt oder mit regelmässigen, kleinen, kolbenartigen Fortsätzen versehen.

Im Traubenzuckeragarstich auf der Oberfläche eine linsengrosse, rundliche, flachgewölbte, scharfrandige, grauweissliche Colonie. In Bouillon diffuse Trübung; an der Oberfläche der Flüssigkeit zuweilen ein ringförmiger Beschlag des Glases; etwas grauweisslich-gelblicher Bodensatz, der beim Schütteln in Form von Fäden und Flocken aufsteigt und sich

1 In morphologischer Beziehung haben die früher gemachten Angaben auch fïr diese Bacillen Geltung. Nur schien es, als ob bei ihnen gerade auf künstlichem Nährboden (sowohl bei $37^{\circ}$ als auch bei Zimmertemperatur) die Kapsel häufiger und in schönerer Ausbildung als im Thierkörper zu finden sei. 
schnell in der Flüssigkeit gleichmässig vertheilt. Reaction alkalisch. Keine Indolreaction.

Milch wird nach 1 bis $2 \times 24$ Stunden zur feinflockigen Gerinnung gebracht. Reaction stark sauer, auch bei der nach 24 stünd. Aufenthalt im Brutschrank unverändert gebliebenen Nährflüssigkeit. Kein specifischer Geruch.

Im Gelatinestich nach 24 Stunden oberflächlich eine linsengrosse, flachgewölbte, rundliche, mattweissliche Colonie, die sich nach weiteren 24 Stunden vollständig abflacht; im ganzen Bereiche des Impfstiches bandartiges Wachsthum. Keine Gasbildung.

Auf Kartoffel üppiger, gleichmässig erhabener, hellgelblicher, theils feuchtschleimiger, theils wachsartig glänzender Belag mit gezackten Rändern. Farbe der Kartoffel unverändert oder graugelblich. Nach einiger Zeit wird der Belag ausgesprochen rahmartig-zerfliesslich.

Bei Mucosus XV und XVII lebhafte Gasbildung auf Kartoffel, in Glycerinagar (Strich und Stich), desgleichen in Ameisenagar; geringe in Traubenzuckeragar und in den bei Zimmertemperatur gehaltenen Culturen. Bei Mucosus XVI nur geringe Gasbildung in den verschiedenen Medien; dieselbe stellt sich bei den Culturen auf Kartoffeln gewöhnlich erst nach 48 stündiger Züchtung bei $37^{\circ}$ ein.

\section{Thierexperimente.}

Weisse Mäuse, subcutan an der Schwanzwurzel geimpft.

Mucosus XV:

Maus 1, grosse Oese einer 24 std. Agareultur, 6./VII. dauernd gesund. Mucosus XVI:

Maus 1, mittelgrosse Oese, 12./VIII. desgl.

Mucosus XVII:

Maus 1, mittelgrosse Oese, 11./VIII. desgl.

Am 12./VIII. wird eine Maus mit einer kleinen Oese einer 24 stünd. Agarcultur von Mucosus XVII intraperitoneal inficirt. Mehrere Stunden darauf macht das Thier einen schwerkranken Eindruck, sitzt mit gesträubtem Fell und zusammengekniffenen Augenlidern da, zeigt beschleunigte Athmung. Am 13./VIJI. ist es etwas munterer, läuft zuweilen im Käfig umher; Athmung ruhiger; Fell gesträubt; Augen anhaltend geschlossen. Am After zeigt sich eine hellgelbliche, ausserordentlich zähschleimige Masse, aus welcher nach Ausstrich anf Agarplatte der eingeimpfte Kapselbacillus nahezu in Reincultur gezüchtet wird. - Am 15./VIII. hat das Thier sich vollständig erholt und bleibt dauernd gesund.

Am 14./VIII. wird einer zweiten Maus eine kleine Oese einer 24 stünd. Agarcultur des Mucosus XVII (I. Uebertragung des aus den schleimigen 
Fäces gezüchteten Materials) intraperitoneal einverleibt, + nach 12 Stunden. Sectionsbefund: Geringe Injection des Peritoneums; kein Peritonealexsudat. Organe der Bauchhöhle geschwollen, blutreich. Milz stark vergrössert; auf der Oberfläche zahlreiche, punkt- bis stecknadelkopfgrosse, rundliche, grauweisse Herde. Pleurahöhlen leer; Lungen gebläht. Herzhöhlen mit dunkelrothem, dünnflüssigem Blute strotzend gefüllt. Etwas fadenziehender Beschlag auf Därmen und Lungen. Schwellung und Hyperämie der Inguinaldrüsen. Am After, sowie im ganzen Bereiche des Darmcanales zähschleimige, stark fadenziehende, hellgelbliche Massen. NB. In jeder Uterushälfte fanden sich zwei nahezu ausgetragene Föten vor. In Paraffinschnitten, welche durch Fötus und Placenta zugleich gelegt waren, konnten Bacillen nur im mütterlichen Theile der Placenta constatirt werden.

Im Herzblut (hier keine Kapselbildung) und Milzsaft (hier nur z. Th. deutliche Kapsel) waren die injicirten Bacillen mikroskopisch und culturell in Reincultur nachweisbar.

Meerschweinchen, mit einer grossen, in $1^{\mathrm{ccm}}$ Bouillon aufgeschwemmten Oese einer 24stündigen Agarcultur intraperitoneal inficirt.

Mucosus XVII:

Meerschweinchen 1, 1.1./VIII. - bleibt vollständig munter.

Meerschweinchen 2, eine grosse Oese der aus Fäces gezüchteten Cultur, 14. VIII., † nach ca. 12 Stunden. Ziemlich reichliches, trüb-gelbbräunliches, etwas fadenziehendes Exsudat (enorm zahlreiche Bacillen ohne Kapsel; ganz spärliche Leukocyten). Lebhafte Injection des Peritoneums und der Darmserosa. Organe der Bauchhöhle, besonders die Milz, gross, blutreich. Leberoberfläche dicht besät mit kleinen, bis stecknadelkopfgrossen, rundlichen, grauweisslichen bezw, gelbbräunlichen Knötchen. Pleurahöhlen leer; etwas fadenziehender Beschlag auf den stark geblähten Lungen, die theilweise frische Infarktbildungen erkennen lassen. Beide Herzhöhlen mit flüssigem, dunkelrothem Blute prall gefüllt. Im Dünndarm zähschleimiger Inhalt.

Mikroskopisch im Herzblut vereinzelte Bacillen ohne Kapsel, im Milzsaft (hier grösstentheils breite Kapsel) und Pleurabeschlag (hier ohne Kapsel) sehr zahlreiche Bacillen, desgleichen im spärlichen, schleimigen Inhalt der Gallenblase (hier bei der Mehrzahl deutliche Kapsel). Ueberall finden sich die Bacillen, sowohl in gefärbten Deckglaspräparaten, als auch im Ausstrich auf Agarplatten, in Reincultur.

Mucosus XV:

Meerschweinchen 1, 13./VIII., † nach 18 Stunden. Sectionsbefund: Lebhafte Injection des Peritoneums; mässig reichliches, trüb-hellgelbliches, dünnflüssiges, etwas fadenziehendes Exsudat [mikroskopisch enorm reichliche, z. Th. mit deutlicher Kapsel versehene Bacillen; sehr zahlreiche, kürzere und längere, gerade und gekrümmte (einfach oder in Zickzackform mit abgerundeten Ecken gebogene) Fäden. Spärliche Leukocyten]. Etwas schleimicreitriger Belag auf der Leberoberfläche. Milz vergrössert, sehr blutreich (mikroskopisch im Milzsaft sehr reichliche Bacillen, z. Th. von einer schönen, breiten Kapsel umgeben). Spärliches, ziemlich klares, dünnflüssiges Exsudat in beiden Pleurahöhlen (mikroskopisch reichliche Bacillen ohne Kapsel; zahl- 
reiche grosse Epithelien und spärliche Leukocyten). Lungen stark gebläht, blutreich. Im rechten Ventrikel frisch geronnenes Blut, in dem mikroskopisch wenig reichliche Bacillen ohne deutliche Kapsel nachweisbar sind. - Ausstrich des Peritonealexsudates auf Agarplatte ergiebt schon nach 6 Stunden einen üppigen, confluirten, grauweisslich-glasigen, ausgesprochen schleimigen (nicht fadenziehenden) Belag von angenehmem Geruch. Auch auf der mit Herzblut beschickten Agarplatte ist bereits nach 6 Stunden ein deutliches Wachsthum zu constatiren (Belag hier zarter, nur z. Th. confluirt, im Uebrigen aus punkt- bis stecknadelkopfgrossen, glasigen Colonieen bestehend). Nach 24 Stunden üppiger Belag wie vorher. Auf beiden Platten Mucosus in Reincultur. Im Duodenum, dessen Schleimhaut intensiv geröthet ist, dünnschleimiger, hellgelblicher, mit reichlichen Gasblasen vermischter Inhalt. Magenschleimhaut mässig stark injicirt; der im Magen befindliche Speisebrei ist von einer dicken, zähen Schleimmasse eingehüllt. Im Darminhalt, sowie im Magenschleim mikroskopisch reichliche, z. Th. gekapselte Stäbchen.

Mucosus XVI.

Meerschweinchen 1, 13./VIII, † nach ca. 18 Stunden. Reichliches, trübgelbbräunliches, dünnflüssiges, nicht fadenziehendes Exsudat. Auf der Leberoberfläche vereinzelte stecknadelkopfgrosse, rundliche Herde von graugelblicher Farbe. Lungen gebläht, ohne vermehrten Blutgehalt. Dünndarminhalt frei von Gasblasen. Im Uebrigen Befund wie vorher.

Die aus Meerschweinchenkörper gezüchteten Culturen des Muc. XVI zeigen auf Agarplatten theils geringe (Herzblut), theils lebhafte Gasbildung (Peritonealexsudat); letztere findet sich auch bei weiteren Uebertragungen auf schräg erstarrtem Agar.

In den direct aus Thierkörper gewonnenen Agarculturen lassen die Bacillen beim Mucosus XV und XVI nur theilweise deutliche Kapselbildung erkennen; beim Mucosus XVII (Ausstrich der schleimigen Fäces der intraperitoneal geimpften Maus) sind sie zum grössten Theile mit einer schönen, breiten Kapsel versehen; in gefärbten Deckglaspräparaten zeigt sich ein feines, regelmässiges, wohlausgebildetes Netzwerk mit rundlichen oder ovalen Maschen, die theils leer, theils mit Bacillen gefüllt sind; eine ähnliche schöne Ausbildung der Kapseln findet sich bei der weiteren Uebertragung auf Agar, doch ist das Netzwerk hier nicht ganz so gleichmässig und deutlich. In der zweiten Generation zeigen Mucosus XV und XVI durchweg deutliche Kapseln, deren Contouren in gefärbten Deckglaspräparaten grösstentheils zu einem bienenwabenartigen Gerüstwerk verschmolzen sind. Die zwischen den theils leeren, theils von je einem Bacillus eingenommenen Hohlräumen befindlichen Balken sind von zarter, homogener oder von breiterer, feinkörniger Beschaffenheit.

Mucosus XV, XVI und XVII gehören zu den mit dem Bacillus Friedländer identificirten Kapselbacillen der Gruppe „Bacillus mucosus 
capsulatus". Der Mucosus XVII, welcher zu Anfang eine weniger virulente Varietät der übrigen darzustellen schien, ist den letzteren nach Passage durch den Thierkörper auch im pathogenen Verhalten gleichwerthig geworden. Während diesem wohl kaum irgend ein Einfluss auf die Entstehung oder den Verlauf des Krankheitsprocesses, bei welchem er constatirt wurde, beigemessen werden kann, kommt dem Mucosus XV und XVI für die Gastroenteritis acuta die ätiologische Bedeutung zu, welche für die anderen, bei dieser Affection gefundenen Kapselbacillen in Anspruch genommen wird. 


\section{Litteratur.}

1. Friedländer, Die Mikrokokken der Pneumonie. Fortschritte der Medicin. 1883. Bd. I. S. 715.

2. Weichselbaum, Ueber die Aetiologie der acuten Lungen- und Rippenfellentzündungen. Wiener med. Jahrbücher. 1886. S. 483. (S. auch Baumgarten. I'athol. Mykologie. 1890. Bd. I. S. 243.)

3. Baumgarten. Lehrbuch der pathol. Mykologie. 1890. Bd. I. S. 244.

4. Pfeiffer, Ueber einen neuen Kapselbacillus. Diese Zeitschrift. 1889. Bd. VI. S. 145.

5. Mandry, Zur Kenntniss des Friedländer'schen Bacillus und einer Abart desselben. Fortschritte der Medicin. 1890. Bd. VIII. S. 205.

6. Passet. Untersuchungen über die Aetiologie der eitrigen Phlegmone des Menschen. Berlin 1885.

7. Baumgarten. Lehrbuch der pathol. Mykologie. 1890. Bd. II. S. 686.

8. Mori, Ueber pathogene Bakterien im Canalwasser. Diese Zeitschrift. 1888. Bd. IV. S. 47.

9. Bordoni-Uffreduzzi, Ueber den Proteus hominis capsulatus und über eine neue durch ihn erzeugte Infectionskrankheit des Menschen. Ebenda. 1888. Bd. III. S. 333 .

10. Kockel, Ueber einen dem Friedländer'schen verwandten Kapselbacillus. Fortschritte der Medicin. 1891. Bd. IX. S. 331.

11. Loeb, Ueber einen bei Keratomalacia infantum beobachteten Kapselbacillus. Centralblatt für Balteriologie. 1891. Bd. X. S. 369.

12. Fasching, Ueber einen neuen Kapselbacillus. Sitzungsberichte der Kaiser. Akademie der Wissenschaften in Wien. Mathem.-naturw. Classe. 1891. Bd. C. Abth.3. - Ref. im Centralblatt für Bakteriologie. 1892. Bd. XII. S. 304.

13. Paulsen, Mikronrganismen in der gesunden Nasenhöhle und beim acuten Schnupfen. Centralblatt für Bakteriologie. 1890. Bd. VlII. S. 344. - Derselbe, Ueber einen schleimbildenden Kapselbacillus bei atrophirenden Rhinitiden. Mittheil. für den Verein Schleswig-Holsteiner Aerzte. N. F. II. Jahrg. Nr. 1.

14. Abel, Bakteriologische Studien über Ozaena simplex. Centralblatt für. Bakteriologie. 1893. Bd. XIII. S. 161. - Derselbe, Die Aetiologie der Ozaena. Diese Zeitschrift. 1896. Bd. XXI. S. 89.

15. v. Dungern, Ein Fall von hämorrhagischer Sepsis beim Neugeborenen. Centralblatt für Balteriologie. 1893. Bd. XIV. S. 541.

16. Marchand, Ueber einen noch nicht näber bekannten Kapselbacillus. Sitzungsberichte der Gesellschaft zur Beförderung der gesammten Naturwissenschaft zu Marburg. 1893. Nr. 3. - Ref. im Centralblatt fïr Bakteriologie. 1894. Bd. XV. S. 428 . 
17. Nicolaier, Ueber einen neuen pathogenen Kapselbacillus bei eitriger Nephritis. Centralblatt für Bakteriologie. 1894. Bd. XVI. S. 601.

18. Wicklein, Chron. Leberabscess, verursacht durch einen Kapselbacillus (Bacillus capsulatus Pfeiffer?). Ebenda. 1895. Bd. XVIII. S. 425.

19. Wright u. Mallory, Ueber einen pathogenen Kapselbacillus bei Bronchopneumonie. Diese Zeitschrift. 1895. Bd. XX. S. 220.

20. Chiari, Ueber einen als Erreger einer Pyohämie beim Menschen gefundenen Kapselbacillus. Prager med. Wochenschrift. 1895. - Ref. im Centralblatt für Bahteriologie. 1895. Bd. XVIII. S. 288.

21. Kreibohm, Ueber das Vorkommen pathogener Mikroorganismen im Mundsecret. Dissertation. Göttingen 1889. (Cit. nach Flügge. Die Mikroorganismen. 1886. S. 260.)

22. Miller. Die Mikroorganismen der Mundhöhle. 1892. S. 320-322.

23. Escherich. Die Darmbakterien des Säuglings. Stuttgart 1886.

24. Gessner, Ueber die Bakterien im Duodenum des Menschen. Archiv für Hygiene. 1888. Bd. IX. S. 128.

25. Denys u. Martin. Ref. in Baumgarten's Jahresbericht. 1893. Bd. IX. S. 549. 